gOTR. ONTARIO MUSEUM 


\section{LIBRARY}

YAL ONTARIO MUSEUM

VIVERSITY OF TORONTO 100. QUEENS PARK

TORONTO 5, CANADA
GLENN B. WIGGINS

Centennial of Entomology in Canada 1863-1963

O Y A L O N T A R I O M U SEU M - U N I V ER S I T Y O F T O R O N T O
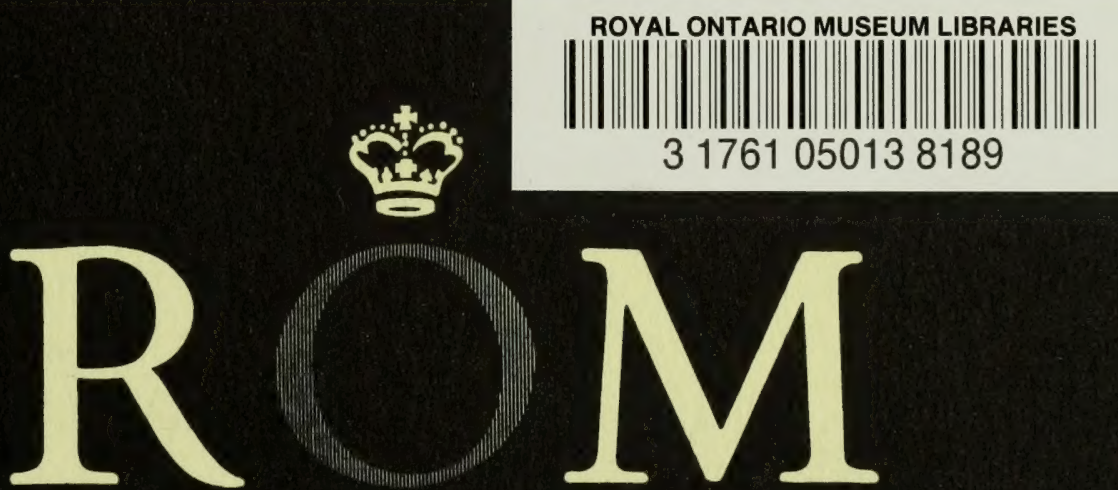
IIBRARY AUSEUM

ROYAI ONTARIO MUSONTO

UPRIV OSARK

TORONTO 5, CANADA. 


\section{CENTENNIAL OF ENTOMOLOGY}

IN CANADA 

Digitized by the Internet Archive in 2011 with funding from University of Toronto 


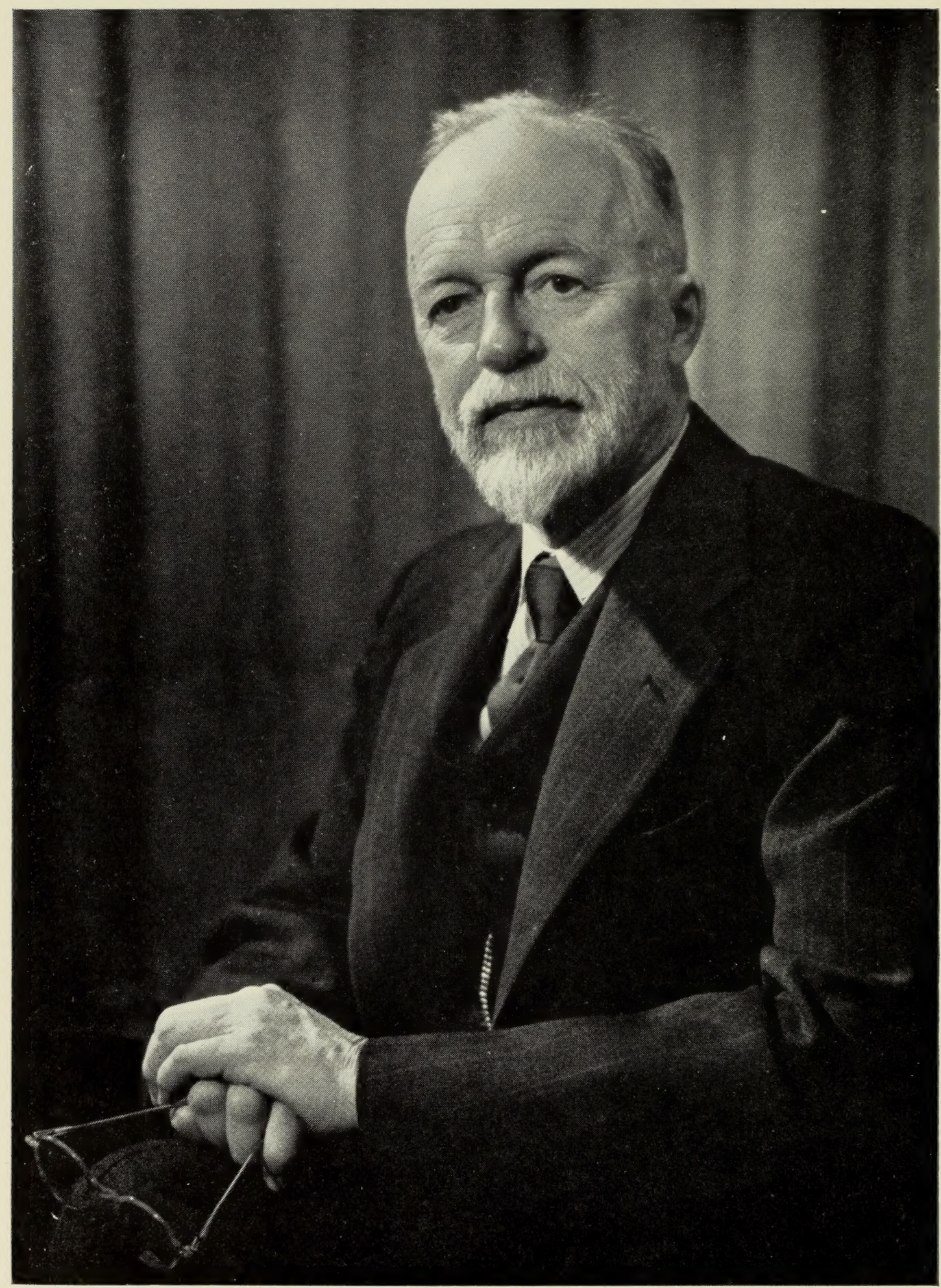

Professor Edmund M. Walker, B.A., M.B., D.Sc. (hon. causa), F.R.S.C. 


\section{Centennial of \\ Entomology \\ in Canada \\ 1863-1963}

A tribute to EDMUND M. WALKER

Edited by

GLENN B. WIGGINS

Contribution No. 69

LIFE SCIENCES

ROYAL ONTARIO MUSEUM UNIVERSITY OF TORONTO 
(C) University of Toronto Press, 1966

Printed in Canada 


\section{Contents}

Introduction, Glenn B. Wiggins 3

Entomology in Canada, G. P. Holland 7

Autobiographic Sketch, Edmund M. Walker 14

Professor of Zoology, J. R. Dymond 35

Curator, Royal Ontario Museum, Glenn B. Wiggins 43

Work on the Orthoptera, F. A. Urquhart 54

Grylloblatta, H. H. J. Nesbitt 62

The Study of Odonata, Philip S. Corbet 70

Impression of Delight, J. G. Oughton 79

Publications of Edmund M. Walker, Library Staff, Royal Ontario Museum 



\section{Contributors}

GLENN B. WIGGINS: Department of Entomology and Invertebrate

Zoology of the Royal Ontario Museum, University of Toronto G. P. HOLLAND: Director, Entomology Research Institute, Canada Department of Agriculture, Ottawa EDMUnd M. WALKer: Professor Emeritus, Department of Zoology; Honorary Curator, Royal Ontario Museum, University of Toronto

J. R. DYMOND (obiit): Professor Emeritus, Department of Zoology, Honorary Curator, Royal Ontario Museum, University of Toronto

F. A. URQUHART: Department of Zoology, Scarborough College, University of Toronto

H. H. J. NESBITT: Dean of Science, Carleton University, Ottawa PHILIP S. CORBET: Entomology Research Institute, Research Branch, Canada Department of Agriculture, Ottawa

J. G. OUGHTON: Department of Zoology, University of Guelph 

CENTENNIAL OF ENTOMOLOGY

IN CANADA 



\section{Introduction}

\section{GLENN B. WIGGINS}

THE CENTENNIAL of the Entomological Society of Canada was observed in 1963, marking the first one hundred years of organized entomology in this country. One of the events in observance of this occasion was a special exhibit, The Centennial of Entomology in Canada, 1863-1963, prepared in the Royal Ontario Museum and displayed in the Life Sciences galleries between April, 1963, and January, 1964. The exhibit was officially opened by Dr. George P. Holland on April 16, 1963, exactly one hundred years to the day after the founding meeting of the Society had been held in Toronto. The opening of the exhibit was attended by some one hundred guests, including representatives from the Entomological Society of Canada, the Entomological Society of Ontario, and from many of the universities and government stations in Ontario in which teaching and research in entomology are conducted.

Dr. Holland's opening address, printed in this volume, retraces the events leading to the meeting in Toronto at which the Society was founded. That the founding meeting was held at all (see Fig. 1), was almost entirely due to the enthusiastic interest in entomology of two young men, Charles Bethune, a student of Trinity College, Toronto, and William Saunders, a druggist of London, and of Professor Henry Croft of the University of Toronto. Biographical information for all three of these figures, as well as a more extensive account of the founding meeting and early days of the Society, have been published elsewhere. ${ }^{1}$ It is worth noting here, though, that Professor Croft, who became the first president of the Entomological Society of Canada, was a prominent figure in the life of the University of Toronto, distinguished among other things by his organization of the University 
Rifle Corps which participated in the skirmishes prompted by the Fenian Raids of 1866 , and ultimately by his tenure of the post of vice-chancellor of the University. Croft Chapter House, now a faculty common room in University College, was originally his chemical laboratory. ${ }^{2}$ Dr. Holland describes the activities of the Society during its early years, and how in fact, there came to be not one Society, but two, the Entomological Society of Ontario as well as that of Canada, which traced their origins to that meeting. The remarkable development of entomology in Canada during its first century is shown clearly in his address. In fact, its progress in entomology may well be one of this country's pre-eminent scientific achievements. This should not be surprising, because development in agriculture and forestry, both of tremendous importance in Canada, depends heavily upon knowledge about those insects which are destructive to man's endeavours. Although it was economic necessity which gave to entomology in Canada its momentum, the force which first put it into motion sprang largely from aesthetic interests. For those early members of the Society, insects were in themselves fascinating and beautiful creatures, and an appreciation of their rich diversity of form and habit gave at least some insight into the creative vitality, and yet the delicate subtlety, underlying the natural world. For all its modern trappings after a century of development in Canada, entomology has not lost for its students that deep sense of wonder about insects, nor the rewards of personal satisfaction when even some of them come to be understood a little better.

It was as a synthesis of the scientific and the aesthetic, against a background of the historical, that the Museum's exhibit undertook to portray Canadian entomology (see Fig. 2). During the ten months that the exhibit was on display, some quarter million persons visited the museum galleries; and the exhibit was also used for lectures about insects and their study to visiting school classes by teachers in the Museum's Department of Education. It is our hope that the exhibit did indeed help to enlarge society's understanding of entomology, for in a broader sense, this is what museum exhibition is all about.

Observance of this centennial in the University of Toronto was, then, for several reasons entirely appropriate. Prominent among these reasons was the fact that a central figure in all of the proceedings of the centennial was Dr. Edmund M. Walker, professor emeritus in

2An extensive account of Professor Croft's life and his activities in the University of Toronto was written by C. J. S. Bethune (1916): Canad. Ent. 48(1): 1-5. 
the University of Toronto. In both the University's Department of Zoology and its Royal Ontario Museum (for in much of his academic career his work as a professor was broadened to include that of a museum curator) Dr. Walker was the pioneer in entomology and invertebrate zoology. Through his research he earned the international reputation of a distinguished scholar, and brought recognition to the University in which he worked. No single individual has encompassed within his life-time so much of the history of Canadian entomology as has Edmund Walker. As a boy his interest in insects had been encouraged by William Saunders. As a young professor in the University of Toronto he took over the editorship of the Canadian Entomologist from Charles Bethune, and fulfilled the obligations of that position for ten years. It was his knowledge of arthropod morphology which enabled him correctly to assess the significance of Grylloblatta campodeiformis Walker, the first representative of a remarkable group of living-fossil insects which he discovered; the same Grylloblatta now resides on the official emblem of the Entomological Society of Canada (see Figs. 7 and 10). As the Society approached the one-hundredth anniversary of its founding, Edmund Walker was bringing to completion a three-volume monograph on the Odonata of Canada, the result of a life-time of study and one of the most comprehensive works ever published on a group of Canadian insects. And at a special convocation of Carleton University marking the centennial meeting of the Entomological Society of Canada, the degree, Doctor of Science honoris causa, was conferred upon Edmund Walker as one of Canada's most distinguished entomologists.

It seemed appropriate that there be a permanent record of the events relating to the centennial which took place at the Museum, and because Dr. Walker was a central figure in all of them, that this should be extended to serve as a tribute to him from the Museum, the rest of the University, and from the science of entomology in Canada, to each of which he has contributed so fully throughout his life. This tribute takes the form of an appreciation of the diverse facets of the Walker career, with sections contributed by colleagues and former students who are familiar with him and his work. To these has been added a list of Dr. Walker's scientific publications, compiled by the staff of the Museum's library. By good fortune, Dr. Walker already had in manuscript an autobiographic sketch, and this he made available for publication here. 
To know Edmund Walker is to have a heightened respect for the depth and charm of the human intellect. His native talents suited him for a career in art or music or literature; his formal training was largely in medicine; his heart was in science, and biology is the richer for it. It is the hope of those who have contributed to this volume that the unique personality, as well as the scientific achievements, of Edmund Walker may be better appreciated by those who have not had the privilege of his friendship.

The life and work of one of the pioneers of entomology in this country can be an inspiration and a source of satisfaction and pride for all students of this science in Canada. 


\section{Entomology in Canada}

ADDRESS FOR THE OPENING AT THE ROYAL ONTARIO

MUSEUM OF THE SPECIAL EXHIBIT MARKING

THE CENTENNIAL OF ENTOMOLOGY IN CANADA, 1963

\section{G. P. HOLLAND}

On April 16, 1863, exactly one hundred years ago, nine men met in the rooms of the Canadian Institute in Toronto and founded the Entomological Society of Canada (see Fig. 1). Though we cannot note the centenary of this important event by meeting tonight in the same spot (the building was demolished in 1876), we are doing just as well by assembling in the Royal Ontario Museum of the University of Toronto. The University and the associated Museum possess a long and distinguished tradition in the field of entomology, and we should be grateful to Dr. W. E. Swinton, Dr. Glenn Wiggins, and their associates for preparing the notable display that is to be unveiled tonight.

May I briefly tell you something of the history of organized entomology in this country? Though the founding meeting of the Society was attended by only nine men, there were many more than nine enthusiastic entomologists in pre-Confederation Canada. A list of thirty-six persons interested in this field was published in the Canadian Naturalist and Geologist in June, 1862, and many of these joined the Society soon after the founding meeting. All were what we would call amateur entomologists, though a number of them were to become well known in the professional entomological field. Some became notable in other fields. One was Cornelius Krieghoff, the painter, who was especially interested in moths and beetles. According to Mr. G. S. Walley of the Entomology Research Institute, one of 
Krieghoff's paintings of the Laval area, Quebec, shows dead conifers, almost certainly killed by Dendroctonus bark beetles or by the spruce budworm.

The Society owed its origin to the enthusiasm of two young men, Charles James Stewart Bethune, a student of Trinity College, Toronto, and William Saunders, a druggist and chemist of London, Canada West. Introduced to each other by Dr. Henry Croft, professor of chemistry at the University of Toronto, the two became fast friends, and met often with Professor Croft to discuss their avocation, entomology. These three men were the founding fathers of the Society. The avocation became, in great measure, the vocation of Bethune and Saunders. Dr. Bethune, after spending nine years in the Anglican priesthood, became headmaster of Trinity College School, Port Hope, a position he held for many years. In 1906 he accepted the Chair of Entomology and Zoology at the Ontario Agricultural College, finally retiring in 1920.

Dr. Saunders, technically trained in chemistry, was for many years a retail and wholesale druggist. But he maintained an active interest in entomology, botany, and horticulture. He was active in the affairs of a number of societies related to his fields of interest and became one of the original Fellows of the Royal Society of Canada. In 1883 he wrote a book, Insects Injurious to Fruits, which remained a standard work for the next quarter century. In 1886 he was appointed director of the Experimental Farms of the Dominion of Canada and moved to Ottawa to found the Experimental Farms System which he guided for twenty-five years.

On July 17,1868 , the Society resolved to publish a periodical to be distributed free to members and sold to subscribers, a plan that would appeal to many of us today. The Canadian Entomologist, published continuously for ninety-five years, is the oldest entomological journal now published on the continent, and is acknowledged as one of the best in the world.

In 1870 the Society was asked by the Ontario Department of Agriculture to prepare a report on injurious insects. This was done by Saunders, Bethune, and Edmund Baynes Reed, and became the first Annual Report ${ }^{1}$ of the Society, another periodical that has come down to us today in unbroken sequence. As a consequence of this publication, the Ontario Government supported the Society with an annual grant, and the Society was incorporated by act of legislature

${ }^{1}$ Now known as the Proceedings of the Society. 
Quar Sir.-

ot elleeting ofs Entomoloyists will be held on Sthurstay, the 16: of etprill, at Thive is Clock oy.me., in the Thooms of the Cainadian Sinstitute, Counts

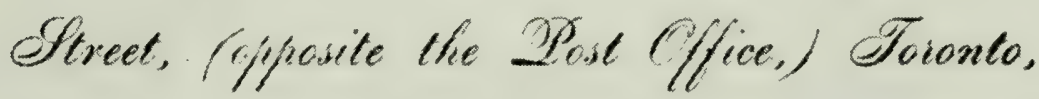
for the opuinisese of tating into consideration the

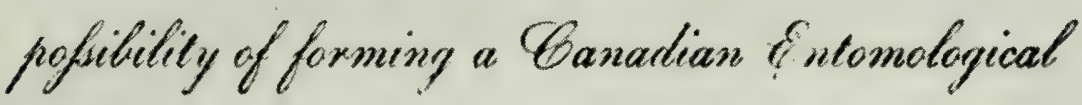
Cluk, etc., etc.

Ofou axe iesipectfully, requesited to altend, and bing with you as many syecimens as you can, locth of derificates and saities.

Ifour Obectients ESeivants.

C. J. S. BETIIUNE, Cobovry.

Wm. SATNDERS, London, $c$.

Ar. DS. Ct Cllecting will puchally be held in the evening of the same day abo.

FIGURE 1. Invitation to the founding meeting of the Entomological Society of Canada, April 16, 1863. 


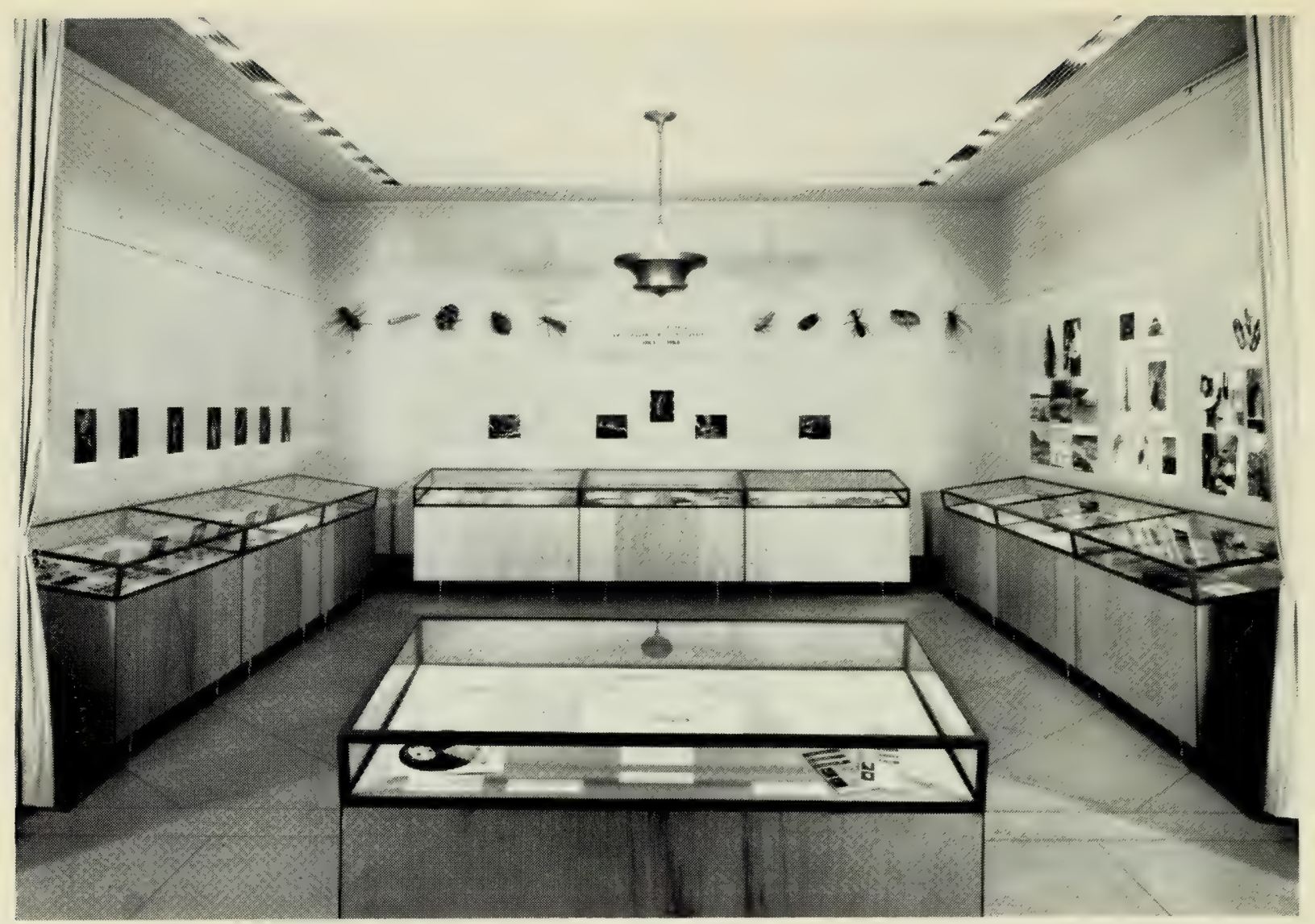

FIGURE 2. Special Exhibit in the Life Sciences Galleries of the Royal Ontario Museum to mark the centennial of the Society.

Centre foreground: The Science of Entomology.

Centre background, left to right: The Entomological Society of Canada, 1863-1963;

C. J. S. Bethune and William Saunders; The Canadian Entomologist.

Left side, foreground to background: Canadian Insects; Edmund M. Walker;

Entomology in the Royal Ontario Museum.

Right side, foreground to background, with accompanying photographs on wall:

Modern Methods of Insect Control; Biological Control in Forest Entomology;

Entomology in the North.

Rear wall: Enlarged models of common insects and one crustacean.

Acknowledgment is made to the Canada Department of Agriculture and the

Canada Department of Forestry and to the Entomological Society of Ontario for the provision of certain of the materials used in the exhibit.

Exhibit prepared by T. M. Shortt, A. Gatti, and Miss C. N. Storwick with the technical supervision of G. B. Wiggins. 
in 1871 , a step that necessitated the changing of its name to the Entomological Society of Ontario.

In 1872 the Society moved its headquarters to London where it remained for thirty-four years, moving once again, in 1906, to Guelph, where headquarters were established at the Ontario Agricultural College.

Though provincial in name, the Society was always national in outlook and objectives. As regional entomological societies sprang up in British Columbia and other provinces, they established a form of affiliation, and some of the directors of the parent society were selected from these provinces.

In 1950, a further step was taken. A newly constituted Entomological Society of Canada was established, with headquarters at Ottawa, and with seven regional, affiliated societies. Spawned by the Entomological Society of Ontario, the child was larger than the parent, and took over some of the parent's responsibilities. The national objectives and the publication of the Canadian Entomologist became the responsibility of the new national society, while the Entomological Society of Ontario withdrew to a provincial role, continuing to publish the Annual Report, a periodical that, over the years, has increased tremendously in scope and significance.

Thus, today, we have two societies, each possessing a thread that can be traced back for one hundred years. To mark the centennial, therefore, the two Societies have decided to meet jointly, at Carleton University, Ottawa. This event will take place September 3-6 of this year. ${ }^{2}$ His Excellency, Major-General Georges P. Vanier, GovernorGeneral of Canada, has been pleased to lend his distinguished patronage to the centennial. A special convocation of Carleton University will be a feature of the event.

Let us now take a brief look at the growth of entomology in Canada over the past century. In 1863 there were 36 amateur entomologists; in 1963 there are nearly 500 professionals, about 210 of them employed by the Department of Agriculture and 120 by the Department of Forestry. About 60 are associated with Canadian universities and 30 with provincial governments and museums. About 20 are commercially employed as entomologists and about 50 are employed by various other agencies.

2[1964. Centennial of Entomology in Canada, 1863-1963: Proceedings of a commemorative joint meeting of the Entomological Society of Canada and the Entomological Society of Ontario. Canad. Ent. 96(1-2): 475 pp.] 
Though entomology is a splendid avocation and was organized in Canada as the result of the interest of hobbyists, the economic necessity imposed by the insects themselves became the underlying and recurring stimulus that contributed to its development as a science or, rather, as a series of sciences. Entomology, like medicine and other fields, has become a realm of specialties, and the specialists do not always speak the same language. Thus there are taxonomists, behaviourists, ecologists, geneticists, cytologists, morphologists, embryologists, histologists, histochemists, nutritionists, and toxicologists. There are population dynamicists, specialists in pesticide-dispensing equipment, in bioclimatology, in radio-active tagging, in chemosterilants, in insect pathology, in the effects of supercooling, and the responses of insects to sounds, sounds that may attract, repel, or even kill insects. A physiologist working with only one species may not know the differences between a fly and a flea; a taxonomist might not consider such a person as even being an entomologist!

Problems of pest control have become much more difficult than they were in the early days. With the increase of acreages devoted to single crops, insect problems increased. A Destructive Insect and Pest Act, passed in 1910, was necessary to guard against the introduction and spread of pests. The early chemical palliatives such as Paris Green and sodium silico-fluoride, and the colourful preparation known as Criddle Mixture, no longer solved the problems. The synthetics, the organophosphates, chlorinated hydrocarbons, and others, developed extensively since World War II, brought problems of toxic residues and the development of resistant strains of pests. Entomology entered the atomic age, and sterilization and extinction of populations of certain pests was achieved by the use of radio-active materials. The control of insects by genetic means is a new field based on the principle of hybridizing races that yield intersexes or sterile individuals that are unable to propagate. Modified spray programmes and integrated methods of insect control utilizing chemical, biological, and cultural techniques, have been developed to cope with some of the more difficult problems. The data associated with certain broad ecological investigations have become so complex they can only be digested by electronic computers. Biological control methods include a range of activities quite unheard of in the early days. Insect taxonomy is based on sounder concepts of species than formerly, and the evidence is that the Canadian fauna may include more than 60,000 species. Refined methods and techniques including cytology and comparative 
serology have revealed the important fact that many species are not, or are barely, distinguishable on morphological criteria. It has been necessary to sample the insect fauna on a grand scale and to develop insect collections of which the Canadian National Collection, formally established in 1917 under the administration of the Department of Agriculture, is by far the largest and most representative.

Yes, the picture has changed greatly since those early days of enthusiastic amateurs and empirical methods. In 1883, eighty years ago, Dr. James Fletcher was appointed as honorary entomologist to the Dominion Department of Agriculture. Later to be called Dominion Entomologist and Botanist, Fletcher was one of the founding fathers, with L. O. Howard of Washington, of the American Association of Economic Entomologists, the first meeting of which was held in 1889 in Toronto, in association with the meetings of the A.A.A.S.

By the early 1900 's, entomology became recognized as a profession in its own right in the government service and was separated from botany into a distinct division of the Experimental Farms Service. In 1909, Fletcher was succeeded by Dr. Charles Gordon Hewitt. Hewitt quickly established small field laboratories in most of the provinces and in 1912 initiated special investigations of forest insect problems under J. M. Swaine. Forest entomology remained with agricultural entomology until 1960 when it was amalgamated with the Forestry Branch of the Department of Northern Affairs and National Resources in a new Department of Forestry.

The organization of entomology in the Department of Agriculture changed over the years; in 1937, Science Service was budded off from the Experimental Farms as the main scientific arm of the Department with entomology as one of the fields covered. In the departmental reorganization of 1959, the reverse step was taken, and Science Service and the Experimental Farms Service were reunited as the Research Branch, and entomology became concentrated in three research institutes specifically devoted to this field and was also well represented in a goodly number of research stations and regional laboratories where the entomologists, in concert with specialists in other fields, were encouraged to adopt the team approach to agricultural problems.

The Division of Foreign Pests Suppression of the Entomological Branch, established in 1919, later became the Plant Protection Division of the Department.

The teaching of entomology in Canadian universities proceeded 
slowly at first. Special options at a number of institutions were established by 1920 and there has been great, though still insufficient, growth of staff and facilities at many universities and colleges since World War II. Many of our most eminent Canadian entomologists are associated with the universities and it is gratifying to see an everincreasing proportion of Canadian graduate students proceeding to their higher degrees in this country rather than elsewhere. A number of exciting and basic lines of research are being undertaken at the universities and it is to be hoped that the trend, now well established, will grow and flourish.

In this short account I shall not attempt to review specific entomological problems, past or present, or to estimate the tremendous savings to the national economy brought about by the efforts of entomologists. As a single example, from the field of agricultural entomology and plant breeding, it has been estimated that the development of wheats resistant to the wheat-stem sawfly has prevented losses of 5 to 10 million bushels annually since 1950 . Dr. C. W. Farstad, President of the Entomological Society of Canada, and with us here today, was, with A. W. Platt of the Experimental Farms Service, responsible for this triumph.

It is fair to say, now, that Canada has achieved a notable reputation in many fields of entomology, in the universities and in the government agencies. I shall not attempt to cover them but I hope that all entomologists and other interested biologists here this afternoon will plan to be in Ottawa this September, when a goodly sample of the best that Canadian entomology has to offer today will be featured, either by formal papers or by special exhibits based on research projects. Much of Canadian entomology was reviewed in 1956 when the Tenth International Congress of Entomology was held in Montreal. This was the largest assemblage of entomologists ever gathered, and one of the most successful meetings of all time. The centennial meetings are not planned on quite so lavish a scale, though we hope that the programme, which is entirely by invitation, will be of interest and that it will be considered more noteworthy and newsworthy than the theft of certain butterflies. ...

Canada now plays a proportional, and perhaps more than a proportional, role in international entomology. Canadians have taken part in WHO and FAO assignments in many parts of the world; by on-the-spot participation, they have assisted underdeveloped nations in the solution of problems affecting their agriculture, or the health 
of their people. They have participated extensively in the planning of international agreements on procedures concerning residues of, and resistance to, pesticides. Canada's entomological contributions in the future can be expected to further increase the production and quality of food and fibre, and to continue to aid in the reduction of disease and annoyance caused by insects and allied organisms. These are practical objectives associated with Canada's present and increasing status in fundamental research in many aspects of entomology.

In drawing my remarks to a close, I wish to mention the importance of museums in the field of entomology as well as other lines of natural history. A fact often not appreciated by the public is that museums are much more than showcases, and that important and original research goes on behind all those mysterious closed doors connecting with the public galleries. The Royal Ontario Museum is a splendid example of the best in museums in the traditional sense and it enjoys an outstanding reputation in many fields of research, amongst them, entomology. Major contributions to the science of entomology have emanated from this institution and the associated University of Toronto. I wish, today, to pay special tribute to the career of one man, whom we are honoured to have with us today, Professor Emeritus Edmund M. Walker. Dr. Walker will aways be remembered for his discovery of, and his studies on, the famous "ice bug," Grylloblatta campodeiformis, and for his magnificent studies on Canadian dragonflies, culminating in a monograph of three volumes of which two are already in print. I am happy to be able to announce to you, today, that Professor Walker's contributions to the science of entomology will be marked, during the formal meetings of the centennial of entomology at Ottawa this September, by the conferring on him of the honorary degree of Doctor of Science by Carleton University [see Fig. 4].

And now, ladies and gentlemen, I will draw the curtain and declare this exhibit, marking one hundred years of entomology in Canada, open. 


\title{
Autobiographic Sketch
}

\author{
EDMUND M. WALKER
}

BOYHOOD AND STUDENT DAYS

In my undergraduate days, seventy years ago, the only training in entomology available in Canada was that offered by the agricultural colleges. The leading entomologists of that period were either selftaught amateurs or persons who became interested in insects as a sideline necessary to their main pursuit. Dr. William Saunders, first director of the Experimental Farms at Ottawa and author of Insects Injurious to Fruits, began his career as a pioneer druggist in London, Ontario. He early developed a special interest in botanical drugs, particularly those of the New World, and he was also an ardent horticulturist. These interests naturally led him to study entomology through the need for attacking the problems of controlling insect pests. He was one of the founders of the Entomological Society of Canada, which later became the Entomological Society of Ontario owing to the financial support which it received from the Ontario Government. ${ }^{1}$

The Reverend Charles J. S. Bethune was a co-founder of the same Society and the first editor of its journal, the Canadian Entomologist. Indeed, for fifteen months the two founders supplied all the articles which appeared in that journal. Dr. Bethune had been headmaster of Trinity College, a boys' school in Port Hope, Ontario, but later became professor of entomology at the Ontario Agricultural College. He was another example of an amateur entomologist who, without entomological training, became a professional. ${ }^{2}$

\footnotetext{
1 [The Saunders story is recounted in a book by Elsie M. Pomeroy (1956): William Saunders and his five sons. Ryerson Press, Toronto. Tribute to his contribution to entomology in Canada is paid in an obituary written by C. J. S. Bethune (1914): Canad. Ent. 46 (10): 333-336.]

2[A summary of Dr. Bethune's role in the development of Canadian entomology
} 
One other amateur who attained the highest entomological position in Canada was Dr. James Fletcher. He was appointed to the double office of Dominion Entomologist and Botanist. Before this appointment he was assistant in the Library of Parliament at Ottawa. Although he lacked scientific training he was a man of vast enthusiasm and energy, with great personal magnetism. He made a host of friends and was in constant demand as a speaker. He also became a recognized local authority in both of his fields-entomology and botany. ${ }^{3}$

These three men-Saunders, Bethune and Fletcher-were among the most prominent of the pioneer generation of entomologists in Ontario. Their immediate followers had, for the most part, the greater advantage of some training in the basic sciences, though not necessarily in entomology. I was one of this second generation and, as I also had no advantage of a course in entomology, it may be of some interest to enquire how I ever came to be an entomologist at all. To answer this question, I must deal briefly with the two factors of heredity and environment, to which I feel I owe a great deal.

My earliest memories of the outside world are of horses, and this is natural since I was born in the horse-and-buggy era. But I had an inborn love of animals, both as fellow creatures and as objects of interest and attraction. My greatest pleasure was drawing, which I began to practise before I was three years old.

When I was seven or eight I began to classify animals. Donkeys were familiar animals in the eighties and when my father spoke of the donkey as a "cousin of the horse" he seemed to me to express something I could see myself, although I made no attempt to analyze it. When at a zoo I saw a lion and a tiger for the first time I was greatly interested to observe that they were unmistakably cats. All their actions were precisely like those of Kelpie, our family cat. "What about mosquitoes?" I asked Father." "Would they be on the same chain?" I shall never forget his answer, "Oh yes, they must have been somewhere along the same chain."

Our family came from Hamilton, Ontario, where my paternal grandfather lived long after we had moved elsewhere. ${ }^{5}$ Grandfather

appeared in 1932: Canad. Ent. 64(5): 97-98. His own extensive collection of insects was turned over to the Royal Ontario Museum where it is now incorporated into the research collection.]

3 [Dr. Fletcher's contributions to entomology and botany in Canada were outlined in an obituary written by C. J. S. Bethune (1908): Canad. Ent. 40 (12): 433-437. A second tribute to his work appeared in 1908: Ottawa Naturalist, 22: 206-233.]

4 [Sir Edmund Walker (see pp. 48-49).]

5 [Dr. Walker himself was born at Windsor, Ont., on October 5, 1877.] 
had a scientific bent and collected fossils on the Hamilton "mountain," the bold escarpment over which the Niagara River falls. My father followed the same hobby and in the course of time built up a very fine collection and paleontological library, which eventually became the nucleus of the collection of the University of Toronto and later went to the Royal Ontario Museum.

Both Grandfather and Father were interested in natural history in a broad sense, and Father told me years later with what satisfaction they read Darwin's Origin of Species when it first appeared. They devoured it eagerly and accepted it with enthusiasm, for it gave them a logical explanation of much that was hinted at in their studies of fossils. By the time I was old enough to understand what was meant by evolution I was ready to accept it, although my ideas of the process were still vague and very limited.

But I owe my father and grandfather a great deal, both for the genes through which I inherited my flair for natural history, and for the environment, which they created, of books and pictures and of ready access to fields, woods, and streams in which I grew up.

The year 1890 was a memorable year for our entire family. My father had a cottage built at DeGrassi Point on Lake Simcoe, Ontario, a property that had just been opened up as a summer resort. The cottage was to be ready for occupation on the first of August, but I was invited to spend July at the same locality with my uncle's family. $\mathrm{He}$ was a professor of English and I was a twelve-year-old boy with no companion of my age. I was thrown upon my own resources. It was the beginning of July and the first morning I came out on the verandah I found hundreds of big mayflies (Hexagenia) sluggishly resting on the wall and the floor, some of them shedding their skins and others with their shed skins beside them. I knew little of insects and had never seen one shed its skin, certainly not after having acquired wings and the ability to fly. This observation greatly aroused my curiosity in insects. I wandered everywhere watching insects and before long I made up my mind I would start a collection. A school chum with similar interests joined me when our cottage was finished, and so began our first season of collecting and observing insects. We went out almost every day and always found something new and exciting. Our only book of reference was the Standard Natural History, volume II, but by the end of the season, after we had collected another month at Toronto, we knew all the larger orders and 
a great many families, and were familiar with a considerable number of genera and species, quite a number of which we had identified as well as could be expected under the circumstances that limited our efforts. I had never enjoyed myself so much in my life.

But if collecting in August and September, 1890, was a thrilling experience, the entire season of 1891 was vastly more exciting and engrossing. My father had given me Maynard's Butterflies of New England and Harris' Insects Injurious to Vegetation, and Dr. William Saunders, already mentioned as one of the pioneers in entomology in Canada and a close friend of my father's, presented me with a copy of his well-known treatise Insects Injurious to Fruits. All of these books I prized greatly but, except for butterflies and the more conspicuous moths and beetles, it was very difficult at this period to identify insects of any order, even approximately, except by sending them to a specialist, and even the specialists in those days were pioneers in their fields.

During this summer and for several summers thereafter, my chum Graeme Stewart and I collected almost daily at DeGrassi Point and we acquired a considerable fund of general information about insects. It was the time of life when memory is quick and tenacious and both of us had good memories for names. We attached little value to this faculty for it came without effort, but many years later these names were still retained and provided many pegs on which to hang other facts as they were gathered.

During high school years in Toronto we made friends with several other ardent collectors of insects and met a few men of mature age who were interested in entomology or general natural history. I shall mention only one of these-Dr. William Brodie-for it was he who gave us the greatest help and encouragement. Dr. Brodie was a dentist by profession but a naturalist and philosopher by temperament. He was an elderly Scotsman, kindly and helpful to young men and boys in whom he perceived a genuine interest in nature and a desire to learn the truth, but intolerant of those in whom he detected any trace of insincerity. He was one of the old-time naturalists whose field was all of nature, but he was essentially a biologist as well as a naturalist. His chief specialty was the study of galls and gall insects, particularly the Cynipoidea. It was to Dr. Brodie that Stewart and I made pilgrimages from time to time, taking to him specimens of various groups for identification. Dr. Brodie's influence was wide 
locally. It is unfortunate that he published very little, although after retirement from his profession he spent a few happy years as the first Provincial Biologist of Ontario. ${ }^{6}$

Toronto was a relatively small city in the "nineties," having a population of only about 100,000. We lived on St. George Street, scarcely more than a block from Bloor Street, which was the city limit. Beyond Bloor, St. George Street was an unpaved road leading through open fields to Davenport Road, at the base of the wooded slope which is the old beach of post-glacial Lake Iroquois. Along Davenport and Poplar Plains Road were wooded estates pleasantly diversified by a ravine with its little running brook. This was so easily accessible that it became my usual collecting resort for short excursions.

The most popular type of collecting in those days, however, was done at night around the arc lamps, which illuminated the street corners efficiently but left the intervening spaces in comparative darkness. This kind of collecting was a thrilling experience. There were so many large insects we had never seen before, although most of them were easy to identify from 'our books: the great silkworm moths, the many large hawk-moths, the big diving-beetles and, most astonishing of all to me, the giant water bugs, which I had read about but never imagined would be found in Canada. I was not surprised later to hear that they were called electric light bugs.

The best locality in the Toronto area for general collecting was undoubtedly High Park. With its open sandy slopes facing southward over Lake Ontario, a variety of southern plants and insects reached their northern limits here. The black oak, the sassafras, and the wild lupine, which once covered several acres, were among the most notable plants and each of these had some characteristic insect associate, such as the green swallowtail with the sassafras and Scudder's blue with the lupine.

After a few years of general collecting in which I obtained considerable familiarity with most of the orders, I began to give more and more attention to the Orthoptera. I started to correspond with W. S.

\footnotetext{
6[In addition to his own personal work with insects, extending through much of his life, Dr. Brodie took charge of the Biological Department of the Provincial Museum in 1903. His own large collection of insects was one of the original components in the formation of the insect collection of the Royal Ontario Museum. He was also active in the Toronto Branch of the Entomological Society of Ontario, as was Dr. Walker, too. Dr. Brodie's obituary, accompanied by a photograph of him working with his collection of insects, was published in the 40th Ann. Rept. Ent. Soc. Ont., for 1909, (1910) pp. 129-131. A further reference to his contribution to entomology was published in 1910. Canad. Ent. 42: 47-48.]
} 
Blatchley and S. H. Scudder, then A. P. Morse, A. N. Caudell, L. Bruner and others.

Stewart and I entered the University of Toronto in the fall of 1896 , both of us choosing the Natural Science course, which was the broadest of the various science courses in the Faculty of Arts offered at that period and the only one that emphasized biology.

R. Ramsay Wright, professor of biology, had been very energetic in developing laboratory courses and equipment that were thoroughly modern for his period. He gave a course of lectures that is still recalled by the few students of his who now remain. As a first-year student I found these lectures lucid and stimulating, for they were essentially a survey of the animal kingdom with special emphasis on the evolution of the phyla and classes, although the word evolution was avoided in public in the nineties and even later.

As taught at this period, however, biology was a one-sided subject. Morphology dominated nearly every course and the study of living animals and plants was almost ignored. This is scarcely surprising, for the new methods of microscopical technique revealed such a vast unknown field for the investigation of the structure and development of animals and plants that every student was keen to add some details to the accumulating mass of knowledge.

Physiology was not wholly neglected, but it was mainly mammalian physiology and very elementary. Biochemistry was in its infancy and was taught as a branch of physiology. Only a few years after our class of 1900 graduated, physiology and biochemistry became a separate department from biology and developed so rapidly that within a year or two it subdivided again.

The summer of 1897 , after my first year as a university student, was another memorable one for me. The British Association for the Advancement of Science met in Toronto and both Dr. William Saunders and my father served as local secretaries. When the meetings at Toronto were over, a trip to the Pacific Coast in special trains had been arranged, and I had the good fortune to be included among the passengers. In the first party were some very distinguished guests such as Lord Kelvin, the world-famous physicist, and Lady Kelvin, E. B. Poulton of Oxford, one of the greatest entomologists of his time, Marshall Ward and F. O. Bower, distinguished botanist, W. A. Herdman, a leading oceanographer, and several other outstanding scientists.

The botanists and entomologists, at every opportunity, collected 
plants and insects close to the railway stations. I had become familiar with most of the eastern Canadian Orthoptera and some of the western species, so that Professor Poulton, who was collecting for Oxford University, sought my assistance while papering his specimens. I could give him the generic name of most of his captures and, as they were chiefly short-horned grasshoppers, I was dubbed the Acridiologist of the party. I felt honoured indeed to be able in any way to assist so eminent a man as Professor Poulton.

When we reached Banff, Alberta, in the heart of the Rocky Mountains, we came to a stop to await the arrival of the geological party on the following train. For me this part of our trip brought the most important event in the entire journey. I met the pioneer botanist, John Macoun, naturalist to the Geological Survey of Canada, and he at once invited me to climb with him to the top of Sulphur Mountain, a small mountain close to the town. I had never climbed a mountain and this one would not be worth mentioning here, were it not for the great interest of passing through the various belts of vegetation from the Bow Valley with its tall white spruce, lodge-pole pine, and scattered Douglas firs, to the white-barked pines and Lyall's larch at the timber-line. Professor Macoun noted many interesting plants characteristic of the various zones, as we climbed upward. I had already been interested in plants, especially trees, for a few years, and to become acquainted with the western conifers of the various zones in Banff and beyond the "Great Divide" was an unforgettable experience.

We made several short stops from half an hour to a day or more on the way to the Pacific Coast, and whenever we stopped I looked for grasshoppers and usually added one or two species that were new to me. My most thrilling experience was at the ranch of Lord Aberdeen, then Governor-General of Canada. This was situated at Vernon, in the Okanagan Valley, where the party stopped for several hours. I slipped away to the dry rolling hills nearby and was fairly bewildered with the variety of Acrididae. I had become specially interested in those oedipodine grasshoppers, such as Circotettix undulatus, that fly about high above the ground and make a loud snapping noise. Among the bare hills of the Okanagan Valley these sounds were intensified and the dramatic effect was thereby considerably increased.

The party broke up after we had reached Vancouver and Victoria, and my memories of the return trip center about a five-hundred-mile drive through the wheat-growing districts of Manitoba, which my 
father wished to see at first hand. He was then General Manager of the Canadian Bank of Commerce and this was a time when new branches of the bank were springing up in all the newly settled districts. Entomologically this wheat-growing country was less interesting than the semi-arid region we had passed through on our way to the Pacific coast.

Soon after we returned to Toronto, I was at the University, but found time to publish a few papers. These were faunistic papers on Orthoptera, chiefly on our local species, and beginning with the Acrididae. They included my first new species, one from Ontario and the other from the Rocky Mountains of Alberta and British Columbia.

I entered Medicine at my father's suggestion which appeared to be a sound one, since positions in the biological field at the turn of the century were few in Canada and I had no wish to leave this country if I could possibly avoid it. Father argued that I might become as much interested in the characteristics and classification of diseases as in those of animals and plants. I felt rather dubious about this, but could think of no better alternative.

Graduating in Arts (Natural Science) in 1900 and having also finished the first year in Medicine, I had three more years of study to complete the medical course. In 1903, I graduated from Medicine, taking also a Medical Council examination, which qualified me to practise. I received an appointment as intern in the Toronto General Hospital and accordingly spent the year there. By the end of that year, however, my interest in medicine was still only lukewarm. Fortunately, my wise uncle, Professor Alexander, could see the error of my ways and gave me the necessary impetus and encouragement to return to the field of biology before it was too late.

After a year in the Department of Biology with Professor Wright, I went to Germany for a year of postgraduate work and enrolled in the University of Berlin. Knowing that invertebrate zoology was not adequately represented at the University of Toronto, I took a laboratory course in this subject conducted by Dr. Paul Deegener, at that time a Privatdocent, but destined to become an outstanding authority on insect anatomy. This laboratory course was carried on daily from Monday to Friday. Dr. Deegener was always on hand for consultation and when the class was ready to begin a new group, he would give a short introductory talk, and a very good talk it was.

Occasional field trips were made which students from various courses would attend. On one of these I met J. H. McDunnough of 
Toronto, who was working toward his PH.D. degree. This unexpected meeting with a fellow Canadian entomologist in Germany was for me a very happy occasion.

Besides Dr. Deegener's laboratory course I followed a course of lectures on general zoology by Professor F. E. Schulze, who was professor ordinarius in zoology at the University of Berlin and the leading authority on sponges. Both Professor Schulze's lectures and Dr. Deegener's laboratory talks were presented with clarity and vigour and were of great value to me in familiarizing me with the German language.

\section{TEACHER AND COLLECTOR}

Early in the summer of 1906 I was notified that I had been appointed lecturer in invertebrate zoology at the University of Toronto. I was to give a course of 25 lectures and 50 hours laboratory work to students in the second year of the honour course in Biology.

The summer of 1907 was spent as curator of the Great Lakes Biological Station at Go Home Bay, Georgian Bay, Ontario, and of this I shall give some account later. In the autumn I was asked by Professor Wright to prepare another course in invertebrate zoology which would emphasize the parasitic forms. This was to be given as part of a premedical course known as the Biological and Physical Sciences, which had been established the year before. I found our Department sadly lacking in material for such a course. I had to use a variety of parasitic animals that were of little if any interest from a medical standpoint, but at least we had some representation of most of the major groups, even though they were not the type we most desired.

Biological and Physical Sciences was a short-lived course, being finally replaced by one known as Physiology and Biochemistry. My course, Parasitology, eventually became one of several optional courses in medicine, but after a few years these optional courses were eliminated and parasitology was transferred to the School of Hygiene and was no longer in my hands.

In 1907 the Faculty of Forestry was established at the University of Toronto with Dr. B. E. Fernow as Dean. Among the subjects required was forest entomology, and being the only staff member who had any knowledge of insects, I was asked if I would prepare a 
course on this subject. Since only 75 hours could be spared for entomology, I attempted an introduction to general entomology leading up to a few lectures and laboratory periods on forest entomology. Throughout the course I used forest insects as types in so far as this was possible. If the student could acquire some appreciation of the role played by insects in the destruction of the forests and some idea of the methods of control, both natural and artificial, the course would be better than nothing. Although very poorly equipped to begin with, we became better prepared as each year passed, and many years before my retirement a fully trained and experienced forest entomologist (Dr. C. E. Atwood) was added to our staff. He gave his entire time to the subject, both in teaching and research.

In 1910, Dr. Bethune resigned from the editorship of the Canadian Entomologist after holding this post for fourteen years. He asked me to relieve him of this task and I agreed to do so, although I had little idea of the time that such editorial work required. As it turned out, there was considerable correspondence, but not much other routine work except the editing of papers and correcting of proofs twice a month. After ten years, however, I felt it was time for someone else to take over this task. Thus I was succeeded in 1921 by Dr. J. H. McDunnough.

In 1912, Professor Wright retired from the University and was succeeded by Dr. B. A. Bensley as head of the Department of Biology. Meanwhile a new and important event affecting several departments of the University, the opening of the Royal Ontario Museum, was soon to take place. The first wing was in the course of construction and was expected to be opened in 1914. The University Department of Biology had not yet separated into Botany and Zoology, but the botanists were not interested in the new Museum, so that the single gallery and part of the basement that were allotted to "Natural History" were available to Zoology alone, separate provisions having been made for the Departments of Geology, Palaeontology, and Mineralogy.

The story of the origin of the Royal Ontario Museum is an interesting one, but is too long to be told here. Previously, the Department of Biology had been provided by Ramsay Wright and some of his predecessors with an excellent teaching museum of zoology but much of the material in this museum was never used in classes. It was, therefore, transferred to the Royal Ontario Museum to assist in filling the new gallery. 
Although I had at first no official connection with the new Museum, I felt that it was my responsibility to build up the collection of invertebrates, and I was also interested in developing a collection of casts of our native fishes. Because of a criticism I had heard of the miserable little handful of fishes we had to start with, I was determined that ours should become one of the finest collections of fish casts in Canada. I arranged with Mr. Kurata ${ }^{7}$ that we would work together and make a number of trips combining the collecting of fishes and Odonata, an order of insects which had been neglected in Canada and in which I was especially interested.

Mr. Kurata's job was to make the moulds and later the casts of the fishes and mine was to make the watercolour drawings from which the casts were painted. This plan worked out very well especially when we obtained the co-operation of Mr. E. B. S. Logier, an extremely skillful painter of fishes, amphibians, and reptiles, and who possesses infinite patience and accuracy in depicting complex colour patterns. Mr. Logier relieved me of all such work except when I was in the field with Mr. Kurata.

Our first trip was made in the summer of 1913, the main objective being a visit of several weeks to the Pacific Biological Station on Vancouver Island, British Columbia. But we also made a few stops en route to collect insects, particularly Odonata and Orthoptera. It was at Banff in company with Mr. Kurata that I made the most remarkable discovery of my life, that of Grylloblatta, of which I shall have more to say in the third section of this paper.

At the Pacific Biological Station, we were the guests of Dr. and Mrs. C. McLean Fraser. Dr. Fraser was director of the Station and a specialist in hydroids. Later, he became head of the Department of Zoology, University of British Columbia. At this station we spent about a month collecting every day, mainly marine invertebrates from the tide pools and rocks at low tide, and we also did some dredging. Dr. Fraser was most generous of his time and energy and took us out on many dredging trips on which we obtained numerous animal forms which we would otherwise never have seen. The richness of the fauna in echinoderms and decapod Crustacea was particularly amazing to me. Of course, I took time to obtain as complete a collection as possible of the local Odonata.

$7[$ T. B. Kurata, one of the first permanent members of the staff of the Museum of Zoology] 


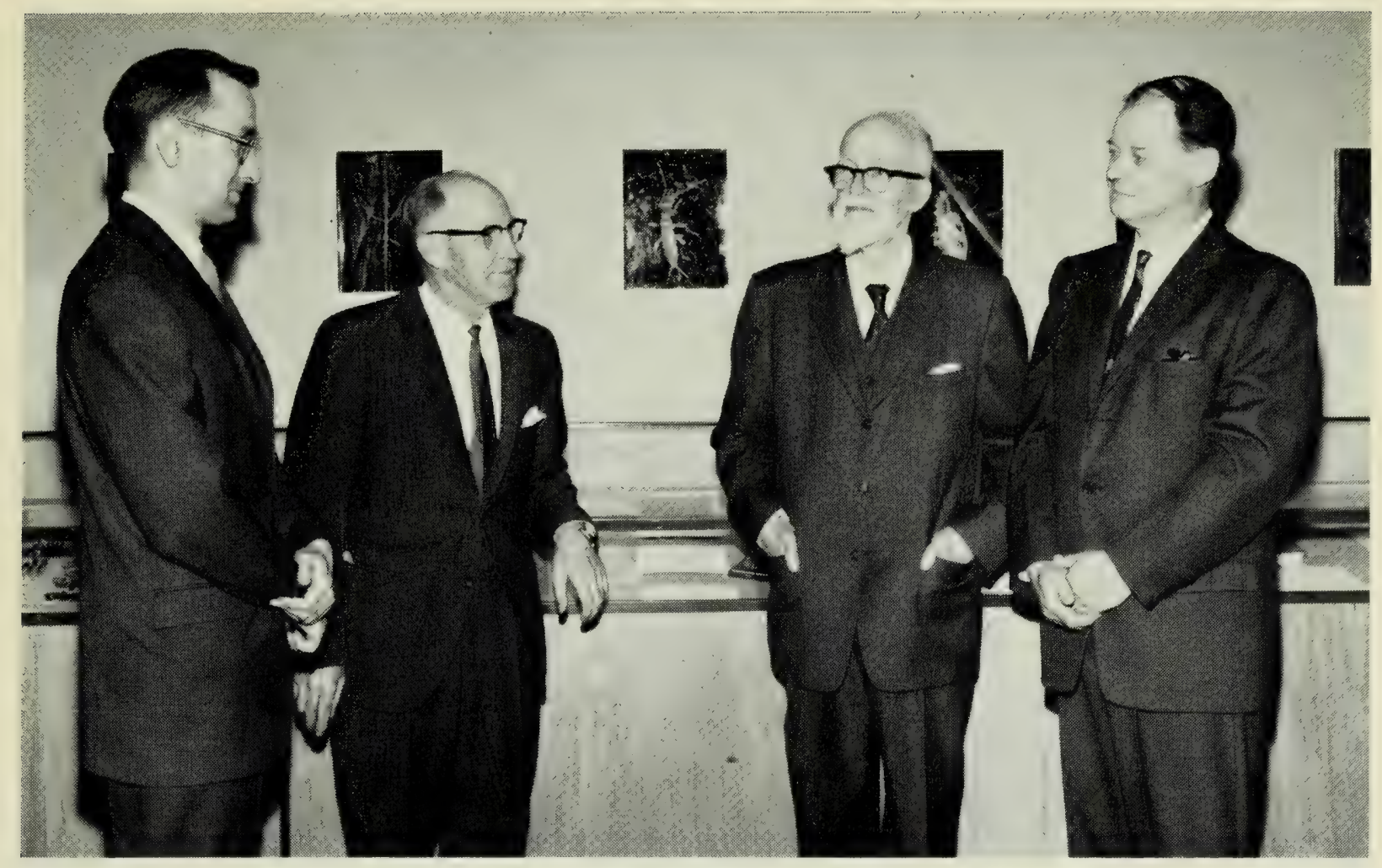

FIGURE 3. Following the opening of the special exhibit at the Royal Ontario Museum: (left to right) Dr. G. B. Wiggins, Curator of Entomology, Royal Ontario Museum; Dr. C. W. Farstad, president of the Entomological Society of Canada in 1963; Dr. E. M. Walker; Dr. G. P. Holland, chairman of the Centennial Executive Committee. 


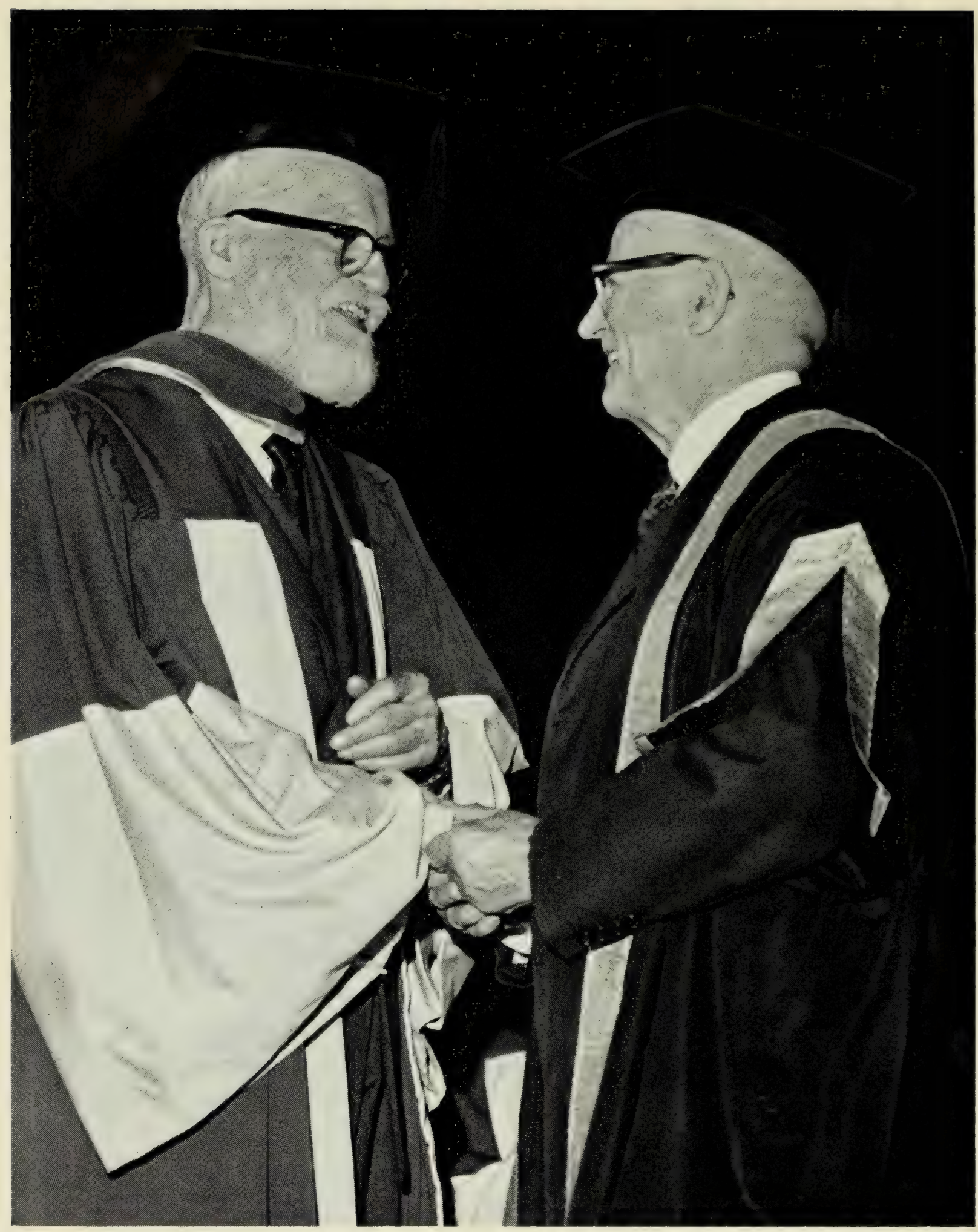

FIGURE 4. Dr. Walker receiving the congratulations of the chancellor of Carleton University, Dr. C. J. Mackenzie, upon receiving the degree Doctor of Science honoris causa, September 3, 1963. 
In 1914, during a short trip to Newfoundland, I received the first news of World War I.

The four war years were terrible years. Every day brought news of more and more casualties among our students who had enlisted, while fresh enlistments and depletion of our classes constantly occurred. Bitter feelings ran very high, so that the few students who remained behind were greatly scorned. Those of us who taught through two world wars are keenly aware of the differences in attitudes. In World War I most of the staff members who remained joined the Officers' Training Corps and every afternoon at five o'clock turned out on the campus for drill or other military exercises. The course given to the university staff, however, was much too short and not a single man passed the final tests except those who had already been chosen to serve as sergeants before the course commenced.

This was too anxious a period for research, but I wrote a few papers on material which had already been partly or completely worked over, the most important being one on the Odonata of Go Home Bay (1915g), where I had been Curator of the Great Lakes Biological Station in 1907, 1908, and 1912.

Following the war the number of students increased greatly. The curriculum in the Faculty of Arts offered two types of courses, both requiring the entrance standard of senior matriculation. These were the pass course of three years and the honour couses of four years each. The pass course was less specialized than the honour courses so that pass students could take a greater variety of subjects, although the content of each subject was less than in the honour courses.

The zoology of the pass course ran through all three years; an introductory course the first year, vertebrates the second year, and invertebrates the third year. I was assigned to the invertebrate part of the course. I gave as much attention to this course as any other and spent more time with the students because I felt that they were less capable of working independently. I tried to teach them to observe by quizzing the class at the beginning of the laboratory period when the material was placed before them. I think this method gave better results than merely telling the class what to look for. I continued to give this course with occasional variations in the content up to the end of my teaching career. I was always aided by two or three demonstrators.

One of the new courses with which I was concerned was Systematic 
Zoology. This was a course that had two principal objects: (1) to give practice in the identification of animals from a variety of different groups and, (2) to familiarize the student with a fair number of our native animals, including a relatively large number of vertebrates and a selection of invertebrates from certain groups. Professor J. R. Dymond had charge of the vertebrate part of the course while I had the invertebrates. In order that the students might acquire some familiarity with the concepts of family, genus, and species, as well as the higher categories of class and order, it was necessary to select only a few, relatively small groups for study. Thus I usually chose the land and freshwater Mollusca, the Malacostracan Crustacea, and a few of the leeches (Hirudinea) and fluke worms (Trematoda). Insects I had to omit as they were too numerous.

The course I had offered in pre-war years under the title of Advanced Invertebrate Zoology had to be limited to a very few phyla in order to be practicable in the available time. Eventually, it was reduced to the Arthropoda alone for I regarded the study of this phylum as an important basis for those students who intended to pursue graduate work in entomology. I had long been interested in the evolution and affinities of the classes of Arthropoda and, with the brilliant papers of R. E. Snodgrass as the most stimulating works of reference for the students, I felt that this was the most complete and advanced course that I had developed. I gave it during the last few years of my teaching period and for a year after I retired, a special lectureship having been provided.

Entomology was also offered as one of the options in the fourth year and was occasionally chosen, but the hours were so limited that the course could not be regarded as more than an introduction to the subject. It was chiefly morphological and taxonomic, but attention was given to the types of immature insects as well as the adults. For graduate students, the course in entomology was varied as time permitted.

In 1918, I became definitely a member of the Museum staff, having been appointed assistant director of the Royal Ontario Museum of Zoology. During the next decade I made many summer collecting trips, usually with Mr. Kurata. These were made partly in the interest of the Museum and partly for my own research on the Odonata. In particular, I wanted material in the northern genus Somatochlora for a monograph which I was writing, similar to the one I had done on the genus Aeshna in 1912. 
Many of these trips were short, occupying only a few days, whereas others extended over several weeks, sometimes a month or more. I shall refer to only two of these expeditions, those of 1918 and 1921.

In 1918, Godbout was an isolated village of fishermen and their families. We travelled there by steamboat from Quebec City. The outstanding citizen, Napoleon Comeau, was guardian of the Godbout River, a fine salmon stream, well known to Montreal anglers. He held virtually every civic office in the village and was a remarkable naturalist. Without his aid we should never have had such good collecting as we did in both fish and Odonata. The locality was typical for northeastern dragonflies and I was fortunate in taking a fine series of Somatochlora cingulata, the large robust species of the north. At the request of the "lairds" of the Godbout River, M. Comeau wrote a remarkable book on his experiences in this region, entitled Life and Sport on the North Shore.

The western trip, made in 1921 with Professor R. B. Thomson of the Department of Botany and Mr. Kurata, was the most exciting and, at the same time, the most aggravating of all the trips $I$ have made. Professor Thomson had invited us to join him in a trip by motor-car to Banff, Alberta. His car was a Model-T Ford, one of none too recent vintage, but, as he described it, in "rattling good shape." We carried two tents, a number of large dunnage bags, which rested on luggage carriers, clamped to the running boards, and roped to the sides of the car. The outfit when packed looked as though it were destined to experience adventures, and this impression proved to be a correct one.

In those days well-paved highways were infrequent even in the Middle States. In Western Canada they did not exist. We travelled through Michigan to Chicago and then northward through Wisconsin and Minnesota, entering Manitoba at Emerson. Many were the disasters we experienced: almost daily there were blow-outs; we broke the universal joint in Manitoba; dumped the car sideways into a pond in Saskatchewan; and so on ad infinitum. Some travellers say the prairies are monotonous. There was never a chance for monotony on this trip. How we ever reached Banff is an insoluble mystery, but we did, although it took us a month. At Banff we separated and for a time went different ways.

Discoveries regarding Somatochlora and the finding of the haunts of rare species were so rewarding that the mishaps of the auto trip were almost forgotten. Leaving Banff, I travelled west and south 
along the Arrowhead Lakes to Nelson and had a few pleasant days with my old friend Frank Whitehouse, who worked mainly on the dragonflies of British Columbia.

In April, 1922, the School of Graduate Studies at the University of Toronto was opened and the direction of graduate students became more definitely organized. Except for a full-time secretary all the work of the School was taken on by members of the teaching staff, who were already fully employed. The number of graduate students increased greatly and in many departments, including Zoology, the additional work assumed by the staff was considerable. I felt that I was not doing justice to my position in the Museum of Zoology and therefore tendered my resignation as assistant director and was succeeded in 1931 by Professor J. R. Dymond. It was at this time that I assumed the position of an honorary curator in the Museum.

Meanwhile, I continued to make occasional summer collecting trips, but depended for my material from distant regions mainly on the collections made by others, notably the Museum expeditions made almost annually until the entire Province had been covered in a general way from Point Pelee, Lake Erie, to Fort Severn, Hudson's Bay.

In 1934, Dr. Bensley died suddenly. Dr. W. H. Piersol, professor of Histology and Embryology, and I were asked to carry on in his place for the balance of the term. I was then appointed head of the Department. I continued my senior courses, such as the course on invertebrate systematics, the courses on Arthropoda and entomology, as well as the third year of the pass course. My other courses had long since been taken over by younger members of the staff. Most of my collecting and observation of dragonflies was now done in the environs of my summer residence on Lake Simcoe. Several pleasant and successful trips, however, were made in southern Ontario with my friend and colleague, Dr. John Oughton, formerly one of my students in Honour Biology, later a member of the staff of the Royal Ontario Museum of Zoology, and now professor of Invertebrate Zoology in the University of Guelph. At the Museum he was a specialist in the Mollusca and it was these animals that he was collecting on our trips in 1934, 1935, and 1936.

Before I became head of the Department of Zoology in 1934, I had been very conscious that our curriculum was overloaded on the morphological side. We needed general physiology. The opportunity to introduce this subject came almost immediately after my appoint- 
ment as head, when a staff member of the Medical Department of Physiology [Dr. Laurence Irving], whose main interest was in the physiology of aquatic animals, was transferred to the Department of Zoology. Physiology has since become an important subject in the Department of Zoology.

During World War II the Department of Zoology carried on much as usual except for adjustments that had to be made owing to the absence of members of the staff who had joined the armed forces.

In 1948, I retired as head of the Department of Zoology to be succeeded by Professor J. R. Dymond, but was appointed a special lecturer for the following year to give my advanced course on Arthropods. In 1949 I moved to the Royal Ontario Museum, where an office in the Department of Entomology had been reserved for my occupation. My collection of Odonata had been donated to the Museum and was delivered there at the time I moved into my new office.

\section{INVESTIGATOR}

My earliest papers were faunistic notes on Ontario Orthoptera, beginning in 1897 with the Acrididae and continuing with the other saltatorial families. W. S. Blatchley was my first correspondent, but within a year or two I had added S. H. Scudder, A. P. Morse, and A. N. Caudell, and soon afterwards one or two others, notably J. A. G. Rehn.

My early records were published because they were nearly all new to Ontario, if not to Canada. Another incentive to publish arose from the events of a collecting trip made with Professor John Macoun in southern Ontario in the summer of 1901. We met at Point Pelee and visited various stations along the shore of Lake Erie and Lake Huron. At the Lake Erie stations, especially Point Pelee, a number of Orthoptera were found which were well known in Indiana and other localities south of the border, but had never been reported from Canada. From the nature of the vegetation this was not surprising. The strip along Lake Erie from Niagara to the St. Clair River is a bit of the Carolinian Zone, the only part of Canada where such trees as the tulip, black walnut, sour gum, and flowering dogwood are found in a wild state.

My most interesting discovery on this trip was a new species of Trimerotropis on the beach of Lake Huron at Southampton. It 
appeared to replace the Sea-beach Grasshopper (T. maritima interior) which we found in abundance everywhere on the Lake Erie beaches.

Probably my most significant paper of this period, published in 1903, was entitled The Genus Podisma in North America. It showed that the two wingless grasshoppers of the genus Podisma (subsequently placed in Zubovskya and recently in Boonacris), $P$. glacialis Scudder of the White Mountains, and P. variegata of the mountains of New York and Pennsylvania are both found in Ontario but are connected from north to south by intergrades together with some change in habitat. The problem now appears, however, to be more complex than a simple cline.

I continued to publish faunistic papers on Orthoptera for about eight more years, but the only one of general interest is the paper reporting the discovery of a completely new type of orthopterous insect representing a new family (in fact at least a new suborder). This was the now well-known Grylloblatta campodeiformis, first found in 1913 on Sulphur Mountain, Banff, Alberta. This discovery, so remarkable, was to turn my interest in Orthoptera into a new direction. Only two specimens were found, both females, but I knew that the combination of running legs, segmented cerci, and exserted ovipositor was unique. The male remained unknown until 1919, when I obtained for description an adult male and immature nymphs of both sexes from the Banff Museum. Other unique features were found in the male genitalia and the combination of interesting characters found in the two sexes was so remarkable that it was almost inevitable that I should be drawn into a comparative study of the terminalia of orthopteroid insects. This study appeared in two parts, the first on the female structures in 1919, the second part on the male structures in 1922. These studies threw some light on the homologies of these extremely variable and often complex parts, and revealed other features of Grylloblatta which are more primitive than those of any other Orthoptera.

Beginning in 1924 Dr. Norma Ford (now my wife) made several trips to the Rocky Mountains of Alberta and collected Grylloblatta in numbers, bringing them home in glass jars containing moss and packed in ice to keep them at a temperature as near zero centigrade as possible. She was studying their habits and reactions to temperature changes and following through their life history, which proved to be extremely long.

I entered upon an extensive study of the anatomy of this insect, the 
results of which appeared in five parts; parts 1 to 4 in the Annals of the Entomological Society of America, and part 5 in the Canadian Journal of Research. These studies dealt with the exoskeleton and musculature of the various body regions, the last one with the digestive organs. The nervous and reproductive systems I was unable to undertake, but the former has been carried out by Dr. H. H. J. Nesbitt of Carleton University, Ottawa.

A general account of Grylloblatta was published in 1937 as my presidential address to the Biological Section of the Royal Society of Canada. Most of the material on the life history had been worked out by my wife. It should perhaps be explained that this insect is of great interest from two points of view, although these are interrelated. Firstly, it is evidently a very archaic insect which has retained many primitive characters; secondly, it is decidedly stenothermal being intolerant of ordinary room temperatures and of temperatures below minus 10 degrees centigrade. Its metabolic rate is extremely low, for its development requires at least seven years under laboratory conditions. It is also peculiar in having an unpigmented instar between the last nymphal stage and the adult.

While my interest in the systematics of Orthoptera was still keen I was becoming more and more attracted to dragonflies, which I was constantly observing on the various canoe trips that I made in the summer in the Muskoka and Nipissing Districts. But it was also Dr. J. G. Needham's vivid word pictures of dragonflies on the streams and bog ponds of the Adirondacks that influenced me to add the Odonata to the Orthoptera as my specialty. After all, these two orders together would make only a small fraction of any one of the larger orders.

I soon discovered that the dragonflies were even less known in Canada than the Orthoptera. The larvae or nymphs had received little attention except from Cabot and Needham, whose pioneer work had made known most of the genera and a number of species, but no complete life history of a North American dragonfly was known at that time.

I soon found that there was much to learn about our local Odonata in both larval and adult stages. My first discovery was made in 1904 while I was investigating Grenadier Pond, a small lake in High Park, Toronto. Here I picked up my first Gomphus nymph, which had crawled out upon a water-lily leaf. I put it in a paper bag and in a few minutes the imago had emerged. Finding several more of these 
nymphs and consulting Needham's work, the species proved to be G. furcifer, whose nymph was unknown. Thus my first paper on Odonata was a description of this new nymph.

My first new species of Odonata was taken on Lake Simcoe and was a Somatochlora. Correspondence with the late E. B. Williamson elicited the fact that he had also found the same species in northern Michigan and believed it to be new. Having seen my sketches of the anal appendages of this insect, he generously insisted that I should describe it. Accordingly, I named it after my distinguished colleague Somatochlora williamsoni. This was the beginning of a long and valued correspondence with a remarkable and lovable personality, who became one of my closest friends.

In 1907, I first went to the Great Lakes Biological Station as curator. This was located on an island in Go Home Bay, Georgian Bay, Ontario, and was a delightful place for a naturalist but too far from running water to be a good site for a biological station. I was sent there without directions or plans. I had a staff of four or five students, all of them eager for work, but we were all too inexperienced to do much besides collecting and rearing aquatic animals of various kinds, chiefly insects. Dragonflies were emerging in the marshy bays, channels, bog lakes, and even on the more exposed rocky shores. I saw more of the habits of dragonflies at Go Home Bay in the three summers I spent there than I have ever done since in any locality. We produced one volume of papers in 1915, but following the outbreak of World War I, the station was closed and never reopened.

During this same period but beginning several years earlier, I had been taking particular notice of the large blue-spotted or green-spotted dragonflies of late summer belonging to the genus Aeshna, and discovered that there were obviously more species at DeGrassi Point alone than were accountable for in the literature. Williamson, who made a trip in 1907 north of Sault Ste. Marie, Ontario, returned with four distinct species, none of which could be determined with certainty. We compared notes, and Williamson suggested that I undertake a revision of the genus. I willingly assented to this proposal and worked on it for about five years, finishing the monograph in 1912. I examined all the available collections in North America and described a number of new species, redefining those already described. I was fortunate in obtaining also nymphs or exuviae of nearly all the species. This work was illustrated in part by coloured plates, since the colour patterns, which had hitherto been largely ignored, were 
found to be very useful taxonomically. Other valuable characters were discovered in the genital hamuli, which formerly had been overlooked.

I continued to publish numerous papers on Odonata, chiefly descriptions of previously unknown nymphs, revisions of nymphs of various genera, and annotated lists of the Odonata of various Canadian provinces.

An unexpected deviation from my usual routine took place in June, 1919. Two cases of cutaneous myiasis in infants were independently brought to my attention. I recognized the larvae as belonging to the Sarcophagidae, but could not identify them further. From the second case, however, a few larvae had been removed alive and these were put on raw beef and in due time produced four flies, which I identified as Wohlfahrtia vigil. It was the first time anything had been known of the habits of Wohlfahrtia in America, although a European species ( $W$. magnifica) was well known to infest wounds or enter the natural passages of persons sleeping in the open. I wrote preliminary papers on these case of cutaneous myiasis and after securing further material my wife took over the study of the life history of the fly, including its larviposition on a young mouse and the complete rearing of a second generation. My later work on Wohlfahrtia was confined to a detailed description of the three larval stages. Subsequently much has been published on $W$. vigil, which is normally a parasite of various small mammals and is sometimes troublesome on fur farms.

This was the middle part of my career when my research was most varied, but the study of dragonflies, beginning as a hobby, continued to dominate my interest and does so up to the present.

It was natural that I should become specially interested in the corduliid genus Somatochlora, because it is a predominantly Canadian genus, rarely found in collections. It was soon evident that some of the species had been described too briefly from odd specimens taken in remote northern localities and were unrecognizable except by comparison with the type specimens.

On the genus Somatochlora I worked for years. Specimens were obtained from missionaries in Labrador and I collected material myself from relatively northern localities across the Continent from Newfoundland to Prince Rupert and Vancouver Island, British Columbia, and also received specimens from mountainous parts of both eastern and western United States. I succeeded in rearing one species from the egg, although I had to publish my results two years before completing the rearing. From all the data collected, I wrote a monograph 
similar to my earlier one on Aeshna, this was likewise published as a University of Toronto study in 1925.

When the time came for my retirement, I finished my last paper on Grylloblatta (the organs of digestion) and decided with regret that this series must be completed by someone else.

Some years ago I decided that the data we now have on the taxonomy and distribution of Canadian Odonata should be collected and put into a more convenient form for others working in this field. I proposed to prepare a book with keys to the adults and also to the nymphs, descriptions of both adults and nymphs, and as much ecological data as could be brought together. Preparation of this monograph became the object of my retirement years at the Museum. The first volume was published by the University of Toronto Press in 1953 and the second volume in 1958. The third and final volume is in course of preparation. 


\title{
Professor of Zoology
}

\author{
J. R. DYMOND
}

The justification for a university is that it preserves the connection between knowledge and the zest of life, by uniting the young and the old in the imaginative consideration of learning. The university imparts information, but it imparts it imaginatively. At least, this is the function which it should perform for society. A university which fails in this respect has no reason for existence. This atmosphere of excitement, arising from imaginative consideration, transforms knowledge. A fact is no longer a bare fact: it is invested with all its possibilities.

ALFRED NORTH WHITEHEAD, The Aims of Education

FATE WOULD have had to answer for gross misuse of talents had Edmund Walker not been a professor of zoology. For him, there was fascination in all living things and to a remarkable degree he was able to communicate his excitement about them to others. His considerable ability as artist, musician, and mimic enabled him to impart information with full appeal to imagination. Certainly he belonged in Whitehead's kind of university.

As far as formal lectures were concerned, Edmund Walker's were much like he was himself-quiet and gracious. They lacked the forceful impact which a more dominating personality might have brought to them, but his own assets were a far rarer gift. Biology was not just Edmund Walker's profession, it was his life; and when he taught about the structure or habits or evolution of animals, it wasn't difficult

1 [Professor Dymond died a few months after completing an original outline for this section. This article has been prepared by the Editor of this volume, incorporating many of the ideas expressed in that outline.] 
for students to sense that here was something tremendously important which man had learned about the natural world. For him it was. And as he talked to them with this quiet enthusiasm, the students saw materialize, from seemingly careless outlines on the blackboard, creatures of many kinds, but all with the subtle essence of life. And if the creature was capable of producing sound, as were his favoured Orthoptera, Dr. Walker could supply that, too, for he had an easy way with sounds. But he had mastered yet another art, conveniently so because most invertebrates are mute, and stepping out from behind the image of a bearded and precise professor of zoology, Dr. Walker could concentrate his considerable personal charm into the stalking movements of a praying mantis or the moulting behaviour of a crayfish. It was not difficult to understand why he was a favourite with students.

Another of the features which illuminated his lectures was a reverence for life. It is a popular conception that a zoologist's familiarity with animals has for him robbed life of its wonder. Far more likely it is that the greater one's knowlede of animals becomes, the more marvellous life appears. Certainly this was true of Dr. Walker. A story which illustrates his respect for living things concerns his disposal of a few living mealworms left at the end of a laboratory period. Instead of throwing them on the floor and crushing them, as one with less understanding and feeling might have done, he carried them up two flights of stairs to restore them to their place in the vivarium. $\mathrm{He}$ was then over 60 years of age.

Dr. Walker was not a text-book teacher. Somehow he had accumulated an immense store of information about the morphology and ecology of the animals about which he taught, and these facts he could interpret and relate with ease in a wide variety of situations. Many of the invertebrate specimens used in his classes were ones which he had collected himself in field excursions over much of Canada. The particular habitat and other circumstances of collection were usually very much a part of him, and furthered the sense of personal identification which Dr. Walker had with his subject.

Yet, for all his ease with lectures, it was not always that way. Dr. Walker began lecturing to students in the fall of 1906, and he has told with amusement of the trials of that first lecture in Room 101 of the old Biology Building. His fingers, groping for some solid support along the edge of the table, made contact with one of the empty electric light sockets. Up shot his arm, and a roar of laughter greeted the 
performance; proceeding with his lecture with even less assurance than before, to his extreme embarrassment he managed to do the same thing again.

Zoology at Toronto has a long tradition of orientation toward aquatic animals, and it is interesting to see that even the first entomologist on the staff made his major contribution in studying the Odonata, a group of aquatic insects. The tradition appears to have begun with Professor Ramsay Wright who, some years before the turn of the century, saw clearly the importance to Canada of its aquatic resources. In 1874 Professor Wright was one of a group of Canadian zoologists making representations to the Federal Government on behalf of a marine biological laboratory. And in 1892 he published a Preliminary Report on the Fish and Fisheries of Ontario, again urging the need for an organized investigation of these aquatic resources. Out of these representations there developed the Biological Board of Canada, which later became the Fisheries Research Board. The Great Lakes Biological Station was set up by the Biological Board at Go Home Bay in Georgian Bay, Lake Huron. During its short life, from 1901 until 1914, this station, which was in operation only during the summer months, was staffed largely by professors and students from the Department of Biology of the University of Toronto.

Dr. Walker was curator of the Station in 1907, 1908, and 1912. His interest in Odonata had already begun before his arrival at Go Home Bay, but his periods there were clearly an important part of his own field studies: "I had a staff of four or five students, all of them eager for work, but we were all too inexperienced to do much besides collecting and rearing aquatic animals of various kinds, chiefly insects. Dragonflies were emerging in the marshy bays, channels, bog lakes, and even on the more exposed rocky shores. I saw more of the habits of dragonflies at Go Home Bay in the three summers I spent there than I have ever done since in any locality." Among these students was W. A. Clemens, then a recent graduate in biology from Toronto, and Dr. Walker's first graduate student. Following Walker's suggestion, he began to study mayflies at the Great Lakes Station, and completed his M.A. work on that group. After receiving his PH.D. from Cornell, Clemens joined the staff at Toronto and took charge of the newly created Ontario Fisheries Research Laboratory. This was another product of the aquatic stimulus which flourished at Toronto, and was immensely successful in producing the limnologists and fishery biologists that were needed in Canada during the period of 
very rapid development in this field. The Laboratory was actually organized within the Department of Biology in 1921 by Dr. B. A. Bensley who was then head of the Department and was very conscious of the need for scientific investigation of the fresh waters of Canada. Clemens went to British Columbia in 1924, first as director of the Pacific Biological Station, and subsequently became head of the Department of Zoology at the University of British Columbia. He became very active in the fields of limnology and fisheries biology and later recorded that it was the experience at Go Home Bay with Dr. Walker which marked the commencement of his life-long interest in aquatic biology.

Through his long career a very great many other students came to know Dr. Walker, too; some as undergraduates, others as graduate students. In universities and government laboratories there was scarcely a section of Canada in which there was not a biologist, often several, with fond memories of valued associations with him.

The flavour of Dr. Walker's courses in invertebrate morphology for graduate students has been recalled by Dr. C. E. Atwood, now a staff member of the Department of Zoology at Toronto: "... I expected time-tables, set lecture and laboratory periods, conflicts, tests, etc. One morning my instructor came in, his arms full of vials of lower Crustacea topped by a few books, dumped them on my table and said: 'See what you can make of these.'. . A few days later I heard steps coming down the corridor to the accompaniment of $A v e$ Maria whistled and hummed in harmony at the same time. My instructor came in, with more bottles. From a few casual questions, he apparently gained the impression that I had perhaps not squeezed the last traces of morphological knowledge from the corpses of the unfortunate shrimps, for he sat down on my table, fished a little red and white striped bridge score pencil out of his pocket and began to talk, illustrating his remarks with drawings as he talked. After a few minutes of this performance, my eyes, I am sure, had acquired that stalked appearance which I afterward learned to associate more particularly with certain Malacostraca. However, I gradually gained courage to begin asking questions and after a couple of hours my instructor leaped from his seat and hurried out, looking anxiously at his watch. This general procedure continued for two years, covering the Invertebrata and the Insecta. Sometimes the discussion strayed from the anatomical details of the creatures in my dissecting tray to their habits, where they had been caught, and to many other zoological and non- 
zoological subjects. It gradually dawned on me that I was getting something from these courses which was not covered by the Graduate Calendar specifications."

Invertebrate zoology at the University 'of Toronto progressed in a manner that was largely parallel to E. M. Walker's own career. His was the first staff appointment in this field. In distinction from the practice in many other universities, entomology never was set apart from zoology as a separate department at Toronto. Beginning with a new course in invertebrate zoology, Dr. Walker went on in subsequent years to introduce courses in forest entomology, parasitology, and general entomology, the former two taken over in subsequent years by newer members of the University staff. General entomology has remained, at Toronto, a fourth-year option for students of the Honour Biology course. Other courses given by Dr. Walker were Invertebrate Zoology to third-year students in the pass course, and an introduction to the systematics of the invertebrates to students in the Biology course. Of these he has more to say in his autobiographic sketch.

But the course for which he became best known was one that reflected more closely his own interest in the morphology and phylogenetic relationships within the Arthropoda. This course, Advanced Invertebrate Zoology, was scheduled for the third-year students of the honour course in Biology, but the class usually included a number of graduate students as well. There seems little doubt that it was because he was familiar with the marine, terrestrial, and fresh-water representatives from his own field experiences that the inter-relationships of the arthropod classes did have an appeal for him. And there is also little doubt that it was this broad interest and teaching experience in comparative morphology of the arthropods which gave Walker's published work in systematics much of the authoritative competence which was its characteristic. His two long papers on the terminal abdominal structures of orthopteroid insects (1919b and 1922b), and his extensive treatment of the structural features of the Odonata (1953), illustrate clearly a command of comparative morphology. And there were others too $(1931 \mathrm{a}, 1932 \mathrm{a})$. Indeed, his immediate recognition of the highly unusual structure of Grylloblatta from the first specimens he saw can be attributed directly to this early interest and experience in comparative morphology; and his series of papers on the anatomy of Grylloblatta campodeiformis (1931b, et seq.) is an outstanding example of morphological work. Thus, although primarily a systematist in his own research, Walker had the advantage, 
enjoyed by very few systematists, of being a recognized morphologist as well.

Proceeding concurrently with his courses was his research which was largely in systematics. His early contributions to the study of Orthoptera were mainly of a faunal and distributional nature. But when he began to work on the Odonata, a new problem was immediately encountered: the systematics of life-history associations. The aquatic nymphal stages of dragonflies are separated from the adults by such wide gaps of structure and habitat that unequivocal establishment of the connection between the two stages for each species requires diligent field work and a knowledge of taxonomic characters in both larval and adult stages. This kind of systematic work had scarcely begun on North American Odonata when Walker began to work, yet it had to be accomplished before anything could be learned about the early life-history and even the habitat for each species. The fact that most of the species of Canadian Odonata are now recognizable in the larval stages is due in large measure to the attention given by Walker to this aspect of systematics. And it is not only that this kind of work enables one to identify the larvae in their precise habitats, but also that a knowledge of the comparative morphology of the larvae at the species level brings a new body of evidence to bear on the evolutionary history of the Odonata. In search of this information, Walker's field work during the summer recess of classes took him over the whole of Canada from Newfoundland (long before it was part of Confederation) to Vancouver Island. Some of his field work was combined with expeditions of the Museum; much was of his own arranging. And, of course, DeGrassi Point on Lake Simcoe, the family's summer home, was an outdoor laboratory for most of his life.

The desire to recognize individual species of living things, to classify them, and to understand their phylogenetic relationships, was, in fact, so much a part of Dr. Walker that each summer for relaxation he would try to master the local representatives of some new group of organisms. In this way, he became familiar with the Ontario species of molluscs, isopods, asters, grasses, and goldenrods, to mention a few groups, and in fact, published papers on the first two (1917a, 1927a, 1928a). His over-all competence as a field botanist came to be highly regarded by his associates.

From among other aspects of invertebrate zoology which came to his attention quite fortuitously, Dr. Walker became especially interested in the immature stages of the fly Wohlfahrtia vigil. These had 


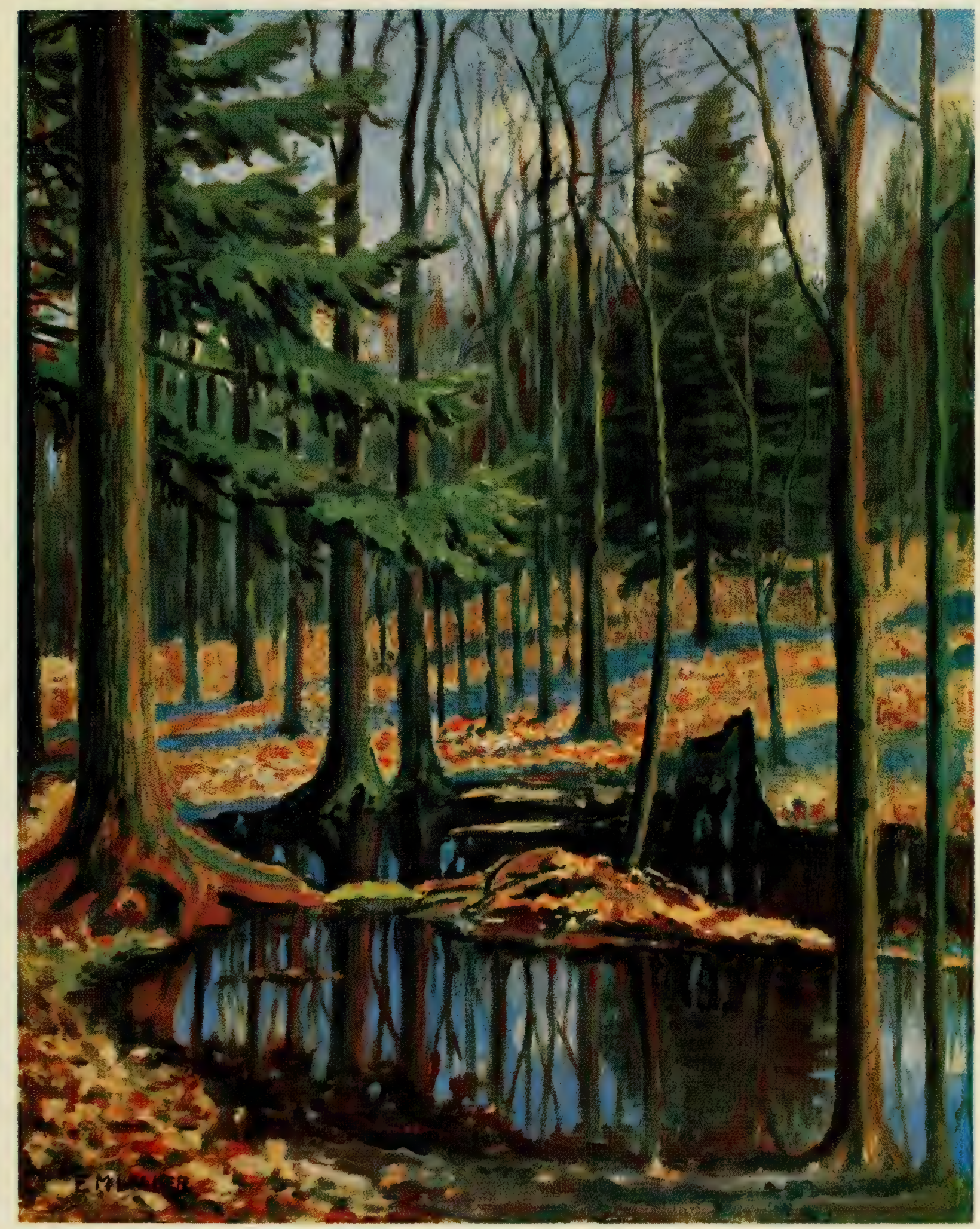

FIGURE 5. Spring pools in the bush, by E. M. Walker, c. 1950. 

not previously been described, and it was a matter of considerable interest that they first came to notice as facultative parasites of human infants. He published several papers on the morphology and lifehistory of this species and on the cutaneous myiasis caused by the flies (1920b, 1922c, 1931c, 1937b).

His progress through the hierarchy of the Department of Zoology was not rapid: lecturer, 1906-1913; assistant professor, 1913-1917; associate professor, 1917-1926; professor, 1926-1948; (and professor emeritus from 1948). In 1934, following the death of Dr. B. A. Bensley, the Head of the Department, Dr. Walker was appointed to take his place, and he remained in that position until 1948, when he retired. The headship rested rather uncomfortably with him for he did not readily sense the satisfactions of organization and administration. But what did indeed grace the office for his tenure of it was his personal example as an inspiring teacher and internationally recognized scholar. His enthusiasm for all living things, his broad cultural interests, and his gentle personality endeared him to colleagues and students alike.

In addition to Dr. Walker's obligations to the University in the Department of Zoology and to the Royal Ontario Museum, he served as editor of the Canadian Entomologist from 1910 until 1920. And throughout the course of his career, because of the mounting volume and significance of his published contributions to invertebrate zoology, he was called upon to accept many positions of responsibility and honour. He served as president of the Entomological Society of Ontario from 1910 to 1912 , and was elected one of the first Fellows of the Society. ${ }^{2}$ In the Entomological Society of America he served as vice-president in 1917, president in 1939, and later was appointed an honorary member. He was one of the first to receive honorary membership in the newly constituted Entomological Society of Canada in 1958. He was appointed an honorary member of the Royal Canadian Institute, and served as honorary editor from 1924 until 1945. He became a Fellow of the Royal Society of Canada, served as president of Section V in 1936, and was awarded the Society's Flavelle $\mathrm{Medal}^{3}$ in 1960 for outstanding work in science. He was appointed a corresponding member of the American Entomological Society and of the Academy of Natural Sciences of Philadelphia in 1950. For the

21964. Centennial of Entomology in Canada, 1863-1963: Proceedings of a commemorative joint meeting of the Entomological Society of Canada and the Entomological Society of Ontario. Canad. Ent. 96(1-2): 475 pp.

31960. Proc. and Trans. Roy. Soc. Can., 3, 54:56. 
Tenth International Congress of Entomology, held in Montreal in 1956 , Dr. Walker was an honorary vice-president. His Grylloblatta campodeiformis was the official Congress emblem. In the newly formed Canadian Society of Zoologists he was appointed an honorary member in 1962. And most recently, the degree D.Sc. honoris causa was bestowed upon him by Carleton University in 1963 (see Fig. 4). ${ }^{4}$

He was also active in organizations of naturalists, became a founding member and president of the Toronto Field Naturalists' Club, and served both as president and director of the Federation of Ontario Naturalists. And for a number of years Dr. Walker attended the Summer Nature Camp of the Federation of Ontario Naturalists as a group leader (see Fig. 9).

When, in 1948, he officially retired from the Department, an especially warm tribute was paid to Dr. Walker by his many colleagues and former students. Presented to him at a special dinner in his honour was a bound volume containing their letters of appreciation for his example of inspired scholarship, and their warm wishes for a happy and satisfying retirement. The opening page of that volume establishes well and clearly the niche in their affections which he had come to occupy:

To

Professor Edmund Murton Walker

on his retiring from the Headship of the

Department of Zoology, University of Toronto, in 1948

All that he has meant in diverse fields as scientist, teacher, friend and stimulus to biologists over many years can never be fully told, but this volume of recollections and thoughts, perhaps even flights of the imagination, from many sources, has been prepared in the hope that it may from time to time revive memories of happy episodes in many places, and still more, reveal to him, even if incompletely, how deeply his wide and firm hold on essential values has impressed those who have for longer or shorter periods come under his influence.

In his hands biology is greatly a science and no less greatly a humanity.

${ }^{4}$ Canad. Ent. 96(1-2): 475 pp. 


\title{
Curator, Royal Ontario Museum
}

\author{
GLENN B. WIGGINS
}

In 1918, I became definitely a member of the Museum staff, having been appointed assistant director of the Royal Ontario Museum of Zoology.

E.M.W., "Autobiographic Sketch"

THROUGHOUT EDMUND WALKER's long career he had an enduring personal interest in the museum world. This was not only because his own research in systematics and morphology coincided with the museum tradition; it was also because he understood the function of museums in the natural sciences. So close was his own identification with museums, that he took up the first opportunity to become personally involved, even though he had other full-time responsibilities, and for much of his working life that involvement was continued.

He has already recorded in his autobiographic sketch, how, after deciding to return to his major interests in the field of biology, he spent the year 1904-1905 in the Department of Biology of the University of Toronto with Professor Ramsay Wright. Among other duties he began to rearrange and enlarge the department's insect collection which was then a part of the University's biological museum. In the report for that year, of the president of the University, it was written that Dr. E. M. Walker was supervising the cataloguing and the arrangement of the Department's insect collection, and it was urged that "... some permanent provision must be made in the near future for the diagnosis, cataloguing, arrangement and display of our zoological collections, the time of the various members of the staff being wholly occupied by the largely increased demands in teaching."

Events even then in motion were to make this "permanent provision" a reality. Thinking by certain individuals had for some years 
been advancing toward the goal of a new provincial museum in Toronto. Finally, the provincial government and the University of Toronto agreed to share the cost of a museum, and by 1913 construction of the first wing of the Royal Ontario Museum was nearing completion. Separate museums of Archaeology, Palaeontology, Geology, and Mineralogy were established within the one building, and finally a museum of Zoology. ${ }^{1}$ Dr. B. A. Bensley succeeded Professor Ramsay Wright when he retired as head of the Department of Biology in 1912, and the Royal Ontario Museum of Zoology was established by the Board of Trustees at Dr. Bensley's request. Because the directors of these museums were for the most part the heads of the corresponding departments in the University, Dr. Bensley became the first director of the Museum of Zoology. Dr. Bensley, a comparative anatomist, filled both positions until his death in 1934 .

Because it had been the last of the constituent museums to be created, the Museum of Zoology was without staff or gallery exhibits when the new building was dedicated in March, 1914. In 1915, under Dr. Bensley's supervision, materials were selected from the University's biological museum and were transferred to the new Museum of Zoology. These added to the holdings of several other institutions in Toronto, including the Provincial Museum and the Royal Canadian Institute, formed the nucleus of the zoological collections. Mr. T. B. Kurata was assigned from his work in the Department of Biology to assist in the preparation of exhibits for the Museum of Zoology, and he became the first full-time member of the Museum staff. Space assigned to zoology was located at the north end of the original wing on the third floor, in what is now part of the Chinese gallery. The original gallery exhibits were installed here. ${ }^{2}$ The insect collection was housed in a room partitioned off from this gallery. Space for a preparation laboratory and storage for specimens in fluid was made available on the ground floor in what is now one of the ethnology rooms.

Here, then, was a museum. There were few enough biologists anywhere in the University at that time, but if the new Museum of Zoology were to prosper some of them had to feel a sense of personal identification with its aims. Fortunately both Bensley and Walker saw the potential for an institution which was worth their best efforts. In

${ }^{1}$ A more complete account of these early events is given in: Dymond, J. R. 1940. History of the Royal Ontario Museum of Zoology. Contrib. Roy. Ont. Mus. Zool. no. $18,52 \mathrm{pp}$.

${ }^{2}$ A photograph of this early gallery is given by Dymond, 1940, op. cit. 
his autobiographic sketch, Dr. Walker says: "Although I had at first no official connection with the new Museum, I felt that it was my responsibility to build up the collection of invertebrates, and I was also interested in developing a collection of casts of our native fishes. Because of a criticism I had heard of the miserable little handful of fishes we had to start with, I was determined that ours should become one of the finest collections of fish casts in Canada. I arranged with $\mathrm{Mr}$. Kurata that we would work together and make a number of trips combining the collecting of fishes and Odonata, an order of insects which had been neglected in Canada and in which I was especially interested."

Some account of their first trip to Vancouver Island in 1913 has already been given by Dr. Walker in his autobiographic sketch, and as he recounts, it was during this trip that they discovered the first specimens of Grylloblatta at Banff, Alberta. Mr. Kurata possessed remarkable technical skill and ingenuity, qualities which were well suited to the needs of the Museum in its early years. He remained with the Museum until his retirement in 1952, and among many other contributions, built up an important study collection of native spiders and wrote several papers on Ontario species. Towards the end of 1915, Mr. E. B. S. Logier was engaged to assist Dr. Walker by painting the casts of fish and by preparing other types of exhibits. He assisted also in the care and enlargement of the collection of insects. Mr. Logier remained with the Museum until his retirement in 1961, and in addition to his work as an artist, he built up an important research collection of amphibians and reptiles, and wrote two books and a number of scientific papers about these groups.

The early work of preparing exhibits for the new Museum, as Mr. Logier recalls, was carried on in the Biology Building until about 1917, when it was transferred to the Museum. Dr. Walker supplied most of the invertebrate specimens from his own collecting, and also from his correspondents, and under his direction the invertebrate exhibits were prepared by Mr. Kurata and Mr. Logier. Among other things, a series of invertebrate animals mounted on glass plates and preserved in fluid in museum jars was produced, as were displays of molluscs and a long systematic series of the common species of native insects. The insect display, filling some sixty trays, was largely arranged by Dr. Walker himself, and was retired from the gallery only in recent years. Mr. Logier recalls Dr. Walker's wide interest in all aspects of the work of the Museum of Zoology, and how, even after 
the work of preparing exhibits had been transferred to the Museum building, he would stop by several times each week to see how work progressed, and to leave recently acquired specimens to be mounted for the insect collection. It has to be remembered that the Museum and the Biology Department were situated at opposite ends of the campus, and that Dr. Walker was at the same time carrying out his obligations as a professor in the Biology Department. It was also during this period, 1910-1920, that he served as the editor of the Canadian Entomologist.

Having served the needs of the Museum on a basis entirely unofficial for its first five years, Dr. Walker's museum role then took a new form: "In 1918, I became definitely a member of the Museum staff, having been appointed assistant director of the Royal Ontario Museum of Zoology. During the next decade I made many summer collecting trips, usually with Mr. Kurata. These were made partly in the interest of the Museum and partly for my own research on the Odonata."

In the years between 1917 and 1939 there was a steady increase in the staff of the Museum of Zoology. This was the period when such men as J. R. Dymond, L. L. Snyder, F. A. Urquhart, J. L. Baillie, T. M. Shortt, J. G. Oughton, and C. E. Hope began the careers which were to have so much to do with the early development of the Museum. The field expeditions became combined operations serving a wide range of zoological interests, and E. M. Walker took part in many of them: 1919 to the Muskoka District of Ontario (see Fig. 6); 1920 to Point Pelee, Ontario; 1925 to St. Andrews, N.B., and to Lake Abitibi, Ont.; 1926 to Vancouver Island, B.C.; 1927 to Long Point, Ont.; 1931 to The Pas, Man., and Lake Nipissing, Ont.; 1935 to the Lake St. Clair area of Ontario; and 1936 to the St. Lawrence and Ottawa Rivers area of Ontario. The expeditions were of varying duration, and many extended to more than a month. Field expeditions Dr. Walker enjoyed immensely, and the somewhat reserved manner which often characterized his relations on the campus with associates was cast off. Colleagues on the early trips to Muskoka and Point Pelee recall him as the best of companions. Around the fire at night his monologues in full cockney accent were always in demand, and with his mouth-organ, E. M. took his place in the camp's musical group with L. L. Snyder, E. B. S. Logier, and N. K. Bigelow (see Fig. 6).

After thirteen years as assistant director, Dr. Walker, finding the burden of his teaching obligation becoming heavier, "felt that I was 
not doing justice to my position in the Museum of Zoology and therefore tendered my resignation as assistant director and was succeeded in 1931 by Professor J. R. Dymond." Professor Dymond had been secretary of the Museum of Zoology since 1922. Upon his relinquishing this formal responsibility for the Museum programme, Dr. Walker was given the position of honorary curator of Invertebrate Zoology.

When the newly constructed east wing of the Museum building was occupied in 1932, the collection of insects was moved to new quarters on the third floor, adjoining the south gallery, where it has remained. ${ }^{3}$ The transfer was made by F. P. Ide, who served as parttime curator from 1928 until 1936. For two years, terminating in 1936 , C. E. Atwood also did part-time curatorial work in the insect collection at the Museum. Both Dr. Ide and Dr. Atwood, now members of the staff of the Department of Zoology at Toronto, were graduate students of Dr. Walker at the time, and he arranged that a portion of the time covered by their appointment was devoted to work on the Museum collection. F. A. Urquhart was then given responsibility for the care of the collection, first on a part-time basis, and later as its first full-time curator. His work in Orthoptera was aided by Dr. Walker's own collection and library pertaining to this group, which were turned over to the Museum. Dr. Urquhart later became director of the Museum of Zoology, succeeding Professor Dymond in 1948, but is now a member of the staff of the Department of Zoology of Scarborough College. It was also Dr. Walker's interest in molluscs that led to Dr. J. G. Oughton's study in this group, and ultimately to his appointment to the Museum staff as a malacologist. Dr. Oughton is now on the staff of the Department of Zoology at the University of Guelph.

New duties were taken on when Dr. Walker was appointed Head of the Department of Zoology in the University in 1934, a position which he retained until his retirement. His keen interest in the Museum continued, and in the History of the Royal Ontario Museum of Zoology, published in 1940, ${ }^{4}$ Professor J. R. Dymond states: "Dr. Walker had much to do with the preparation and arrangement of exhibits, especially during the early years of the Museum's existence, and still continues to take an active interest in its development."

\footnotetext{
${ }^{3} \mathrm{~A}$ more extensive account of the origin of the insect collection of the Royal Ontario Museum is given by: Urquhart, F. A. 1938. The insect collection of the Royal Ontario Museum of Zoology. Canad. Ent., 70(4): 67-70.

${ }^{4}$ Dymond, J. R. 1940. History of the Royal Ontario Museum of Zoology. Contrib. Roy. Ont. Mus. Zool. no 18, 52 pp.
} 
AN ASPECT OF the Walker role often overlooked in the history of the Museum is that the very establishment of the Royal Ontario Museum was to a large extent the work of Dr. Walker's father, Sir Edmund Walker. In his chosen career of banking, Sir Edmund had risen from his first post as clerk to become General Manager, and later President, of the Canadian Bank of Commerce, and one of Canada's outstanding financiers. Through his deep personal interest in the broad field of education, combined with a remarkable ability to get things done, he became increasingly involved with many public enterprises. Among many other offices, he served as a member of the Senate, of the Board of Governors, and as chairman of the Board, of the University of Toronto; he was chancellor of the University from 1923 to 1924 when he died; he was president of the National Gallery of Art and largely responsible for the establishment of the Art Gallery of Toronto; he was president of the Toronto Conservatory of Music; he formed the Champlain Society. Details of these, and other, accomplishments of this remarkable individual are recounted elsewhere. ${ }^{5}$

The enthusiasm which Sir Edmund had developed for a museum was not at all vicarious, but was a natural development of his own very wide intellectual interest and experience. From his own father he had gained an appreciation of natural history and of the new and stimulating ideas of Charles Darwin. In early adulthood he took up his father's interest in invertebrate palaeontology, and for twenty-five years collected, identified, and exchanged fossils and brought together a library of some six hundred books and scientific papers pertaining to the subject. He was also keenly interested in archaeology. To him, the museum's function was clear.

In 1899, Sir Edmund had urged the establishment of federal and provincial museums in a paper presented to the Canadian Institute. During the next few years, he was in close contact with C. T. Currelly, and they were successful in securing an agreement that the archaeological materials being collected by Currelly in Egypt would ultimately be deposited in a single university museum. A Royal Commission on University Affairs was established in 1906 with Walker as Chairman, and the projected university museum was adopted. Plans were drawn up and the present site on Bloor Street tentatively chosen. Sir Edmund, who was at that time Chairman of the property committee of the Board of Governors of the University, and also a member of a museum committee which had been formed, urged the Board to begin imme-

${ }^{5}$ Glazebrook, G. P. de T. 1933. Sir Edmund Walker. Oxford Univ. Press. 160 pp. 
diately the building of one wing. He proposed that the Government of Ontario be asked to pay half the cost, and prepared the case for submission. A deputation headed by Walker presented the proposal to the Premier of Ontario in May, 1909, and was successful in gaining his support. Not long after this, construction was begun on the first wing of the present building. Sir Edmund was made first chairman of the Museum's Board of Trustees in 1912, and continued in this post until his death in 1924. In commemoration of his part in the origin of the Museum, a bronze bust of Sir Edmund Walker stands in the main rotunda.

THE FOURTEEN YEARS which Dr. Walker spent as head of the Department of Zoology brought many new responsibilities, and less time for research of monographic scope where his earlier work had been so effective. Retirement, when it came in due course, offered a solution, but a challenge, too. "In 1948, I retired as head of the Department of Zoology to be succeeded by Professor J. R. Dymond, but was appointed a special lecturer for the following year to give my advanced course on Arthropods. In 1949 I moved to the Royal Ontario Museum, where an office in the Department of Entomology had been reserved for my occupation. My collection of Odonata had been donated to the Museum and was delivered there at the time I moved into my new office. ... Some years ago I decided that the data we now have on taxonomy and distribution of Canadian Odonata should be collected and put into a more convenient form for others working in this field. I proposed to prepare a book with keys to the adults and also to the nymphs, descriptions of both adults and nymphs, and as much ecological data as could be brought together."

This ambitious goal became the dominant feature of Dr. Walker's years of retirement. He set himself a daily schedule which rarely varied: in the morning at the Museum, study of specimens and attention to correspondence; lunch with his wife, professor of Human Genetics in the University; in the afternoon, at home, a rest and a walk followed by work on the written part of the manuscript. For the fifteen years of his retirement spent in working on the three volumes of his monograph, Dr. Walker's daily attendance at the Museum was continued with hardly more than the normal lapses for vacation and brief illness. And there were results. When Volume I of The Odonata of Canada and Alaska was published in 1953, Edmund Walker was 76 years old. Five years later in 1958, Volume II appeared, and 
although this second volume was to have been the concluding one, it was clear that still a third would be necessary to cover the group in his accustomed manner. This he began at the age of 82 , and was able to complete much the larger part of the manuscript before illness forced him to give up his writing in his 86 th year. $^{6}$

His retirement years "in residence" at the Museum were as pleasant as they were productive. Having been one of the Museum's first supporters in the early days of his own career, Dr. Walker had returned as a distinguished scholar, and in his role as honorary curator was entirely comfortable. His associates returned the compliment. $\mathrm{He}$ attended social gatherings of the staff, and made himself a part of the organization in many ways. Always conspicuous by his distinguished bearing, he acknowledged this attention with friendly humility to all members of the staff, and became somewhat of an institutional landmark.

To the Museum's insect collection, which he himself had begun a half-century before, he brought a particular attachment. He was constantly bringing in specimens which "we ought to have in the collection." Even though he was in retirement, he considered himself to have the responsibilities of a member of the curatorial staff, and was always eager to lend his assistance to whatever task might arise. And it was typical of Edmund Walker that he should so often and sincerely express his appreciation for the provision that was made for him, as if he were the one indebted.

In spite of a concern about completing his work on the Odonata, his interests remained wide. A drawer of butterflies or beetles sitting on a table rarely failed to draw his close scrutiny, and often he would allow the stimulus to run full course as he recalled the salient features of systematic history and problems in this species or that. For the students privileged to be associated with Dr. Walker during these retirement years in the Museum, he was the oracle. For invertebrate systematics and morphology, his store of information was seemingly endless, and to season the facts he could add from his own acquaintance with many of the personalities involved. From his years of editing the Canadian Entomologist, he had a heightened sense of English usage and his criticism was both incisive and freely given. A

6It is cause for deep satisfaction to all concerned that Dr. Philip Corbet has agreed to collate the manuscript and to complete the unfinished portions of the third volume. 
keen interest in field botany had given him a strong background in the identification and distribution of plants. And he knew German with awesome fluency. To all of us, E. M. Walker brought a rich experience. As much a part of this as his knowledge was his impact as a person: distinguished appearance, upright bearing, scholarly concerns - a formidable image, to be mellowed delightfully when he responded to a friend's greeting with a broad smile and one of his charming accents. His relaxed contentment with the task at hand will not be forgotten by those who have heard, through his office door, the musical accompaniment whistled or tapped out with a pencil upon his teeth, a rare accomplishment which had brought him considerable notoriety among his University associates. His envy of those who kept a tidy desk was often expressed, and when a long-sought book or pen failed to appear (as was often the case), even after the overdue desk clearing, the mark of his deepest disgust was "Shucks."

Even though he followed closely his established working schedule, it was not without diversion. He accompanied his wife on a long trip to Europe, and there, for the first time, met many of his long-time colleagues and correspondents in the study of Odonata. Annually, there was the Christmas tradition of personally signing and adding appropriate notes to some 500 greeting cards. This was a longestablished Walker custom for keeping alive the many personal contacts established over so many years. The card was usually composed of a reproduction of his pen and ink drawings of the members of the household, dachshund included, often in some situation relevant to a high point in their year's activities. In latter years one Christmas somehow followed another a little sooner than before, and the pen and ink drawings were replaced by colour prints of one or another of the oil landscapes he had painted so well in earlier years (as, for example, Fig. 6). Summer vacations were spent at the family summer home on DeGrassi Point, Lake Simcoe, some forty-five miles north of Toronto. There, his undiminished interest and curiosity for native animals and plants provided a regular source of personal enjoyment and stimulation in his work. The stimulus led, in fact, to one highly interesting, and unscheduled, contribution.

It was at DeGrassi Point in 1890 that Edmund Walker had first begun to collect insects. His acquaintance with the area was both intimate and informed, as annually for the ensuing sixty years he continued his observations of the Orthoptera, Odonata, and certain 
conspicuous insects in other groups. The gradual disappearance of particular species of insects which had previously found their southern limit in the area, and its invasion by others of a generally more southerly distribution, was impressed clearly upon him as it could hardly have been upon others. These observations were made as a minor diversion for some years and were finally organized into an invitational address for the 1954 annual meeting of the Entomological Society of Canada in Sault Ste. Marie, Ontario. Under the stimulus of Dr. Fred Urquhart, then head of the Museum's Division of Zoology and Palaeontology, this paper became the catalyst for a series of contributions from several other departments in the Museum, which were published collectively as Changes in the fauna of Ontario (1957b).

A frustration he never could accept was that mounting years required him to restrict the field work which had always contributed so much to his studies. He was never particularly interested in exotic areas, but he did have an imposing list of parts of Canada which he longed to visit while he could. Canadian in both origin and orientation, Edmund Walker knew this country at first hand from Vancouver Island to Newfoundland, and in its fauna and flora he found more than enough to absorb his interest. Because he was familiar with so many native plants and animals at the species level, the dynamic aspects of geographic distribution and comparative ecology raised intriguing questions for him wherever he went.

And so his Museum years wore on, quietly, consistent with the man himself. Gradually he withdrew from active participation in organizations of all kinds. Manuscripts, drawings, the production of his books and papers were the abiding concerns. When the Museum celebrated the fiftieth anniversary of its founding in 1962, Edmund Walker was still contributing to its advance, as he had been at the beginning. Honours had come in these latter years from many sidesthe Flavelle Medal, honorary vice-presidency of the Tenth International Congress of Entomology, honorary membership in various societies. All of these he appreciated, but it would have taken some serious searching on his part to produce a complete list of these many acknowledgements of his contributions to biology. There could, however, be little doubt that a high point in his career was the award by Carleton University of the degree Doctor of Science honoris causa during the celebration of the 100th anniversary of the founding of the Entomological Society of Canada in 1963 (see Fig. 4). When the 
first public announcement of this award was made by Dr. George Holland during the opening of the Royal Ontario Museum's own special exhibition marking the Centennial, Dr. Walker was present to receive from the guests their burst of affectionate and enthusiastic applause. He was then 87 years old, somewhat uncertain of balance, still erect and unmistakably a distinguished scholar. As he stood to acknowledge the ovation from so many of his friends, it was entirely appropriate that he be accorded this sincere expression of good-will in the Museum to which he had for so many years contributed so much.

THE ROYAL ONTARIO MUSEUM of to-day has known many changes in its first fifty years. In place of the original constituent and separate museums, there are now some twenty co-ordinate academic departments and thirteen service departments. The collections and exhibits range over the world, as does the staff. These achievements are to-day realized only because some individuals believed in the museum idea and devoted their talents and energies to much less resounding beginnings fifty years ago. Edmund Walker was one of these. His varied talents, his high academic achievements, and his unique personality are not often the gifts of one man. These gifts he enlisted in support of the Museum, from its very inception and often thereafter. As a memorial of this for all who come here seeking knowledge about entomology, the room housing the main collection of insects is now designated The Edmund M. Walker Room. 


\title{
Work on the Orthoptera
}

\author{
F. A. URQUHART
}

The stridulation of this grasshopper [Idionotus brevipes Caudell, which is now Metrioptera sphagnorum (F. Walker)] is a soft trill of little volume, audible at a distance of but a few yards. It is sometimes continuous for some seconds, but is generally interrupted rhythmically, the divisions being produced at a rate varying according to the amount of sunshine. In bright sunshine I counted forty in fifteen seconds, the rate being thus $2 \frac{2}{3}$ divisions per second, but on an afternoon when the sun was almost wholly overcast the rate was reduced to forty-one or forty-two in thirty seconds, or about half the rate in sunshine. When close to the stridulating insect I could detect that there were no absolute pauses between the trills, a very low trilling sound filling in all the intervals. The rhythm is not always quite regular. Sometimes after a succession of trills of apparently equal length one may be shortened or lengthened, and then the regular trilling resumed.

E.M.W. (1911a)

THOSE OF US WHO HAVE STUDIED the species of insects that have been committed to the order Orthoptera are familiar with the writings of Dr. E. M. Walker, and are particularly cognizant of his accurate and detailed taxonomic studies. $\mathrm{We}^{1}$ are also impressed by his naturalist's approach to the subject, extending his interests beyond the mere specific names of the insects collected to the taxonomy of the flora of the habitat in which a particular species, or assemblage of species, was collected. In using the term "naturalist" we do so, not in its superficial connotation but rather in its more classical zoological sense as exemplified by the great naturalists of the past. These naturalists were, in the tradition of Darwin and Fabre, keen observers as well as collec-

\footnotetext{
${ }^{1}$ The plural form is used to include my colleagues in the study of Orthoptera (sens. lat.)
} 
tors; they were sensitive to slight differences in both the organisms and the environment; they studied the organism in conjunction with its environment rather than as an entity divorced from it; they utilized not only the sense of sight but also that of hearing and, indeed, smelling and feeling; and they recorded such observations in a most delightful manner in their published works. We are well aware of these sensitivities in the writings of Walker on the Orthoptera and, in his own words, we will attempt to bring out this naturalist's approach to the taxonomy and field studies of Orthoptera.

Morphological differences between isolated populations were most obvious to Walker and, as a result, he described a number of species and subspecies. But these large population variations were by no means his major concern; he was acutely aware of the finer differences within specific populations not only with respect to what might be termed by some "subspecies" or "races" and by others "sibling species" or "hybrids," but also those intangibles, term them "clines" or "population variations" or what you will, that are so bothersome to the more exacting mind of the classifier, but an intriguing problem to the research biologist. Here is an example from his publication on the Orthoptera of northern Ontario (1909a), in which he is discussing variations within a population of Melanoplus bruneri: "The Nipigon specimens exhibit great range of variation in size, coloration, winglength and in the development of the depression or notch below the apical margin of the subgenital plate in the male. This depression is not, as described by Scudder, the result of drying but is present in life, and all gradations exist between individuals in which the apical margin is entire and only a shallow depression beneath it occurs, and those in which the margin itself is as deeply or more deeply notched than in Melanoplus atlanis.",

The wide range of variation in populations of Nemobius carolinus, a characteristic of the species that has led some of us to describe new species based upon a population sample from a particular locality, was known to Walker. He discusses the north-south variations in such brachypterous species as Chloealtis conspersa, C. abdominalis, ${ }^{3}$ Melanoplus fasciatus, and $M$. extremus ${ }^{4}$ and, in conclusion, asks the vexatious question (op. cit. 1909a): "Why is the proportion of macropterous to brachypterous individuals so much greater in these northern regions than it is farther south?" His answer to this question is worth

2 [now Melanoplus sanguinipes (Fabricius)]

3 [now Neopodismopsis abdominalis (Thomas)]

4 [now Melanoplus borealis (Fieber)] 
recording in part because it gives, more than any other quotation we might use, an insight into his thinking in attempting to resolve this complex problem of population variations.

In the first place, where dimorphism in wing-length occurs the fullywinged type is of course the more primitive one, the flightless type the more recently evolved. The species is tending to become wingless, and the short-winged individuals are therefore better adapted to their environment, while the long-winged individuals are gradually becoming eliminated. Where this process has been most completely carried out only the flightless type remains, and in such cases the species may be apterous, as in Podisma glacialis, or extremely brachypterous, the wings remaining as mere vestiges, as in Melanoplus islandicus.

Now, where the environment is least favourable to the needs of the species, or where favourable conditions are localized, the elimination of the unfit will proceed more rapidly than it will under favourable conditions, so that we might, a priori, expect to find that where the trend of evolution is towards brachypterism this condition will become established most rapidly where favourable conditions of environment are localized, e.g. towards the limits of the geographical range of the species.

It will be noted that all the dimorphic species in question are boreal forms, and are more abundant and generally distributed in the north, where the long-winged forms are plentiful, than towards the southern limits of their geographical range, where this form occurs only sporadically or not at all. Hence it may be concluded that the elimination of the less fit macropterous forms at the south, where the environment is least suited to the species, has been more complete than in the north, where the conditions are more favourable.

There is possibly another factor entering into this question. It is well known that differences in wing-length are correlated with differences in habitat, and that the habitat of a given species may vary somewhat in different parts of its geographical range. Morse has pointed out that, generally speaking, species inhabiting thickets, edges of woods, etc., are flightless, and either brachypterous or apterous, while those frequenting open places, such as fields, deserts, or exposed rocky surfaces are macropterous, and capable of more or less sustained flight. The dimorphic species in question are restricted in the south to thicket habitats, but in the north, where they are more generally distributed, they occur also, to a greater or less extent, on campestral stations. Hence the macropterous type may be here preserved in adaptation to the campestral habitat.

To what extent this campestral habit actually exists and whether it is a real factor in preserving the macropterous type in these species we are not in a position to say. We have not enough knowledge of the ecology of these species in the north to make any positive statements on the subject.

The Orthoptera, unlike the Odonata to which Walker later applied himself, can be identified by the sounds that some of the species pro- 


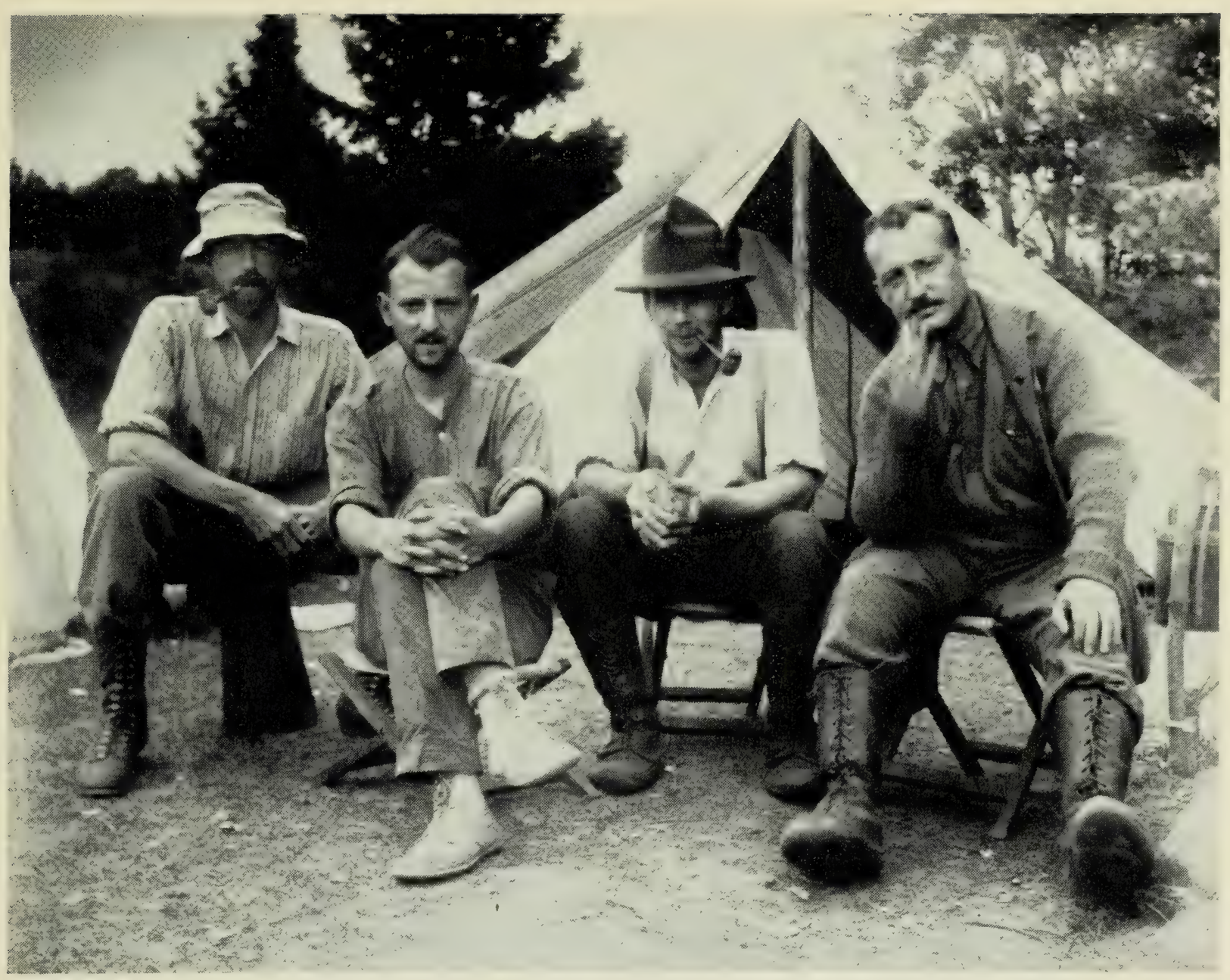

FIGURE 6. Members of the first joint field expedition of the Royal Ontario Museum of Zoology at Port Sydney, Muskoka District, Ontario, 1919: (left to right) E. M. Walker, L. L. Snyder, E. B. S. Logier, N. K. Bigelow. 

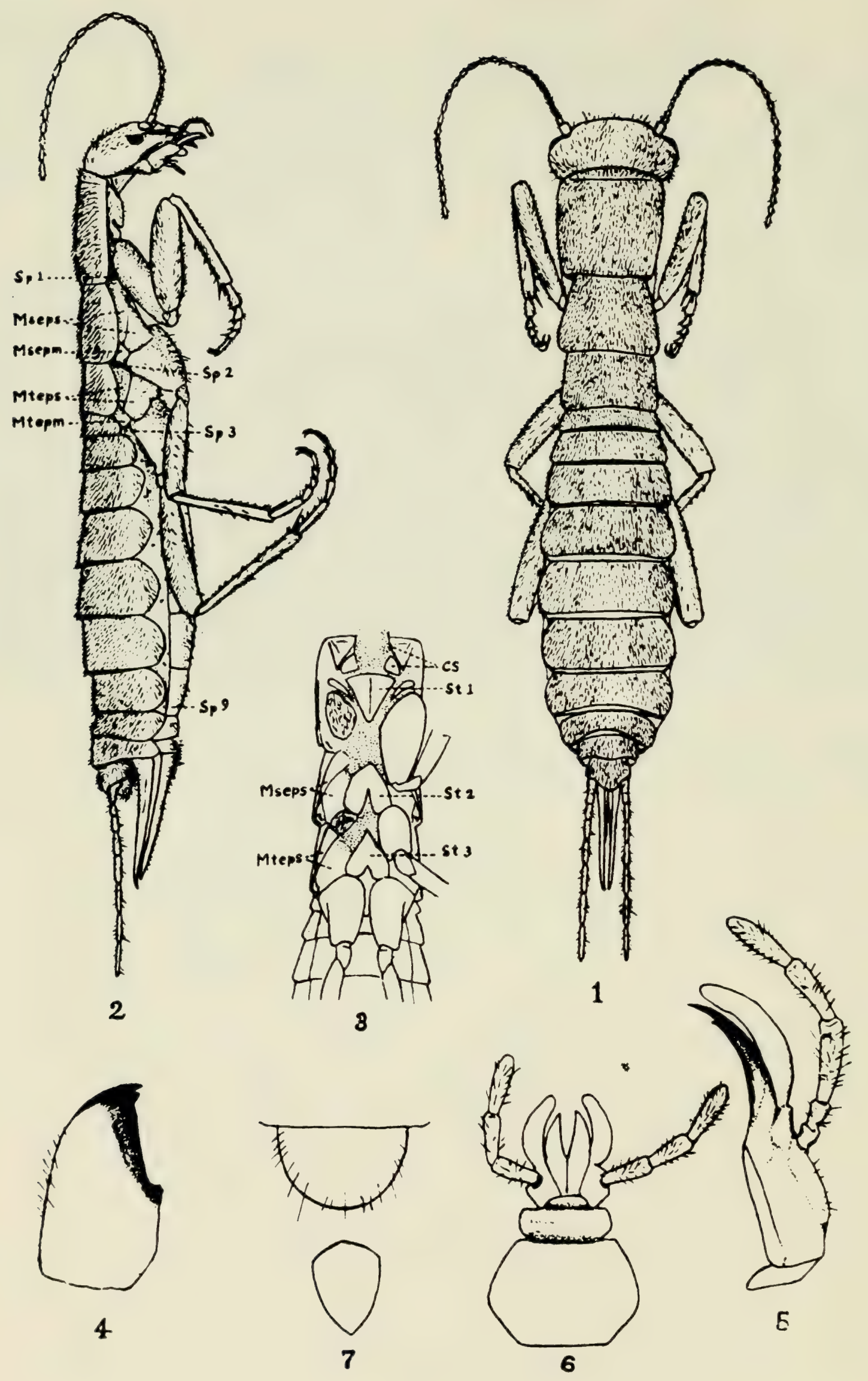

GRYLLOBLATTA CAMPODEIFORMIS, n. gen tit. Si.

FIGURE 7. Plate from Dr. Walker's first paper on Grylloblatta campodeiformis (1914a). 
duce. Those of us who have collected Orthoptera are well aware of the importance of sound not only as a means of identifying certain species, sight unseen, but also of leading the collector to new records and, in some instances, to species new to science. A good example is found in Walker's description of the discovery of Gryllulus domesticus $^{5}$ in Toronto (1904a): "Late in the fall of 1903 I heard the chirp of a cricket in the basement of the Toronto General Hospital, but paid little heed to it, thinking it was that of a common field cricket which had entered the building. My attention was again drawn to the sound, however, as it persisted night after night, and I began to notice that it was higher pitched and of less volume than that of the field cricket. I traced the sound to the boiler-room and found, as I had expected, the European house cricket, which I had never before met with in this country. They were there in plenty, lurking in the chinks between the bricks of the wall, and positively swarmed under some loose bricks close to the furnace. They were found in all stages, most of them nearly matured. Imagoes continued to be found throughout the winter, but became scarcer in early spring, and by May had nearly disappeared."

It would appear that Walker, as a young intern, was more interested in the crickets in the furnace room than the patients in the emergency room of the hospital.

Sound was also a taxonomic character which he considered important and, as we now realize through the research of Alexander, Fulton, and others, modern techniques have made sound spectra of much importance in subspecific and interspecific analyses. Of the many references made in Walker's work to the sounds produced by species of Orthoptera, which he could imitate most accurately to the amusement and enlightenment of his students, we have chosen the following taken from his discussion of the Orthoptera of northern Ontario (1909a) :

Another feature of interest in the fauna of Fort William and Nipigon is the total absence of Gryllidae. Low, grassy, partly wooded pastures on the Nipigon River, in every way resembling the favourite haunts in the more southern parts of Ontario of Nemobius fasciatus and $N$. carolinus, were searched for these crickets in vain; nor could the chirping of any Gryllid be heard either by day or night. In fact, the only Orthopterous sound which was heard at night in this district was the occasional "zeep, zeep, zeep, zeep" of the northern katydid (Scudderia pistillata). During the day, 
however, the chorus of Orthoptera rivals that of more southern latitudes in the volume of sound produced, though considerably different in quality. Instead of the chirp of Gryllus and the low undertones of Nemobius, and the familiar "ze-e-e----jip, jip, jip" of Orchelimum vulgare, we hear on every side the loud, but not especially harsh, "shklip, shklip, shklip, shklip" of Mecostethus gracilis, the lower-toned but more rapid and harsher "z-z-z-t, z-z-z-t" of Chloealtis abdominalis, and the similar, but more subdued, notes of its congener, $C$. conspersa, varied by the still softer tones of Stenobothrus curtipennis. ${ }^{6}$ An occasional "tsip!" the day note of Scuderia pistillata, and the feeble little trill of Xiphidium fasciatum, which is only audible at close range, complete the orchestra of this northern region, except in the open bare rocky or sandy places, where Circotettix verruculatus keeps up its incessant clatter, and in the open grassy plains at Fort William, where a newer and unfamiliar note was heard, leading to the discovery of the Dectician Idionotus brevipes. ${ }^{7}$ This note is a continuous and monotonous trill, resembling that of Orchelimum vulgare with the "jips" omitted.

In classical naturalist form, Walker described the country in which he was collecting in a delightful manner. His description of the Fort William area contains a few elements of the travelogue as well (op. cit. 1909a):

At Fort William the collecting was all done on the west side of the Kaministiquia River. We crossed the river in a skiff and followed a road about a mile and a half over a stretch of level country to the foot of Mt. McKay. This flat area is open and prairie-like for a distance of several hundred yards west of the river, beyond which it is a dense spruce swamp, broken only by the clearings of an Indian village which are scattered along each side of the roadway. At the foot of Mt. McKay we left the road and followed a footpath up the mountain. Mt. McKay is a bold basaltic cliff rising suddenly out of the level spruce swamp around it to a height of about 1,000 feet, its sides very steep, and in many places quite perpendicular. The summit is about 1,600 feet above sea level.

Following the path up a steep slope wooded with a mixed growth of small spruce, canoe birch, aspen and a few scattered white pine, we reached, when about half way to the summit, a small treeless plateau, some seventy-five square yards in area, and covered with short grass and small herbaceous plants. This proved an interesting spot for Orthoptera....

Above the plateau the sides of the mountain are for the most part almost vertical, but we followed a level pathway for some distance through the woods, and then completed the ascent by scrambling over the slabs of a talus slope, finding ourselves at the summit in a scrubby wood of Banksian pine, poplar, birch, etc. with small scattered openings, which yielded good results in Orthoptera.

${ }^{6}$ [now Chorthippus curtipennis (Harris)]

7 [now Metrioptera sphagnorum (F. Walker)] 
Walker was an avid collector. In his records on the Orthoptera of the Canadian Northwest (1906c), he states that only a few minutes to half an hour were spent at the various railway stops. Nevertheless, he was able to report on the occurrence of forty-nine species as well as to include certain field observations, e.g. concerning Circotettix lobatus: "It makes a very loud but less harsh sound than $C$. suffusus and verruculatus."

To those of us of recent vintage, such names as Criddle, Blatchley, and Scudder are legendary. These men were Walker's colleagues with whom he shared his specimens and his observations and to whom he submitted doubtful identifications for their authoritative conclusions. Among such outstanding orthopterists was also J. A. G. Rehn of the Academy of Natural Sciences in Philadelphia to whom we owe so very much for his monumental contributions to this subject. These orthopterists had a profound influence on the collection and presentation of results by Walker.

In his publication dealing with the Acrididae of Ontario (1899), Walker reports finding Podisma variegata at DeGrassi Point on Lake Simcoe: "It can be at once distinguished from all our other Acridiidae, except its ally $P$. glacialis, Scudd., by its having no trace of either tegmina or wings. The latter species, which is not uncommon in the White Mountains, N.H., has been taken at Sudbury, Ontario, by Dr. Scudder, but is not found with us at the south, being, like most of the genus, a species which affects high altitudes or latitudes."

Dr. Walker's interest in this bizarre, wingless genus Podisma was aroused as a result of obtaining a number of specimens in Algonquin Park, Ont. After studying other specimens from various localities in the eastern United States, loaned to him by J. A. G. Rehn, Walker concluded (1903c): "A careful study of all these specimens has revealed a complete series of gradations from the typical glacialis of the White Mountains to the typical variegata from Pennsylvania, though these extremes are widely different, not only in structure and markings, but in habits and character of environment." His analyses and illustrations of these variations, including the characterization of a new subspecies $P$. glacialis canadensis, were remarkably thorough for a paper published in 1903. In attempting to account for the variations, he considers a number of observations concerning behaviour and habitat, and then he goes on to say:

From these various facts it may be inferred that $P$. glacialis is the more primitive form, especially as the genus is typically an alpine one, and that 
it once inhabited a much larger area, but after the retreat of the ice-sheet it disappeared from this area, except in the northern part and on the mountains farther south. Variegata, on the other hand, may be regarded as an incipient species, the product of an effort on the part of the parent species to survive amid the altered conditions of its environment. These conditions, as we go southward, diverge more and more from those to which the insect was originally adapted and hence it is not surprising to find slight modifications of structure and colour-pattern corresponding in degree with these changes.

Its occurrence in swampy stations southward is what would be expected from the fact that wet soil is a poor conductor of heat, and such places are cooler than the more open, dry country, but its fondness for hemlock in Pennsylvania seems to indicate a distinct specialization in the insect's habits in this locality. Further observation, however, is desirable on this point.

The recent study of these grasshoppers by Rehn and Randell ${ }^{8}$ has brought, however, much new information to bear on the systematics of this group, and altered considerably the views concerning it. As has so often happened in entomology during the past fifty years, study of the internal genitalia has provided new evidence, in this case requiring the assignment of the North American species to the new genus Boonacris, and confirming the specific status of $B$. variegata. The subspecies Boonacris glacialis canadensis (E. M. Walker) is shown to extend from central Ontario, west to Wisconsin and Minnesota.

In reading the publications on Orthoptera by Walker, one is amused by the homely field notes and interesting, but pertinent, remarks that not only add colour to the description presented but which tend to make the reader feel that he is taking part in the activities of the author-a descriptive form of presentation lacking in most modern writings. For example, in writing about Melanoplus atlanis when he was collecting at Nipigon (1909a): "As it was raining heavily when these specimens were captured, only a few minutes were spent here and nothing else was taken." In a few words an experience common to both author and reader is shared, and a common bond established. In his account of the cockroaches recorded from Ontario, Dr. Walker felt obligated to list all the records he had accumulated, and for Panchlora acolhua he wrote (1912d): "Some years ago I sent a Panchlora for determination to Mr. A. N. Caudell, who labelled it somewhat doubtfully $P$. acolhua Sauss. \& Zehntn. The specimen has since

8[Rehn, J. A. G. and R. L. Randell. 1962. Boonacris, a new generic component of the North American Melanoplini (Orthoptera: Acrididae: Cyrtacanthacridinae). Trans. Amer. Ent. Soc. 88 (2, 3): 105-182.] 
been destroyed by dermestids so that the determination cannot be verified. It was taken at Toronto from a bunch of bananas."

Although little of a systematic and faunal nature was published on Orthoptera by Dr. Walker after 1912, his interest in the group did not diminish. It was, in fact, largely this continuing interest and familiarity with Orthoptera which enabled him to make most of the observations for his paper (1957b) on changes in the insect fauna of Ontario. These observations, continued annually over a period of some sixty years, gave him the unusual opportunity of documenting for southcentral Ontario a gradual withdrawal of certain species of insects, chiefly grasshoppers, to more northerly latitudes, and their replacement by others which had originally a more southerly distribution.

Those of us who have studied Orthoptera are indeed grateful to Walker for his contributions to this group. My colleagues would, I am certain, join with me in honouring our first Ontario orthopterist. A few of us have had the pleasure of knowing Walker as a professor, as a colleague, or as a friend. Although our paths of research may have strayed from that of the classical naturalist, into the laboratory where controlled experiments have replaced the net and killing bottle, we nevertheless look back with pleasure, and still read with considerable enjoyment, the writings of these early naturalists and field biologists who laid the foundation for ecological research in the future. 


\title{
Grylloblatta
}

\author{
H. H. J. NESBITT
}

While collecting on Sulphur Mountain, Banff, Alberta, on June 29th, 1913, Mr. T. B. Kurata and the writer captured two specimens of a peculiar wingless thysanuriform insect, which at once struck me as very remarkable on account of their possessing an ovipositor like that of the Tettigonidae (Locustidae). The two specimens, both females, are of about the same size, and, judging by the size and appearance of the ovipositor, are probably mature. They were found running about like centipedes under the stones of a talus-slope at an altitude of about 6500 feet. Considerable search was made for more specimens, but without success.

A study of these specimens shows that they are genuine Orthoptera, but of a very generalized type and cannot be placed in any of the known families of this order. Their appearance is somewhat suggestive of the termites, or, still more, of the nymphs of the Plecoptera, but that they are true Orthoptera is at once apparent, in spite of the total absence of wings, on an examination of the mouth-parts, the cervical and thoracic sclerites and the ovipositor.

This insect forms the type species of a new genus, Grylloblatta, and a new family, Grylloblattidae.

E.M.W. (1914a)

WHEN E. M. WALKER delivered his presidential address to Section V of the Royal Society of Canada in 1937, he entitled it "Grylloblatta, A Living Fossil," indicating thereby that he thought that he was dealing with an animal that had survived beyond its era. The term "living fossil" was first used by Darwin when discussing the Ginkgo and has subsequently been applied to such familiar zoological oddities as Limulus, Sphenodon, and the coelacanth Latimeria, to name only three members of no mean host. Interest in "living fossils" or "relict 
species," as they are sometimes called, arises from the phylogenetic information they provide about the internal anatomy, physiology, and behaviour of lines of organisms long extinct. Secondly, there may be the subconscious desire on the part of most taxonomists, possibly an atavistic hangover from our association with the alchemists, to find some new and totally different form that will at once establish, beyond any reasonable doubt, the relationships between living and extinct forms. But, for a taxonomist to take proper advantage of such information as he may stumble upon, he must be properly prepared to recognize these new forms for what they really are. Had Dr. Walker not had the innate ability and the natural inclination that is apparent from his autobiography, and had he not been trained as a careful observer with an eye for recognizing possible relationships, his discovery in 1914 of "a peculiar wingless thysanuriform insect" would not have led to his recognition that he had here a primitive orthopteroid insect that would shed light on the phylogenetic relationships within this complex of insects. As Pasteur has said, "Chance favours the prepared mind." And just how appropriate this aphorism really is may be seen from the fact that although Grylloblatta had actually been collected as early as 1906 (Gurney, 1948), ${ }^{1}$ its true significance was not appreciated until Walker's independent discovery.

What then did Walker do and why is his work so significant? In the first place, following the example of Darwin, he presented a vast body of information in a series of beautifully illustrated papers (vide bibliography 1931b, 1933c, 1938b, and 1943b) on the anatomy of Grylloblatta, in which he discussed in great detail the exoskeleton and the musculature of the head, the thorax, and the abdomen, and lastly the organs of digestion (1949). In two separate papers (1919b and $1922 \mathrm{~b}$ ), he compared the terminal abdominal structures of the female and male with the similar structures of orthopteroid insects. Space does not permit me to describe these papers; they speak for themselves, and any attempt on my part to rephrase them would be most presumptuous.

Secondly, from his vast knowledge of the orthopteroid groups, Walker was able to assess the phylogenetic significance of Grylloblatta and to show that it approaches more closely the requirements of the ancestral Orthopteron than any other living or fossil form. The

${ }^{1}$ Gurney, A. B. 1948. The taxonomy and distribution of the Grylloblattidae (Orthoptera). Proc. Ent. Soc. Wash. 50(4) : 86-102. 
affinities of this group have provoked much lively discussion. Crampton, in a series of papers, advanced the view that Grylloblatta represents a family of the Orthoptera (sensu stricto) most closely related to the Stenopelmatidae in the Tettigonioidea. This view is outlined in his later papers of $1927^{2}$ and $1933,{ }^{3}$ and again most emphatically in $1935 .^{4}$ The late Dr. F. E. Zeuner of the British Museum, on the basis of his studies on the fossil Ensifera, concluded $(1939)^{5}$ that "the Protoblattoidea and Protorthoptera are closely allied to each other. ... This enables one to select some features which the primitive ancestral Orthoptera in their widest sense must have had in common: a more or less prognathous head, a body rather depressed than round, a pronotum without vertical lateral lobes, gressorial legs with 5 tarsal segments, forewings with an almost palaeodictyopterous venation, hind-wings with extended and foldable anal area, and long, segmented cerci. Strangely enough there is one living form which exhibits clearly most of these requirements of an ancestral Orthopteron in its widest sense. This is Grylloblatta campodeiformis Walker (1914). Since it has a number of features which are more characteristic of the true Orthoptera, it might rightly be called a living, though specialised, representative of the ancient Protorthoptera."

Finally, Giles, in $1963,{ }^{6}$ expressed much the same idea in his study of the phylogenetic position of the Dermaptera when he stated: "The Grylloblattodea represented the recent survivors of a group near the base of the orthopteroid complex," a view not too divergent from that expressed by Richards and Davies in $1957^{7}$ when, in re-writing Imms' great work in entomology, they gave ordinal status to the Grylloblattodea, stating, "probably the Grylloblattodea are to be regarded as the only living remnants of a primitive stock from which both Blattoids and Orthoptera evolved."

${ }^{2}$ Crampton, G. C. 1927. The abdominal structures of the orthopteroid family Grylloblattidae and the relationships of the group. Pan-Pacific Ent. 3(3): 115-135.

${ }^{3}$ Crampton, G. C. 1933. The affinities of the archaic orthopteroid family Grylloblattidae, and its position in the general phylogenetic scheme. Jour. N.Y. Ent. Soc. 41: 127-166.

${ }^{4}$ Crampton, G. C. 1935. A defence of the view that the grylloblattids are descended from the Protorthoptera and lead to the tettigonioid family Stenopelmatidae-a reply to Dr. E. M. Walker. Jour. N.Y. Ent. Soc. 43: 97-111.

5 Zeuner, F. E. 1939. Fossil Orthoptera Ensifera. London. Brit. Mus. (Nat. Hist.), $321 \mathrm{pp}$.

${ }^{6}$ Giles, E. T. 1963. The comparative external morphology and affinities of the Dermaptera. Trans. Roy. Ent. Soc. Lond. 115(4): 95-164.

'Richards, O. W. and R. G. Davies. 1957. Imms' General Textbook of Entomology. Methuen and Company Ltd. Pp. 886. 
But, in all fairness, we should let Walker state his own position, as he did in 1933:

In its head and appendages Grylloblatta is nearest the Saltatorial Orthoptera, though possessing a more primitive form of head capsule. As far as these parts are concerned Grylloblatta almost exactly fits the hypothetical concept of a common ancestor for the Saltatoria and the Dermaptera. It is only in the hypopharynx and mandibles, and of course the reduction of the compound eyes and lack of ocelli that any essential differences need be assumed in the ancestral form. The hypopharynx of Grylloblatta is doubtless somewhat degenerate. The presence of superlinguae in the Dermaptera, if the lateral lobes are to be interpreted as such, is a primitive feature, retained in this order only, among the groups here considered. It is, however, by no means certain that these lobes are true superlinguae. The lack of molar processes on the mandibles of Grylloblatta is also a modification of the primitive condition, since these processes are rarely absent in the orthopteroid groups.

\section{And later in 1943:}

The present study of the abdominal exoskeleton and musculature of Grylloblatta has not materially altered the views long held by the writer concerning its phylogenetic relationship. There seems to be no reason to doubt that its nearest affinities are with the most primitive representatives of the suborder Ensifera, as stated by Crampton (1927). We are not prepared, however, to include the Grylloblattidae in the same suborder as the Ensifera, as proposed by Crampton (l.c.) and, doubtless independently, by Handlirsch (according to Ander, 1939), and Weber (1933). According to this view the Caelifera, which include the remaining families of Saltatoria, are more widely separated from the Tettigonioidea and Grylloidea than are the Grylloblattidae, a point of view that ignores the many important differences which exist between the Grylloblattidae and the Saltatoria as a whole, e.g., the very different type of phallus and the persistence of many primitive characters that are not found in any of the Saltatoria. Admitting that the Ensifera and Caelifera are widely separated and that the former "as a separate stock can be traced as far back as the Upper Carboniferous" (Zeuner, 1939), we concur with Ander's view that the Grylloblattidae should be treated as a group apart from the Saltatoria. Whether it should be given ordinal rank, however, is largely a matter of convenience and will not be discussed at the present stage of our investigation.

As to Grylloblatta's relationships with the other orthopteroid orders, little need be said at present. It shows little resemblance to the Phasmaria in the abdominal musculature, although sufficient similarity exists in the external features of the terminal segments (Walker, 1919, 1922; Snodgrass, 1937) to warrant a fairly close association with this group. The blattoid complex is also definitely farther removed from Grylloblatta than are the Saltatoria. There is the similarity in the phallus and the retention 
in both groups of such primitive characters as the segmented cerci and the broad continuous layers of the inner dorsal and ventral muscles, but the special features of the blattoid groups, such as those of the lateral muscles and the genital segments, are quite different from the corresponding parts in Grylloblatta and indicate a different line of descent.

When we turn to the internal anatomy, much the same picture is unfolding, despite the fact that only the organs of digestion and the musculature and nervous systems have been dissected in any great detail. As a result of his work on the alimentary canal, Walker was able to conclude in 1949 that: "(1) Grylloblatta shows definite evidence of closer relationship to the suborder Ensifera of the order Saltatoria than with any other orthopteroid group. (2) While Grylloblatta resembles the Ensifera in most of the gross features of its digestive organs it differs strikingly in the inner structure of the proventriculus. (3) The differences in the proventriculus, together with those already described in other parts of the body are sufficient to warrant its classification in a group apart from the Ensifera, and even from the Saltatoria. (4) The common ancestry of the Ensifera and Caelifera is more remote than that of the Ensifera and Grylloblattaria."

Somewhat later, Nesbitt (1958), ${ }^{8}$ reporting on preliminary studies on the nervous system, was able to state that "Grylloblatta differs so markedly from any known family of Ensifera that it warrants at least subordinal rank. The findings which I have reported above in the main substantiate this view. The brain itself is similar to that of Ceuthophilus but the stomatogastric system and the primitive arrangement of the nerves of the thoracic and abdominal ganglia are sufficiently different from those of the known Ensifera, if not unique, to raise doubts about the close relationship of this insect to any of the other described forms." Later studies of the brain itself show that as the eyes are greatly reduced the optic tracts are very similar to those of Termopsis and the development of the corpora pedunculata is, if anything, more primitive than that of the Isoptera. Strangely enough the centres associated with the sensory root of the antennary nerves are not correspondingly as large as they are in Termopsis.

Turning from strictly anatomical studies, one of the most difficult things to understand about the biology and zoogeography of these bizarre creatures is how a form that is largely confined to cold, damp

8 Nesbitt, H. H. J. 1956 (1958). Contributions to the anatomy of Gryllablatta campodeiformis Walker. 6. The Nervous System. Proc. Tenth Int. Cong. Entom. 1: 525-529. 
habitats at high elevations could be the relict of a group of insects that arose in the Pennsylvanian or Permian period, when the climate of North America and Western Europe was hot and damp in the former, and dry to the point of forming evaporites in the latter. Grylloblatta has now been taken at many localities in western North America and several other species are known. Also known are the closely related genera Galloisiana in Japan, and Grylloblattina in Siberia (Gurney $1948 ; 1953^{\circ}$ ). The microclimates of all the ecological niches are essentially similar, except that that of one Japanese species, as reported by Silvestri, is somewhat more moderate, with the result that this latter form is capable of more rapid movements. Observations by Campbell (1949) ${ }^{10}$ also suggest that some of the North American Grylloblatta can exist at lower elevations and under much lower humidity than had been generally believed possible. This unusual and restricted distribution would indicate that we are here dealing with the survivors of a once widespread but now nearly extinct group that has adopted the present inimical niches and has been able to survive there because of reduced predation. How then can we explain the descent of these present-day cold-living insects from forms that arose in the Carboniferous or the Permian?

At least two explanations come to mind. One theory would suggest that these insects, very early in their evolutionary career, underwent mutational changes which allowed them to become associated with the ice sheets that King (1961) $)^{11}$ maintains once covered certain areas of the ancient continent of Gondwana, and that they have subsequently remained in association with similar climatic zones, which fact might account for their low rate of metabolism and for the fact that they have shown so little evolutionary change over this long period. Kamp (1963) ${ }^{12}$ has shown a close correlation between areas formerly glaciated and the distribution of the North American species of Grylloblatta. A second explanation is that these insects, along with

\footnotetext{
${ }^{9}$ Gurney, A. B. 1948. op. cit. note 1. 1953. Recent advances in the taxonomy and distribution of Grylloblatta (Orthoptera: Grylloblattidae). Jour. Wash. Acad. Sci. 43(10): 325-332.

${ }^{10}$ Campbell, M. G. 1949. Notes on Grylloblatta at Kamloops. Proc. Ent. Soc. B.C. (1948). 45: 1-5.

${ }^{11}$ King, L. C. 1961. XIII, The Palaeoclimatology of Gondwanaland during the Palaeozoic and Mesozoic Eras, IN A. E. M. Nairn's, Descriptive Paleoclimatology. Interscience Publishers Incorporated, N.Y.

12Kamp, J. W. 1963. Descriptions of two new species of Grylloblattidae and of the adult of Grylloblatta barberi, with an interpretation of their geographical distribution. Ann. Ent. Soc. Amer. 56(1): 53-68.
} 
other protorthopteroid and primitive insects, arose in the late Carboniferous and were the inhabitants of lush semi-tropical areas similar to those that are now inhabited by cockroaches and other soft-bodied Orthopterons. As the following Permian period was dry, and as evolutionary pressure would favour those mutations which led to a sclerotized integument which would allow life in semi-arid zones, it would be necessary to presume that the grylloblattoid stock was able either to adjust itself to these conditions or to remain in tiny pockets where the relative humidity would remain fairly high, and where the insects could remain virtually unchanged; what is essentially an arresting of evolutionary change. As can be seen, this explanation is fraught with countless difficulties and, if accepted, necessitates the finding of some method of explaining when such profound mutational changes arose that would account for their present physiological needs. It is possible that further geological work will show their remains in other parts of North America and we may subsequently see that they advanced and retreated with the various advances of the ice sheets.

As a postscript, this student would like to add that, shortly after he began his graduate work with Dr. Walker, he first made the acquaintance of the "ice bug" and was told by Dr. Walker how he and Mr. Kurata came upon this insect, how excited they were at the time, how later the male was found, how precious the first few original specimens were to insect phylogenists, and how later Dr. Norma Ford (now Mrs. Walker) was able to supplement the meagre supply of specimens in the Department of Zoology. These were the insects that the graduate students of entomology came to know and these were the experimental subjects for Walker's work on the morphology and phylogeny of this unique insect. In trying to remember those days, this student recalls with what pleasure he looked forward to the laboratory sessions in entomology, which were profusely illustrated with sketches and by the teacher's ability to mimic the behaviour of insects, in particular, the praying mantis, with its bizarre expression and its unusual ability to transfix its prey with those neck muscles which enabled it to move the head in the "no" motion. These practical periods were also enlightening to this student, who had come from a university which was notable for its characters, because Dr. Walker would on occasion enhance his laboratory talks with accounts of the more unusual and eccentric entomologists he had known, and with excerpts from Lewis Carroll and his delightful friends of the world beyond the looking glass. 


\section{ADDENDUM}

Editor's note: Some of the background leading up to this discovery was included by Dr. Walker in a talk to the Biology Club of the University of Toronto on March 17, 1948.

Nineteen-thirteen was a banner year for me in more ways than one. I was teaching invertebrate zoology but with very little first hand knowledge of marine forms. The Department was in need of material and so was the new Royal Ontario Museum, which was to be opened in 1914. Mr. Kurata of the present museum staff and I had become close friends and decided to go west that summer, stopping at several localities en route, our final destination being the Pacific Biological Station. We wanted to collect marine material at the Station and I was on the lookout for dragonflies wherever I went.

We stayed over at Banff, where I had been with the British Association in 1897. We didn't realize that there might be other hotels there besides the great C.P.R. one. So when we were met at the station platform by a long row of buses, with the drivers all yelling at us, we hardly knew which way to turn. We walked the whole length of the platform and finding, at the far end, a small unlighted bus, with neither driver nor passengers, we got in. Soon the driver appeared and a few other passengers, and we started to climb the long trail up Sulphur Mountain. I remember how desperately cold we were, but we finally landed at the Upper Hot Springs Hotel, which at that time proved to be the one perfect place for us. There were hot springs close at hand but, most important of all, it was halfway up the mountain and when we wanted to collect on the mountain top we had only half way to go, and the same was true if we wished to explore the valley.

On one of our trips to the top of Sulphur Mountain, when about 6500 feet above sea-level, Kurata called to me to see an insect he had found under a stone.... I knew at once that this creature was something newunlike anything ever found before. Soon we had another. Both were adult females and both had ovipositors like those of the long-horned grasshoppers. But they ran like cockroaches and had the general shape of earwigs or stonefly nymphs. I knew that this was a real discovery yet I could hardly believe it." 


\section{The Study of Odonata}

\section{PHILIP S. CORBET}

Just after leaving the marsh, I was attracted by a clear-winged dragonfly, evidently a Corduliine, speeding along a few feet above the water and closely following the shore-line. I took up a position in the shelter of a bush and waited for a chance to strike with the net from behind. In a few minutes I had netted a male of Cordulia shurtleffi Scudd., and soon afterwards I had several more. This is a beautiful insect with a bronze-green body and brilliant green eyes....

E.M.W. (1916c)

CANADA IS A COUNTRY of particular interest to students of the Odonata. It is the headquarters of two large Holarctic genera-Aeshna and Somatochlora; it includes the highest latitudes at which dragonflies can exist in the New World; and within its boundaries many species, commoner and better known in the United States, reach the northernmost limits of their distribution.

Sixty years ago, when Edmund Walker published his first paper on dragonflies, very little was known about the Canadian species. Such information as existed was scattered and mainly in the form of short lists of determinations, often published by specialists from Europe or the United States. Although most of the Canadian species had been described, virtually nothing was known of their distribution and habits; and two of the most important genera urgently needed revision.

Now the third and final volume of Professor Walker's book, The Odonata of Canada and Alaska, is almost completed. This, with the two volumes already published $(1953,1958)$, will give the first detailed and definitive account of the Canadian Odonata. Despite the great area this monograph has to encompass, it will be one of the 
most informative and beautiful of its kind, and will leave students of Canadian dragonflies as well equipped as any to study this rich fauna of nearly 200 species. To trace the steps by which this remarkable change was effected is to survey Walker's contributions to the study of Odonata.

From the first, his aim has been to establish a reliable foundation of systematics on which could be built the synthetic studies of phylogeny, zoogeography, and ecology. In pursuing this aim, he adopted the then unusual practice of including larvae as subjects for detailed taxonomic study. This policy was especially appropriate to the problems faced by entomologists in Canada in the early years of this century, because collections in sparsely populated areas often had to be made during short or impromptu visits, when not all the local species were in the adult stage. Accordingly his ability to recognize larvae allowed Walker to extract far more information from small collections than would have been possible had he restricted his studies to adults. His first records of Odonata from Prince Edward Island, for example, list sixteen species (1917b), six of which were collected only as larvae. Another, and perhaps more important, consequence of this policy, is that his biological studies take cognizance of both larval and adult ecology. This imparts to his work a wholeness of approach which has become one of its hallmarks. It is this very quality which makes it difficult to categorize his sixty-six publications on dragonflies; but for purposes of this article these contributions may be distinguished under four heads: larval systematics, adult systematics, distribution, and general biology.

Odonata larvae are notoriously difficult to identify at the specific level, and it is small wonder that their study has been neglected. Many hours of painstaking examination yield, at best, modest rewards and sometimes none at all-as for instance, in certain Coenagrionidae (1944). In his book (1953, p. 254) Walker writes of Ischnura that "although four of the six species... have been described and a fifth is added herewith, not enough material is available for the drawing up of a satisfactory key." Also, larval characters that appear to be generic do not always correspond to those based on adult features, a situation Walker encountered in Enallagma, Coenagrion, and Ischnura (1953, p. 120). Such differences as exist are often those of proportion or microstructure, and so necessitate illustrations of high calibre, and a critical evaluation of the available material. In Walker's descriptions of larvae these requirements are always met, and emphasis is 
laid on the practical: of the twenty-two publications containing larval descriptions, nearly all include workable keys to the other related North American species, or a critical appraisal of the diagnostic characters. Examples are to be found in his treatment of the North American species of Aeshna (1912f, 1921, 1934b, 1941c, 1941e), Leucorrhinia (1916e), Sympetrum (1917d), Somatochlora (1925, 1941c, 1941d), and Gomphus (Stylurus) (1928b), and of the Canadian species of Lestes (1914c, d) and Ophiogomphus (1933d). Now, of course, many of these descriptions are reproduced in his book, but the original papers still stand as models of their kind. That dealing with the Canadian species of Ophiogomphus illustrates his method. Pointing out that the uniformity of their larval habitat (all are shallow burrowers in clear, sandy streams) is consistent with their homogeneity of form, Walker remarks that the morphological characters so far noticed in species of Ophiogomphus are not sufficiently incisive to be useful. After correcting the terminology applied to odonate anal appendages, he describes the larva of $O$. anomalus, thus making this stage known for all of the eight Canadian species. The key to these which follows makes use of novel and subtle characters (such as the proportional lengths of cerci and paraprocts, and the shape of the third antennal segment) which are meticulously illustrated in accompanying figures. The paper concludes with a detailed description of each of the eight species, stress again being laid on diagnostic characters. Larvae of some genera (e.g. Enallagma, Cordulegaster) are first distinguished or described by Walker in his book, in which he has made it a point to include keys to all the known species. His recognition and illustration of selected characters in these two genera (Enallagma: 1953, pp. 188-206; Cordulegaster: 1958, pp. 294-300) are especially noteworthy. Since the publication (1904c) of his first paper on a dragonfly (an account of the larva of Gomphus furcifer), Walker has been responsible for first descriptions of larvae of considerably more than fifty species of North American Odonata, and by his keys has enabled a much larger number to be reliably determined.

His detailed knowledge of larval taxonomy made it possible for Walker to recognize exuviae in situ, and thus to identify and characterize the breeding sites of several species, including elusive northern forms such as Aeshna sitchensis (1921) and A. subarctica (1934b). When recording larvae that he himself has collected, he often uses their size-distribution to infer the duration of larval life in nature.

These first descriptions of larvae, referred to above, were neces- 

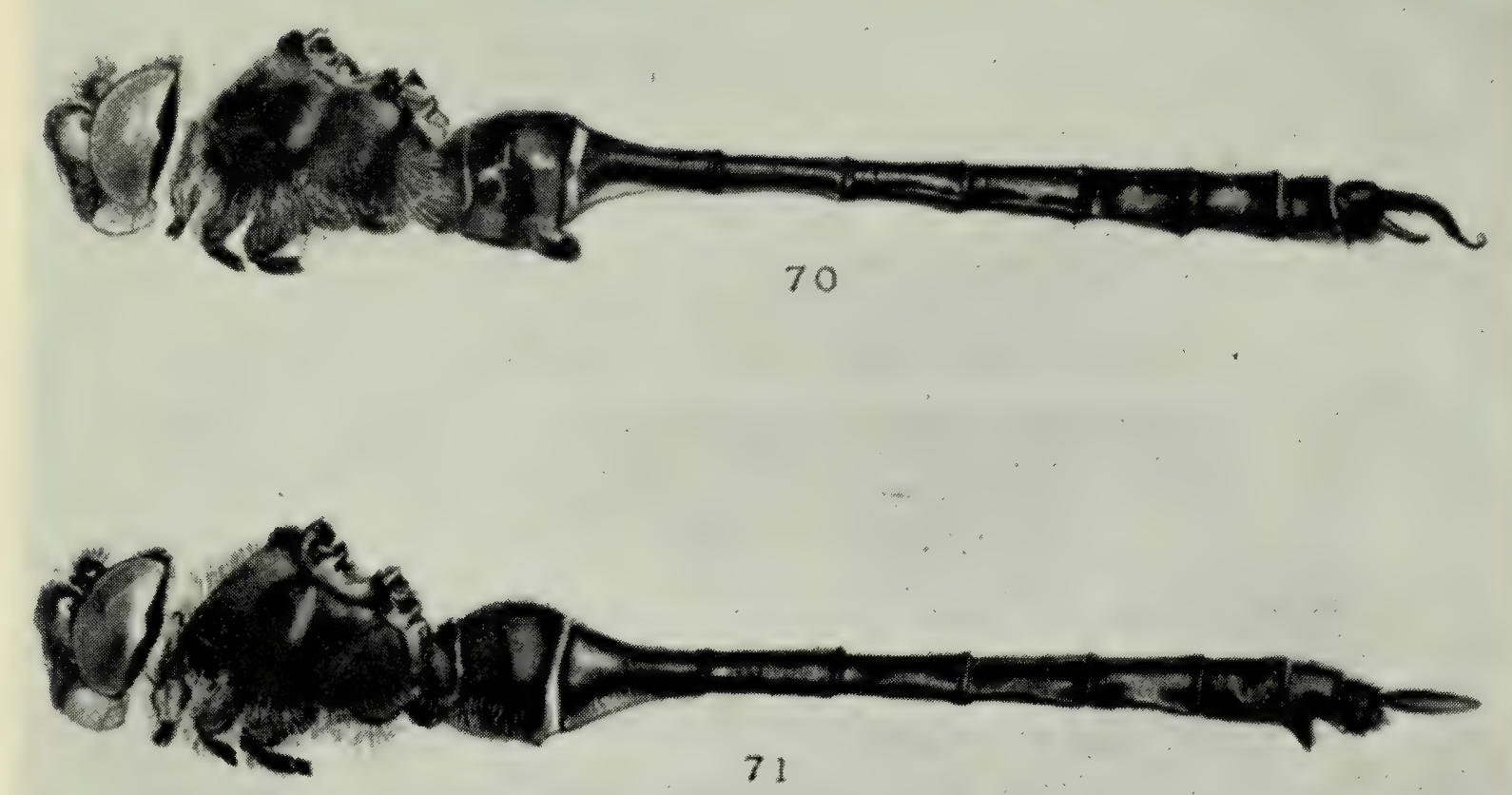

FIGURE 8. Wash drawings by Edmund Walker of Somatochlora whitehousei Walker from his monograph of the North American species of Somatochlora (1925). 


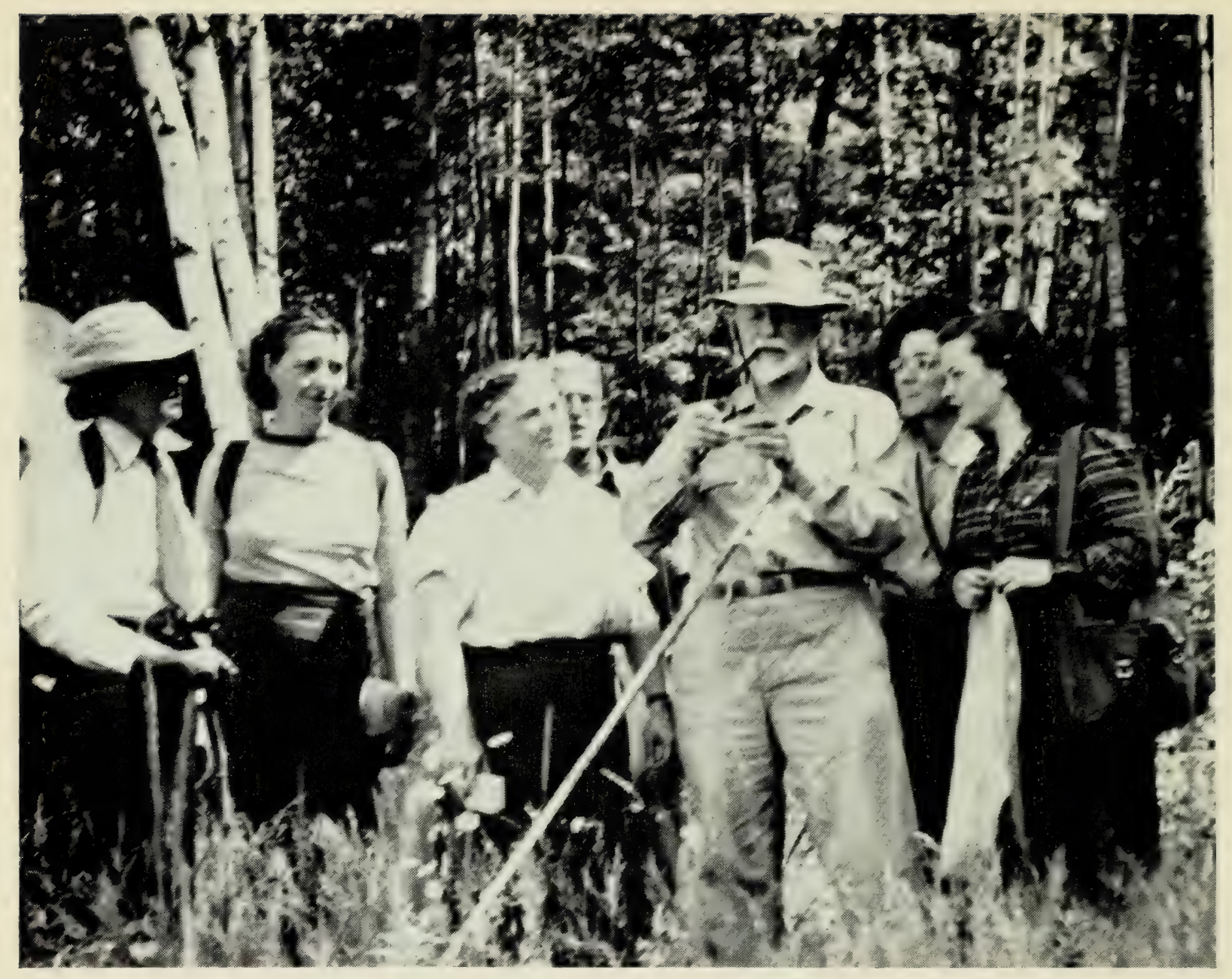

FIGURE 9. Edmund Walker in the field with a group of naturalists, Federation of Ontario Naturalists Summer Nature Camp, 1946, Buckshot Lake, Ontario. 
sarily restricted to the final instar, the stage most likely to feature in collections. But when opportunity offered, Walker made interesting excursions into the field of ontogeny. In his Aeshna monograph (1912f) he describes the last eight larval instars, and correctly predicts the total number as twelve or thirteen; and in a later faunistic study (1924) he describes the juvenile colouration and a remarkable structural dimorphism which he encountered in young larvae of Aeshna interrupta. His description (1925) of the first seven larval instars of Somatochlora kennedyi, a species he reared from overwintered eggs, is still the most detailed available for this genus.

Despite the extent and calibre of these studies of larvae, it is for his work on the systematics of adults that Walker is best known. His approach has been essentially the same as for the larvae: to elucidate refractory groups and species and, when describing new species, to construct or modernize keys for distinguishing their North American relatives. Two contributions in this field which are outstanding are his monographic revisions of the North American species of Aeshna (1912f) and Somatochlora (1925). It was particularly appropriate that the task of revising these two genera should have fallen to Walker, since in the Nearctic Region both may be said to have their centre of distribution in Canada. Both monographs follow the same arrangement, and both have been regarded as models of their kind since they first appeared. That on Aeshna was undertaken at the suggestion of E. B. Williamson, a friend and distinguished dragonfly worker from Indiana, with whom Walker corresponded regularly and for whom he named Somatochlora williamsoni, his first new species (1907).

Characteristically, the first publication resulting from the Aeshna revision was something immediately useful-a short key to the North American species (1908d). This contained eight new descriptions, including that of the Holarctic Aeshna subarctica, a species which had been collected (though not yet recognized) in Europe as well as in North America. In the monograph, published four years later, five of these eight forms retained specific status, two were seen as subspecies of the variable and wide-ranging Aeshna interrupta, and one was found to be identical with $A$. interrupta lineata. This monograph is an exceptionally penetrating analysis of a genus which had hitherto proved troublesome. By showing that, contrary to the then widely held belief, adults of Aeshna can be reliably distinguished by their colour pattern, Walker was able to correct the misconceptions of earlier workers and to recognize geographical variation for what it was. As 
Kennedy wrote in his description of Aeshna walkeri, this "beautiful monograph ... has opened the way for future students" (p. 588). In a preliminary taxonomic section terms are defined, as a basis for the structural comparisons which follow. This part alone offers an education to the student of dragonfly morphology. After showing the relationships of North American aeshnids to their Palaearctic counterparts, he recognizes generic groups and interprets their phylogeny, thus putting the genus Aeshna in its proper perspective. Much stimulating information is contained in the next section which deals with variation. Within Aeshna umbrosa he notes structural variation (in the dimensions of the third abdominal segment and the female anal appendages) which is correlated with geographical distribution and which he sees as an expression of the mean temperature of the environment during the growing season. Variations in colour, especially of the female, are also related to climate. After an extended section (twenty-six pages) devoted to the life history, keys are given for distinguishing the adults (sixteen species and six subspecies) and known larvae (eleven species and one subspecies). These are followed by detailed descriptions of each species, with remarks on its distribution in terms of Merriam's life zones and on its habits. The twenty-eight plates, six of which are in colour, provide a fitting and beautiful conclusion to this remarkable monograph. Reviewing it in 1912, Calvert ${ }^{2}$ wrote: "It is doubtful whether anyone hitherto has produced a work treating of so many aspects of a group of Odonata as this one does." In 1927 Cockerell $^{3}$ deemed it "one of the best studies ever made of a group of insects." And forty-two years later, after many more areas had been visited and specimens collected, Needham and Westfall (1954), ${ }^{4}$ in their Dragonflies of North America, could still recommend the monograph as being "the one indispensable work for further study of this genus."

Walker's second major revision, dealing with the North American species of Somatochlora, appeared in 1925. This genus, the largest in the Corduliidae, is entirely Holarctic and predominantly Canadian. With Aeshna it is found as far north as Odonata exist, and is most numerous in species and individuals in subarctic and subalpine

${ }^{1}$ Kennedy, C. H. 1917. Notes on the life history and ecology of the dragonflies (Odonata) of central California and Nevada. Proc. U.S. Nat. Mus. 52: 483-635.

${ }^{2}$ Calvert, P. P. 1912. Review. Ent. News 23: 283-286.

${ }^{3}$ Cockerell, T. D. A. 1927. Zoology of Colorado. University of Colorado, Boulder. $262 \mathrm{pp}$.

${ }^{4}$ Needham, J. G., and M. J. Westfall. 1954. Dragonflies of North America. University of California Press, Berkeley and Los Angeles. 615 pp. 
regions. If any genus of dragonfly is emblematic of Canada it is surely Somatochlora. These insects, Walker writes, are "shy denizens of the wilderness, being seen at their best in the northern coniferous forests and the mountains." Seldom abundant, even near their breeding places, these enchanting corduliids were naturally among the last to be systematically studied. Available to Walker were some 1,300 specimens (for the Aeshna work he had had about 1,720). This monograph follows the style of its predecessor and gives a detailed account of the twenty-one North American species then known. Of these Walker had field knowledge of fourteen, and was able to give larval descriptions of the same number; he had witnessed oviposition in nine. Five of the North American species were his own: Somatochlora williamsoni (1907), S. incurvata (1918a), S. kennedyi (1918a), S. georgiana, and S. whitehousei (1925). A novel feature of this monograph is the distribution maps, which record the known and predicted range for fourteen species, a natural product of Walker's interest in zoogeography. When systematic collections were later made in arctic and subarctic Canada (1943a, 1947, 1951b) the fulfilment of these predictions must have been gratifying for him. Another noteworthy item in this monograph is the recognition that there are two distinct types of ovipositor in Somatochlora, and that these are associated with correspondingly different patterns of behaviour. This discovery he amplified by an ingenious experiment designed to determine the significance of the intermittent moss-touching behaviour shown by ovipositing females of $S$. elongata and $S$. minor. In the section on variation he observes that the shape of the female abdomen changes with age in Somatochlora and Cordulia, a littleknown fact of considerable topical interest today. The thirty-five plates, which contain many beautiful ink and wash drawings (see Fig. 8 ), include photographs of habitats. This monograph, too, has become a classic in its field. Reviewing it in 1926, Calvert ${ }^{5}$ remarked that "few works in odonatological literature equal it in the detailed information it contains." And twenty-eight years later we find opinion of its worth unchanged, Needham and Westfall recommending it as "a work indispensable to anyone who would make further studies of this genus."

Other systematic revisions undertaken by Walker include the elucidation of the Sympetrum semicinctum complex (1951a), the recognition and description of the forms of Lestes disjunctus (1952b), and

${ }^{5}$ Calvert, P. P. 1926. Review. Ent. News 37: 90-92. 
an analysis of the North American species of Gomphus (sensu stricto) based on structure of the genitalia (1957a). This last, which he found necessary to undertake when preparing his book (1958), enabled him to offer a phylogenetic classification of this difficult group and of related subgenera. Either in the course of these revisions, or in separate publications, Walker has described fourteen new species (of Coenagrion, Gomphus, Aeshna, Macromia, Somatochlora, and Leucorrhinia) and thirteen subspecies (of Lestes, Aeshna, Staurophlebia, and Sympetrum). Noteworthy among the many redescriptions he has made is that of Coenagrion interrogatum (1915c), a species of Selys which Walker rediscovered at Nipigon, Ontario in 1913.

Arising from his taxonomic work were Walker's studies of the interlocking of male and female structures during the tandem and mating positions, a venture into functional morphology which offered scope for his acute powers of observation and his skill in drawing what he saw. In Argia moesta he observed (1913c) that, once in the tandem position, the male cannot release the female unless she permits it, and further, that interlocking of complementary structures is so precise that this alone could probably prevent interspecific crossing. In Aeshnidae he found the tandem bond to be even more complex and secure (1912f, 1915f), observing that these were the only dragonflies in which the male appendages were inserted on both the head and prothorax of the female. This refinement he considered to be correlated with their exceptionally vigorous and erratic tandem flight rather than with the need to achieve sexual isolation. Observation of mixed tandem pairs at the Timagami Forest Reserve in Ontario (1912f, p. 39) led him to regard the genitalia as the crucial barrier preventing interspecific crossing. "Several times pairs were observed which were not in coitu, the male simply grasping the head of the female by the abdominal appendages. Some of these pairs were flying with the bodies of both sexes extended after the manner of the damselflies (Coenagrionidae), no attempt at copulation being made. In others the abdomen of the female was seen to curve upward frequently toward the male accessory genitalia but without establishing a connection. While some or all of the partial unions may have taken place between different species, two positive cases of this kind were observed. A male of Ae. subarctica was taken with a female of $A e$. canadensis and a male of Ae. interrupta also with a female of canadensis." 
Outside systematics or morphology, most of Walker's publications are annotated fauna-lists for provinces or localities of special interest (e.g. Algonquin Park, 1906a; the Canadian Cordillera, 1927b; arctic and subarctic regions, 1943a, 1947, 1951b). These papers are always much more than mere lists. Notes on phenology and behaviour accompany the several species, and usually there is a concentrated introduciton in which the fauna is placed in zoogeographical perspective. The species are associated with their respective life zones, thus helping to characterize the area and permitting a soundly-based prediction to be made of the total fauna. Such treatment can be found in almost all his two dozen or so papers on local distribution and in his book. His paper on the Odonata of the Canadian Cordillera (1927b), for example, opens with an account of the area under consideration and the representation of the various families in it. Four faunistic elements are recognized and the species characterizing them are listed. The three life zones involved (Alpine, Canadian, and Transition) are described and the faunal richness of the last, which contains both boreal and austral species, he attributes to the cool summer (which allows the southward extension of boreal species) and the long flying season and mild winter (which allows the northward extension of austral species). "This peculiarity is forcibly illustrated in the case of two species, Somatochlora albicincta, a truly boreal form, and Pachydiplax longipennis, an austral species. Both species occur in Ontario as well as in British Columbia, but, whereas on Vancouver Island both may be found not only at the same locality but at the same pond, in Ontario the northern limit of $P$. longipennis is separated from the southern limit of $S$. albicincta by at least 200 miles."

Often in this informative introduction Walker gives a detailed account of the habitats at which the principal collections were made, and lists their dragonfly faunas. This he does in unusual detail in his account of the Odonata of Go Home Bay (1915g), an area where he had spent nearly a whole season in 1912, a rare luxury for him on a study visit. In this paper he defines three major categories of habitats, recognizes their subdivisions, lists the species associated with each, and illustrates typical sites by photographs. A phenological diagram compares the flight periods of thirty-nine species. Thus the paper provides an informative and disciplined account of the ecology of the local species.

From what has been said, it will be realized that any one of Walker's papers, whatever its principal theme, is liable to contain 
information of interest on ecology and behaviour. Hence to categorize his contributions in these areas would be difficult, if not unreal. Suffice it to say that there were few aspects of dragonfly biology on which he did not make some astute and useful observations. In his monographs and book can be found many references to such subjects as daily and seasonal patterns of emergence; the maturation period; feeding aggregations; aggressive display; courtship; mating sites; sexual recognition; oviposition behaviour; times of adult activity; and yearly fluctuations in numbers. His observations on these and allied topics make informative reading, and it is difficult to realize that some were written against the background of knowledge as it stood half a century ago. Some of these accounts, often quoted from his field notebook, have a vividness that is strangely compelling. The reader seems to share Walker's responses to the things he saw: his excitement at a discovery; his renewed delight at seeing DeGrassi Point each spring; his love of the wild and beautiful places he visited; and his affection for the dragonflies he came to know so well. There are few scientific writers who possess this magic touch-just as there are few who can transform disciplined drawings into things of dignity and beauty. Students of Odonata will always be grateful that Edmund Walker possessed both talents in such abundant measure.

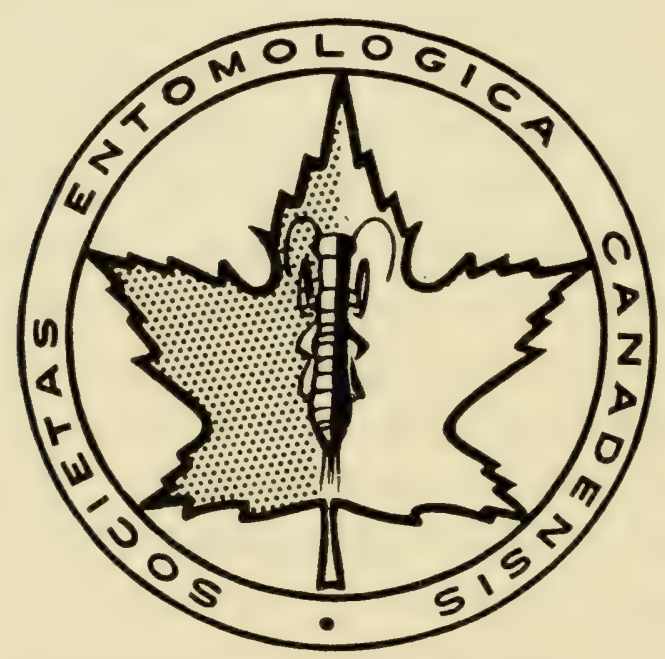

FIGURE 10. Emblem of the Entomological Society of Canada, with Grylloblatta campodeiformis Walker. 


\section{Impression of Delight}

\section{J. G. OUGHTON}

... These excursions have left a delightful impression on my mind. He was, on such occasions, in as good spirits as a boy, and laughed as heartily as a boy at the misadventures of those who chased the splendid swallow-tail butterflies across the broken and treacherous fens. He used to pause every now and then to lecture on some plant or other object; and something he could tell us on every insect, shell, or fossil collected, for he had attended to every branch of natural history. After our day's work we used to dine at some inn or house, and most jovial we then were. I believe all who joined these excursions will agree with me that they have left an enduring impression of delight on our minds.

Charles Darwin commenting on Professor Henslow, from The Life and Letters of Charles Darwin, edited by FRANCIS DARWIN

WHAT SHALL WE CALL HIM: scientist, field naturalist, or artist? The chief scholarly contributions of Dr. E. M. Walker are, of course, his entomological studies, which fall into two main groups: monographs and shorter papers dealing with the morphology, taxonomy, habits, life-history, and geographical distribution of Orthoptera and Odonata; and, arising from his studies on Grylloblatta, a broader attack on the evolution of orthopteroids. In addition to this large and connected body of work, he found time to report on some of the many other aspects of living things that have interested him. One group of papers gave, for the first time, information on the structure, life cycle, and habits of Wohlfahrtia vigil, a sarcophagid fly (1920b, 1922c, 1931c, 1937b). This species, on occasion, deposits its larvae on the exposed skin of human infants, causing lesions, but, fortunately for 
us, its usual host is the newborn of some other mammal. Two other papers of his $(1927 \mathrm{a}, 1928 \mathrm{a})$ treat the Canadian woodlice, one of several groups of small animals that have received little attention in our country. He was able to establish that the predominant woodlice of settled areas are not native, but introduced species. He took advantage of spare time at his summer cottage to prepare a faunal list of the land snails of that area (1917a). During another summer "holiday," this time in New Brunswick, he came to know the field birch, a form related to our more common white birch. On his return journey by rail, he was surprised to see a clump of the same species growing in the Thousand Islands region of Ontario. His note on this finding (1946) drew it to the attention of fellow naturalists of the Province.

The paragraph above could stand as a brief statement of the published work of E. M. Walker. It is the sort of memorandum that some distant student might prepare after poking through the library stacks. Although it is a record of achievements sufficient for the lifework of any one man, it fails to reveal the warmth of his personality, nor does it sufficiently exhibit the diversity of his talents.

His passion for patient and accurate observation was displayed early in life. As a very young boy, he became aware of the moon's cyclical changes. He recorded its phases by cutting out matching shapes of paper and pasting them on the window glass. The ability to discern differences, sometimes of great subtlety, was exercised in his studies concerned with taxonomy and morphology. It went hand in glove with another considerable skill: the delineation of form with pen, pencil, brush or chalk crayon. Add to this already formidable list of traits, a memory that seemed to hold forever anything which was part of his concern. Hence, when he described some point in his lectures, he deftly drew pictures which were both lively and accurate. In recalling the activities of some animal that he had observed, perhaps long ago, he would unconsciously mime the movements that were so vivid in his mind. The sounds and calls of many animals he noted with care and remembered. Many of them he could faithfully imitate.

Perhaps it is necessary for any man who has done so much in his field and has retained such a bulk of it in his mind, to insulate himself from the details of life that, for him, are irrelevant. Certainly, there were some things that E. M.'s otherwise superb memory did not attempt to hold-where he had put keys for the car, or even where 
he had left the car. To many, he must have seemed polite and formal, even distant, because he had little time for the fiddle-faddle that crowds our day-to-day life; but to those who shared his interests he gave himself completely. To a few others he may have seemed to be curt: he disliked sham and was not always successful in disguising his disapproval of it whether it was practised by the small or the mighty. Although the structural complexities of the living world engaged his interest, the workings of machines more intricate than a bicycle held no fascination for him. But bicycles he liked. He would discourse on their evolution from the bone-shaker and penny-farthing, comparing it with the development of animals, in that there was an early radiation and a later settling down of the perfected form.

Biologists have seldom turned their microscopes on themselves. There are very few studies dealing with the proper nurture of scientists. What determines that one person becomes a banker, lawyer, salesman, or biologist? In the case of E. M. Walker, there are many suggestive clues: a grandfather and father who had collected fossils; a liberal family circle, in which Japanese, European, and Canadian art could be discussed, along with Darwin's relatively new theory of evolution. He was not only given the freedom to explore, but encouraged to do so. He was favoured, too, in having contact with able naturalists of the day. Beyond these obvious points the argument is less certain. Did biologists of the taxonomic-morphological-naturalist school (are they a dying breed?) differ from other people in having a mind that formed lively pictures? Or again, why do so many naturalists have such an intense love, almost a reverence, for all living things-dogs, horses, violets, worms, and bugs?

Perhaps one should say that Dr. Walker is a naturalist in the great eighteenth- and nineteenth-century tradition: that is, one whose field of study was nature. There are, of course, dangers in trying to encompass so much; there is the risk of achieving great breadth but no depth. The scholarly atmosphere of the university and of his home, however, served to channel his efforts productively. Before ecology had become a recognized biological discipline he was an ecologist of the sort portrayed by Charles Elton three decades ago: "The ecologist should cultivate the habit of looking at animals from this point of view (that is, of considering the niche or role) as well as from the ordinary standpoints of appearance, names, affinities, and past history. When an ecologist says: 'There goes a badger,' he should include in 
his thoughts some definite ideas of the animal's place in the community to which it belongs, just as if he had said 'There goes the vicar.".

Although the theory or law of organic evolution grew out of natural history, its outcome was an emphasis on anatomy and systematics, which were the major points of view during Dr. Walker's undergraduate years. Later, genetics and ecology came to be tackled, although these two specialties were quite separate then and also apparently unrelated to the work of the biologists of the late nineteenth century. Now, with the understanding of the cell's workings gained by the physiologist and chemist, biology has swung full circle and returned once more to considering nature in its entirety but at a different level.

The writer remembers with pleasure the field trips taken with Dr. Walker along Ontario roads in (or rather, in spite of) various automobiles. Motor vehicles are inanimate and hence, according to some observers, are subject to the usual laws of physics and chemistry. Before jumping to such conclusions, one should consider the evidence gained from our field trips. One car that seemed to be very trustworthy in the city developed alarming convulsions when we reached the sparse regions of the northern Ottawa valley. Steam blew out of the radiator and the slightest mistreatment would throw it into a tantrum. Then there was a sporty little roadster which had a dickey seat in the rear for the storage of our gear. Unfortunately, we had great difficulty in opening this rear compartment. Just when the writer had started to develop skill in unlocking the dickey seat by jiggling the key and thumping on the metal, a mischievous locksmith pointed out that we were using the wrong key. A third and more modest vehicle of sworn reliability showed its true nature as soon as it shared our travels. It developed a long series of minor ailments, small coughs, sneezes, and sputterings. Very short-sightedly, too, it had brought no tools except a rusted screwdriver which it had cached under the hood. It is possible that cars and highways were not built to serve the naturalist in his pursuits or, to state the case from a more sensible point of view, a keen interest in natural history may disqualify a person as a driver on modern roads. After all, how could one keep his eyes on the road with the dragonflies flashing in the sunlight above the water? Soon after the car had come to an abrupt stop, a lithe and bearded figure could be seen in hot pursuit of the fleet dragons. The traffic snarl, caused in the interests of science, unwound itself: cars honked in protest as they passed us; the day settled down again for a time to the 
capture of the "white-banded mudhorses" and the colourful "tomatochlorides" (Somatochlora).

Walking with E. M. out-of-doors was like visiting one's home town; there was a feeling of familiarity and interdependence. The whirring and rasping noises of the insects, the flight habit exhibited by a damselfly or the changed habitat of cabbage butterflies and grackles took on meaning in his presence. In a sense, nature was his hometown, and he moved about in it in the same easy way as others might amidst the people and buildings and objects that they see every day.

As we drove from one collecting station in search of the next, we entertained ourselves in various fashions; there were imitations of the calls of animals: a three-part band of which two parts, whistling and humming, were supplied by E. M. simultaneously; recitations from Lewis Carroll; songs that had been music hall favourites of his youth; the compilation of a checklist of the pet names bestowed on cottages, of which "EEEE," "Dew Drop Inn," and "Dun Roamin" are the prototypes, and a critical survey, unpublished, of art found in rooming houses and restaurants. The murals painted on the "eatery" walls opposite us were enjoyed and digested with our food. What unlikely ships they showed: what neat and marcelled seas there were; and beyond, how troubled the mountains of indeterminate brown seemed. One painting, I remember, far outreached all others in the boldness of its artist's intention. In its foreground sat a grey, oedematous female. On each side, an angel suffering from overweight and from shortness of wing, was trying desperately to stay aloft. Dr. Walker could not keep his eyes off this prodigy as he talked to the landlady. She gave us the one note of elucidation which can be passed on to future students of such indigenous art. On seeing Dr. Walker's obvious interest, she explained proudly: "My daughter."

At night, after the day's catch had been safely papered and packed away, he would sit and talk of his trips on the North Shore with Napoleon Comeau or of the epic dash to the West with Taka Kurata and R. B. Thomson in the latter's Ford, or of O'Brien and other early Canadian painters he had known through his father. Towards the end of the evening, if coaxed a bit, he would beat out a few xylophone solos by tapping on a lead pencil held against his teeth, varying the pitch by changing the volume of his mouth cavity.

As a teacher, Dr. Walker brought fervour and an encyclopaedic command of his subject to his students. He expected diligence and uncompromising accuracy of them. His one-term course in the zoology 
of the invertebrates was not long enough to cover all of the things he considered to be of importance. It was almost the last class and there were still some animal groups unbroached, he sadly confessed. But in the next class he was jubilant. His old friend, R. B., the botanist, had relinquished some of his time so that invertebrate zoology might go on. Later, we found out that this attrition of botany was almost an annual event.

The writer had the good fortune to assist Dr. Walker with the laboratory classes offered to pass-course students. The room itself, far from ideal, was the long one on the second floor of the old Biology Building. To the north, one could see the parking quadrangle, part of the medical building and heating plant and Queen's Park Crescent. On the south, a group of rooms, from which one could hear the muffled arguments and laughter of postgraduate students. At either end, there was a doorway through which passed the traffic of the building. In addition, the west end contained the arched entrance to the curving staircase that led below to the teaching museum. In the arch, one could see the dusty, plaster busts of men of the past. As I paced up and down in this classroom, I wondered how a knowledge of the trematode reproductive system or of the annelid excretory tubule would contribute to the education of a person who might later become a teacher of English or a businessman. Of course, because of my inexperience, I failed to grasp the central point. The answer came later from a social worker who had been a member of this class in my day: "Although we could not always understand the details he presented, he managed to convey something of the vitality, excitement, and importance of biology." 


\section{Publications of E.M. Walker}

\section{LIBRARY STAFF, ROYAL ONTARIO MUSEUM}

THIS LIST DOES NOT include some fifty book reviews and short notes, largely unsigned, and published mainly in the Canadian Entomologist from 1910 to 1920, during Dr. Walker's term as editor.

1897 Occurrence of Schistocerca americana (Drury) at Toronto. Canad. Ent., vol. 29, no. 4, p. 89.

1898a A new grasshopper from Ontario. Canad. Ent., vol. 30, no. 4, pp. 90-92.

1898b Notes on some Ontario Acridiidae. Part I. Canad. Ent., vol. 30 , no. 5, pp. 122-126.

1898c A new alpine grasshopper from western Canada. Canad. Ent., vol. 30, no. 8, pp. 197-199.

1898d Notes on some Ontario Acridiidae. Part II. Canad. Ent., vol. 30 , no. 10 , pp. 258-263.

1899 Notes on some Ontario Acridiidae. Part III. Canad. Ent., vol. 31, no. 2, pp. 29-36.

1901 Notes on some Ontario Acridiidae. Part IV. Canad. Ent., vol. 33, no. 1, pp. 20-23.

1902a A collecting trip in south-western Ontario. 32nd Ann. Rept. Ent. Soc. Ont., for 1901, pp. 85-90.

1902b Entomological record: Orthoptera. 32nd Ann. Rept. Ent. Soc. Ont., for 1901, pp. 108-109.

1902c The Canadian species of Trimerotropis. Canad. Ent., vol. 34, no. 1, pp. 1-11.

1902d A preliminary list of the Acridiidae of Ontario. Canad. Ent., vol. 34 , no. 10 , pp. 251-258. 
1903a Reports on insects of the year: Division No. 3-Toronto. 33rd Ann. Rept. Ent. Soc. Ont., for 1902, pp. 39-41.

1903b Entomological record: Orthoptera. 33rd Ann. Rept. Ent. Soc. Ont., for 1902, p. 98.

1903c The genus Podisma in eastern North America. Canad. Ent., vol. 35 , no. 11 , pp. 295-302.

1904a The crickets of Ontario. Canad. Ent., vol. 36, no. 5, pp. 142-144; vol. 36 , no. 7, pp. 181-188; vol. 36, no. 9, pp. 249-255.

1904b Notes on the Locustidae of Ontario. Canad. Ent., vol. 36, no. 11 , pp. 325-330; vol. 36 , no. 12 , pp. 337-341.

1904c The nymph of Gomphus furcifer, Hagen. Canad. Ent., vol. 36 , no. 12 , pp. 358-359.

1904d Entomological record: Orthoptera. 34th Ann. Rept. Ent. Soc. Ont., for 1903, p. 97.

1905 Notes on the Locustidae of Ontario. Canad. Ent., vol. 37, no. 2, pp. 34-38; vol. 37, no. 4, pp. 113-119.

1906a Orthoptera and Odonata from Algonquin Park, Ont. 36th Ann. Rept. Ent. Soc. Ont., for 1905, pp. 64-70.

1906b Entomological record: Odonata. 36th Ann. Rept. Ent. Soc. Ont., for 1905, pp. 103-104.

1906c Records in Orthoptera from the Canadian Northwest. Canad. Ent., vol. 38, no. 2, pp. 55-59.

1906d A first list of Ontario Odonata. Canad. Ent., vol. 38, no. 4, pp. 105-110; vol. 38, no. 5, pp. 149-154.

1907 A new Somatochlora, with a note on the species known from Ontario. Canad. Ent., vol. 39. no. 3, pp. 69-74.

1908a Collecting and rearing dragon-flies at the Georgian Bay Biological Station. 38th Ann. Rept. Ent. Soc. Ont., for 1907, pp. 43-50.

1908b Entomological record: Odonata. 38th Ann. Rept. Ent. Soc. Ont., for 1907, pp. 131-132.

1908c The dragon-flies (Odonata) of the Ottawa district. Ottawa Nat., vol. 22 , no. 1 , pp. 16-23; vol. 22 , no. 3, pp. 49-64.

1908d A key to the North American species of Aeshna found north 
of Mexico. Canad. Ent., vol. 40, no. 11, pp. 377-391; vol. 40 , no. 12 , pp. $450-451$.

1909a On the Orthoptera of northern Ontario. Canad. Ent., vol. 41, no. 5 , pp. 137-144; vol. 41 , no. 6 , pp. 173-178; vol. 41, no. 7, pp. 205-212.

1909b Entomological record: Orthoptera; Odonata. 39th Ann. Rept. Ent. Soc. Ont., for 1908, pp. 113-114.

1910a Correction [to Key to the North American species of Aeshna found north of Mexico]. Canad. Ent., vol. 42, no. 1, p. 24.

$1910 \mathrm{~b}$ The Orthoptera of western Canada. Canad. Ent., vol. 42, no. 8, pp. 269-276; vol. 42, no. 9, pp. 293-300; vol. 42, no. 10, pp. 333-340; vol. 42, no. 11, pp. 351-356.

1910c Entomological record: Odonata. 40th Ann. Rept. Ent. Soc. Ont., for 1909, pp. 125-127.

1911a On the habits and stridulation of Idionotus brevipes Caudell, and other notes on Orthoptera. Canad. Ent., vol. 43, no. 9, pp. 303-304.

1911b Entomological record: Orthoptera; Odonata. 41st Ann. Rept. Ent. Soc. Ont., for 1910, pp. 119-120.

1912a Annual address of the President. 42nd Ann. Rept. Ent. Soc. Ont., for 1911, pp. 51-55.

$1912 \mathrm{~b}$ Some injurious forest insects at DeGrassi Point, Lake Simcoe. 42nd Ann. Rept. Ent. Soc. Ont., for 1911, pp. 55-63.

1912c Entomological record: Odonata. 42nd Ann. Rept. Ent. Soc. Ont., for 1911, pp. 111-112.

1912d The Blattidae of Ontario. Canad. Ent., vol. 44, no. 6, pp. 171-172.

1912e The Odonata of the Prairie Provinces of Canada. Canad. Ent., vol. 44, no. 9, pp. 253-266.

$1912 \mathrm{f}$ The North American dragon-flies of the genus Aeshna. Univ. Toronto Studies, Biol. Ser., no. 11, 213 pp.

$1912 \mathrm{~g}$ Translation into English: A revision of my "Nordamerikanische Hydrachniden" by F. Koenike. Trans. Can. Inst., for 1911, vol. 9, pt. 3, pp. 281-296.

1913a Annual address of the President-The faunal zones of 
Canada. 43rd Ann. Rept. Ent. Soc. Ont., for 1912, pp. 26-33.

1913b New nymphs of Canadian Odonata. Canad. Ent., vol. 45, no. 6, pp. 161-170.

1913c Mutual adaptation of the sexes in Argia moesta putrida. Canad. Ent., vol. 45, no. 9, pp. 277-279.

1913d Insects and their allies. In The Natural History of the Toronto Region, Ontario, Canada. Edited by J. H. Faull. Toronto, published by the Canadian Institute, 1913, chap. 22, pp. 295-403.

1914a A new species of Orthoptera, forming a new genus and family. Canad. Ent., vol. 46, no. 3, pp. 93-99.

1914b Bibliography of Canadian Zoology, 1913 (exclusive of entomology). Trans. Roy. Soc. Can., Ser. 3, Sec. IV, vol. 8, pp. 271-285.

1914c The known nymphs of the Canadian species of Lestes (Odonata). Canad. Ent., vol. 46, no. 6, pp. 189-200.

1914d New and little-known nymphs of Canadian Odonata. Canad. Ent., vol. 46, no. 10, pp. 349-357; vol. 46, no. 11, pp. 369377.

$1914 \mathrm{e}$ [Species of Orthoptera described by E. M. Walker for which type specimens are deposited in the Royal Ontario Museum.] Canad. Ent., vol. 46, no. 10, p. 368.

1915a The occurrence of Mantis religiosa L. in Canada. Canad. Ent., vol. 47, no. 4, p. 135.

1915b Bibliography of Canadian Zoology, 1914 (exclusive of entomology). Trans. Roy. Soc. Can., Ser. 3, Sec. IV, vol. 9, pp. 307-318.

1915c The re-discovery of Agrion interrogatum, Selys. Canad. Ent., vol. 47, no. 6, pp. 174-181.

1915d Notes on a collection of Orthoptera from Prince Edward Island and the Magdalen Islands, Que. Canad. Ent., vol. 47, no. 10, pp. 339-344.

1915e Aeshna umbrosa umbrosa Walk. in Newfoundland. Canad. Ent., vol. 47, no. 12, p. 386. 
$1915 \mathrm{f}$ Notes on Staurophlebia reticulata Burm. Canad. Ent., vol. 47 , no. 12 , pp. 387-395.

$1915 \mathrm{~g}$ Notes on the Odonata of the vicinity of Go Home Bay, Georgian Bay, Ontario. Contr. to Can. Biology, Suppl. to 47th Ann. Rept. Dept. Marine and Fisheries, Fisheries Branch, Ottawa, pp. 53-94.

1916a Bibliography of Canadian Zoology, 1915 (exclusive of entomology). Trans. Roy. Soc. Can., Ser. 3, Sec. IV, vol. 10, pp. 201-215.

$1916 \mathrm{~b}$ The nymphs of Enallagma cyathigerum and $E$. calverti. Canad. Ent., vol. 48, no. 6, pp. 192-196.

1916c Popular and practical entomology. A few days in Newfoundland. Canad. Ent., vol. 48, no. 7, pp. 217-221; vol. 48, no. 8, pp. 257-261.

1916d A curious trap for dragonflies. Canad. Ent., vol. 48, no. 9, pp. 314-315.

1916e The nymphs of the North American species of Leucorrhinia. Canad. Ent., vol. 48, no. 12, pp. 414-422.

1917a Notes on the land Mollusca of DeGrassi Point, Lake Simcoe, and other Ontario localities. Ottawa Nat., vol. 31, no. 2, pp. 17-22; vol. 31, no. 3/4, pp. 40-45.

$1917 \mathrm{~b}$ Some dragonflies from Prince Edward Island. Canad. Ent., vol. 49, no. 4, pp. 117-119.

$1917 \mathrm{c}$ Seasonal irregularities in the occurrence of dragonflies. Canad. Ent., vol. 49, no. 5, pp. 171-178.

1917d The known nymphs of the North American species of Sympetrum (Odonata). Canad. Ent., vol. 49, no. 12, pp. 409-418.

1918a On the American representatives of Somatochlora arctica with descriptions of two new species. (Odonata). Canad. Ent., vol. 50, no. 11, pp. 365-375.

1918b Note on Agrion aequabile hudsonicum (Hagen). Canad. Ent., vol. 50, no. 12, pp. 410-411.

1919a On the male and immature state of Grylloblatta campodeiformis Walker. Canad. Ent., vol. 51, no. 6, 7, pp. 131-139. 
1919b The terminal abdominal structures of orthopteroid insects: a phylogenetic study. Introduction; Part I. The abdominal structures of the female. Ann. Ent. Soc. Amer., vol. 12, no. 4, pp. 267-325.

1919c Note on Mr. Hebard's article: Canad. Ent., vol. 51, no. 12, p. 279.

1920a The life cycle of orthopteroid orders. In Symposium on "The life cycle in insects." Ann. Ent. Soc. Amer., vol. 13, no. 2, pp. 137-141.

$1920 \mathrm{~b}$ Wohlfahrtia vigil (Walker) as a human parasite (DipteraSarcophagidae). J. Parasitology, vol. 7, no. 1, pp. 1-7.

1921 The nymph and breeding place of Aeshna sitchensis Hagen (Odonata). Canad. Ent., vol. 53, no. 10, pp. 221-226.

1922a Orthoptera collected in the Canadian Arctic. Rept. Can. Arctic Exped. 1913-1918, Vol. 3: Insects. Part J: Orthoptera, for 1920, pp. 3J-4J.

1922b The terminal structures of orthopteroid insects: a phylogenetic study. Part II. The terminal abdominal structures of the male. Ann. Ent. Soc. Amer., vol. 15, no. 1, pp. 1-87.

1922c Some cases of cutaneous myiasis, with notes on the larvae of Wohlfahrtia vigil (Walker). J. Parasitology, vol. 9, no. 1, pp. 1-5.

1923 Notes on the Odonata of Godbout, Quebec. Canad. Ent., vol. 55, no. 1, pp. 5-12.

1924 The Odonata of the Thunder Bay District, Ontario. Canad. Ent., vol. 56, no. 7, pp. 170-176; vol. 56, no. 8, pp. 182 189.

1925 The North American dragonflies of the genus Somatochlora. Univ. Toronto Studies, Biol. Ser., no. 26, 202 pp.

1927a The woodlice or Oniscoidea of Canada (Crustacea, Isopoda). Canad. Fld. Nat., vol. 41, no. 8, pp. 173-179.

1927b The Odonata of the Canadian Cordillera. Prov. Mus. Nat. Hist., B.C., 1927, 16 pp.

1928a The woodlice or Oniscoidea of Canada-additions and corrections. Canad. Fld. Nat., vol. 42, no. 2, pp. 46-47. 
1928b The nymphs of the Stylurus group of the genus Gomphus with notes on the distribution of this group in Canada (Odonata). Canad. Ent., vol. 60, no. 4, pp. 79-88.

1928c The Odonata (dragonflies) of the Lake Abitibi region. In A faunal investigation of the Lake Abitibi region, Ontario. Univ. Toronto Studies, Biol. Ser., no. 32, pp. 37-44.

1931a On the clypeus and labium of primitive insects. Canad. Ent., vol. 63, no. 4, pp. 75-81.

1931b On the anatomy of Grylloblatta campodeiformis Walker. 1. Exoskeleton and musculature of the head. Ann. Ent. Soc. Amer., vol. 24, no. 3, pp. 519-536.

1931c Cutaneous myiasis in Canada. Canad. Publ. Hlth. J., vol. 22, no. 10 , pp. 504-508.

1932a Prognathism and hypognathism in insects. Canad. Ent., vol. 64 , no. 10 , pp. $223-229$.

1932b The nymph of Gomphus quadricolor Walsh (Odonata). Canad. Ent., vol. 64, no. 12, pp. 270-273.

1932c The Odonata (dragonflies) of Lake Nipissing. Univ. Toronto Studies, Biol. Ser., no. 36, pp. 225-246; Publ. Ont. Fish. Res. Lab., no. 48.

1933a The Odonata of the Maritime Provinces. Proc. Nova Scotian Inst. Sci., vol. 18, pt. 3, pp. 106-128.

1933b The Odonata of Manitoba. Canad. Ent., vol. 65, no. 3, pp. 57-72.

1933c On the anatomy of Grylloblatta campodeiformis Walker. 2. Comparisons of head with those of other orthopteroid insects. Ann. Ent. Soc. Amer., vol. 26, no. 2, pp. 309-344.

1933d The nymphs of the Canadian species of Ophiogomphus (Odonata, Gomphidae). Canad. Ent., vol. 65, no. 10, pp. 217-229.

1934a A preliminary list of the insects of the Province of Quebec. Part IV, the Odonata. 26th Rept. Que. Soc. Protection of Plants. Suppl. 12 pp. [republished in 27th Rept., 1935, pp. 96-105.]

1934b The nymphs of Aeschna juncea L. and $A$. subarctica Wlk. Canad. Ent., vol. 66, no. 12, pp. 267-274. 
1937a A new Macromia from British Columbia (Odon. Corduliidae). Canad. Ent., vol. 69, no. 1, pp. 5-13.

1937b The larval stages of Wohlfahrtia vigil (Walker). J. Parasitology, vol. 23, no. 2, pp. 163-174.

1937c Presidential address-Grylloblatta, a living fossil. Trans. Roy. Soc. Can., Ser. 3, Sec. V, vol. 31, pp. 1-10.

1938a With W. E. Ricker. Notes on Odonata from the vicinity of Cultus Lake, B.C. Canad. Ent., vol. 70, no. 7, pp. 144-151.

1938 b On the anatomy of Grylloblatta campodeiformis Walker. 3. Exoskeleton and musculature of the neck and thorax. Ann. Ent. Soc. Amer., vol. 31, no. 4, pp. 588-640.

1940a Odonata from the Patricia portion of the Kenora District of Ontario with description of a new species of Leucorrhinia. Canad. Ent., vol. 72, no. 1, pp. 4-15.

$1940 \mathrm{~b}$ With F. A. Urquhart. New records and notes of Orthoptera in Ontario. Canad. Ent., vol. 72, no. 1, pp. 15-19.

1940c A preliminary list of the Odonata of Saskatchewan. Canad. Ent., vol 72, no. 2, pp. 26-35.

1940d A new Gomphus from Louisiana (Odonata, Gomphidae). Ent. News, vol. 51, no. 7, pp. 194-196.

1941a New records of Odonata from Manitoba. Canad. Ent., vol. 73, no. 2, pp. 35-36.

1941b List of the Odonata of Ontario with distributional and seasonal data. Trans. Roy. Canad. Inst. vol. 23, pt. 2, no. 50, pp. 201-265.

1941c Descriptions of two new nymphs. In British Columbia dragonflies (Odonata), with notes on distribution and habits, by F. C. Whitehouse. Amer. Midl. Nat., vol. 26, no. 3, pp. 488-557.

1941d The nymph of Somatochlora walshii Scudder. Canad. Ent., vol. 73, no. 11, pp. 203-205.

1941e The nymph of Aeschna verticalis Hagen. Canad. Ent., vol. 73 , no. 12, pp. 229-231.

1942a The female of Leucorrhinia patricia Walker, with further notes on the male. Canad. Ent., vol. 74, no. 4, pp. 74-75. 
$1942 \mathrm{~b}$ Additions to the list of Odonata of the Maritime Provinces. Proc. Nova Scotian Inst. Sci., vol. 20, no. 4, pp. 159-176.

1943a The Subarctic Odonata of North America. Canad. Ent. vol. 75 , no. 5 , pp. $79-90$.

$1943 \mathrm{~b}$ On the anatomy of Grylloblatta campodeiformis Walker. 4. Exoskeleton and musculature of the abdomen. Ann. Ent. Soc. Amer., vol. 36, no. 4, pp. 681-706.

1944 The nymphs of Enallagma clausum Morse and E. boreale Selys. Canad. Ent., vol. 76, no. 12, pp. 233-237.

1946 With W. S. Fox. Field Birch in Ontario (Betula populifolia Marsh). Canad. Fld. Nat., vol. 60, no. 4, pp. 90-91.

1947 Further notes on the Subarctic Odonata of North America. Canad. Ent., vol. 79, no. 4, pp. 62-67.

1949 On the anatomy of Grylloblatta campodeiformis Walker. 5. The organs of digestion. Canad. J. Res., vol. 27, Sec. D, no. 6, pp. 309-344.

1950a Notes on some Odonata from the Kenora and Rainy River Districts, Ontario. Canad. Ent., vol. 82, no. 1, pp. 16-21.

1950b Francis J. A. Morris (1869-1949). Canad. Fld. Nat., vol. 64, no. 4, pp. 150-152.

1951a Sympetrum semicinctum (Say) and its nearest allies (Odonata). Ent. News, vol. 62, no. 5, pp. 153-163.

1951b The Odonata of the Northern Insect Survey. Canad. Ent., vol. 83 , no. 10 , pp. 269-278.

1952a New or noteworthy records of Canadian Odonata. Canad. Ent., vol. 84, no. 5, pp. 125-130.

1952b The Lestes disjunctus and forcipatus complex (Odonata: Lestidae). Trans. Amer. Ent. Soc., vol. 78, pp. 59-74.

1953 The Odonata of Canada and Alaska. Vol. 1. Pt. I: General; Pt. II: The Zygoptera-Damselflies. Univ. of Toronto Press. $292 \mathrm{pp}$.

1956 Grylloblattaria. In Taxonomist's glossary of genitalia in insects. Edited by S. L. Tuxen. Ejnar Munksgaard, Copenhagen. pp. 47-49.

1957a The affinities of the North American species of Gomphus as 
revealed by the genitalia (Odonata, Gomphidae). Contrib. Roy. Ont. Mus., Div. Zool. and Palaeont., no. 46, 24 pp.

$1957 \mathrm{~b}$ Changes in the insect fauna of Ontario (with special reference to the Orthoptera). In Changes in the Fauna of Ontario. Edited by F. A. Urquhart. Univ. of Toronto Press for Roy. Ont. Mus. Div. Zool. and Palaeont. pp. 4-12.

1958 The Odonata of Canada and Alaska. Vol. 2. Pt. III: The Anisoptera-Four Families. Univ. of Toronto Press. 318 pp.

1961 With C. H. Kennedy. Dragonfly. In Encyclopaedia Britannica, vol. 7, pp. 570-572.

1966 On the generic status of Tetragoneuria and Epicordulia (Odonata: Corduliidae). Canad. Ent. In press. 



(c) 14 . 


\section{LIBRARY}

ROYAL ONTARIO MUSEUM 

